5
574.5 $\mathrm{F} 26$
1975

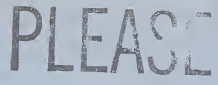

RETITIN

BULL MOUNTAINS COAL FIELD STUDY

Progress RePoRt 1975

REsearch Conducted by:

MONTANA DEPARTMENT OF FISH AND GAME

EnVironment and InFormation Division

AND

CONSOLIDATION COAL COMPANY
SEP 91975

\section{STATE DOCUMENTS}

BTATE DOCUMENTS COLLECTHON

\section{JUL $8 \quad 1980$}

MONTANA STATE LIBRARY

930 E Lyndale Ave.

Holena, Montana 59601

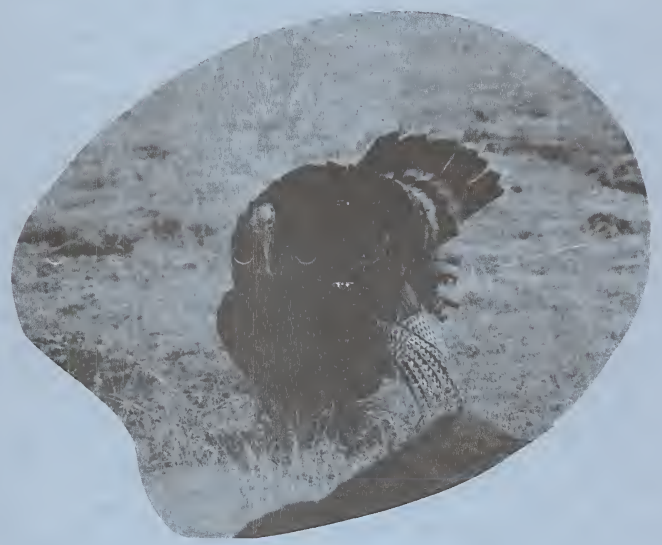

Prepared by: Gary l. Dusek, Environmental Planning Ecologist, ROUNDUP AND

Steven A. McCann, Research Assistant for Nongame MAMmALS, ROUNDUP 
BAIE WISE

MSE AUG 251976

MST OCT 26:77
MONTANA STATE LIBRARY s 574.5 F2b 1975 c.1 Dusek

Buil Mountsins coal fleid study sprogres

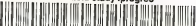

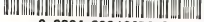

30864000193733 
List of Tables

List of Figures

Introduction . . . . . . . . . . . . . . 1

Study Area ....................... . . . . 1

Location ................... . . . . . . .

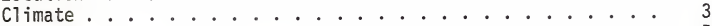

Vegetation ....................... 5

Phases of Study ................... . . . 5

General Wildlife Ecology Study ............. 5

Mule Deer ................ . . 5

Distribution and Range Use ......... 5

Movements ............ . . 7

Group Characteristics . . . . . . . . 10

Use of Vegetation Types ......... 11

Relation to Timber......... 13

Use of Slopes ................ 13

Use of Exposures ............ 15

Food Habits . . . . . . . . . . . . . 15

Fal1 .................. 15

Winter............. 18

Population Characteristics . . . . . . . 18

Elk .................. 20 20

Distribution and Range Use ......... 20 20

Distribution and Movements . . . . . . 20

Group Characteristics ... . . . . . . . 24

Use of Vegetation Types ......... 27 27

Relation to Timber. . . . . . . . . . 27

Use of Slopes ............. . . . . . 30

Use of Exposures . . . . . . . . . . . 32

Population Characteristics ......... . 32

Turkeys ................. . . . . 34

Distribution and Range Use . . . . . . . . 34

Distribution .......... . . . . . 34

Flocking Characteristics ........ . 35

Use of Vegetation Types ........ . . 35

Relation to Timber.......... 38

Use of Slopes . . . . . . . . . . . . 39

Population Characteristics ........ 39

Pronghorn ...................... . . . 41

Distribution ................. 41

Population Characteristics ......... 41

Rest-Rotation Grazing Study .............. 42

Rest-Rotation Grazing System . . . . . . . . . . 42

Grazing Management for Remainder of Ranch . . . . . . 44

Management Benefits ............... 44

Revegetation Studies . . . . . . . . . . . . . 45

Consol's Test Pit .............. . . . . 45

Vegetational Analysis........... . 46

Soil Mixture . . . . . . . . . . . 46 

Page

Gradient ............ . . 50

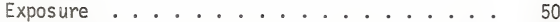

Use by Wildlife .............. 52

Game Species ................. 52

Nongame Mammals .......... 52

Square Deal Pit............... 63

Vegetational Analysis .......... 63

Use by Nongame Mamma 1s . . . . . . . . . 64

Nongame Mammal Inventory . . . . . . . . . . . . . . 64

Deer Mouse . . . . . . . . . . . . . 64

Population Study ............ 64

Habitat Preference . . . . . . . . . 64

Food Habits . . . . . . . . . . . 69

Meadow Voles ................. . 69

Habitat Preference . . . . . . . . . 69

Food Habits . . . . . . . . . . . 69

Coyotes .................... 69

Red Fox .................. 69

Raccoon ................ 73

Bobcat ................. . . 73

Badger ................ . . . 73

Summary and Discussion .............. 73

Literature Cited .................. 79

Appendix ........................ 81

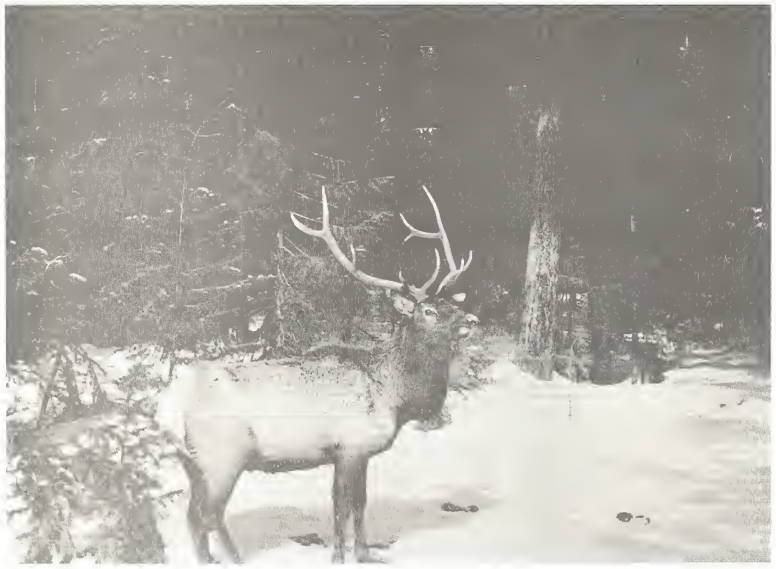


1. Climatological data for Roundup, Montana covering the period January 1972 to February 1975 . . . . . . . . . . .

2. Capture and relocation data for 27 mule deer captured and individual7y marked from January 1973 to February 1975 . . .

3. Seasonal use of vegetation types and subtypes by mule deer as determined by 1,892 ground and aerial observations during the

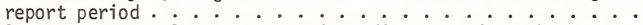

4. Occurrence of mule deer at various distances from the nearest stand of timber, determined from 1,892 ground and aerial ob-

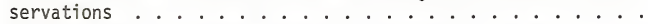

5. Seasonal use of various topographical features by mule deer as determined from 1,892 ground and aerial observations during the report period................

6. Seasonal use of gradients by mule deer during the report period

Page

7. Seasonal use of eight exposures by mule deer as determined from 692 ground and aerial observations during the report period .

8. Fall and winter food habits of mule deer as determined from examination of rumen samples and feeding sites ......

9. Browse utilization data for fall and winter browse species at four locations . . . . . . . . . .

10. Population characteristics of mule deer as determined from 1,891 ground and aerial observations from March 1974 to

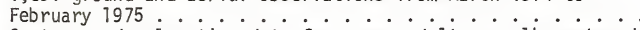

11. Capture and relocation data for seven aduit cow el $k$ captured and individually marked during February 1974 and January 1975

12. Seasonal use of vegetation types and subtypes by elk as determined from 1,060 ground and aerial observations during

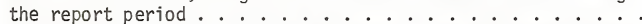

13. Occurrence of elk at various distances from the nearest stand of timber as determined from 1,060 ground and aerial observations during the report period ...........

14. Seasonal use of various topographical features by elk as determined from 1,060 ground and aerial observations during

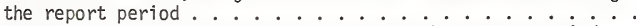

15. Seasonal use of gradients by eik during the report period. .

16. Seasonal use of each of eight exposures by elk as determined from 359 ground and aerial observations during the report period 32

17. Population characteristics of elk as determined from 322 ground and aerial observations during summer and fall $1974 \ldots .$.

18. Seasonal flocking habits of turkeys based on 545 observations of turkeys during the report period . . . . . . . . .

19. Seasonal use of vegetation types and subtypes by turkeys as determined from 545 ground and aerial observations during the

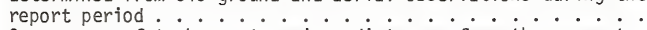

20. Occurrence of turkeys at various distances from the nearest stand of timber as determined from 499 ground and aerial observations during the report period . . . . . . . . . .

21. Seasonal use of the various topographical features by turkeys as determined from 545 ground and aerial observations during the report period ............... 

Table

Page

22. Seasonal use of gradients by turkeys during the report period 40

23. Population characteristics of turkeys during the period July-

September 1974 based on 130 observations ......... 40

24. Population characteristics of pronghorn as determined from 164 aerial observations in hunting district 540 during July $1974 \quad 42$

25. Schedule of grazing treatments for two three-pasture restrotation allotments for a 3-year cycle ..........

26. Constancy, canopy coverage and frequency of $10 \mathrm{w}$-growing vegetation on various types of soil on spoils material as determined by examination of $202 \times 5$ decimeter plots on each of 19 sites

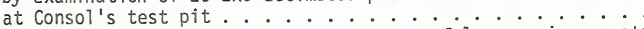

27. Constancy, canopy coverage and frequency of low-growing vegetation on various classes of gradient on spoils material as determined by examination of $202 \times 5$ decimeter plots on each of 19 sites at Consol's test pit. . . . . . . . . . . .

28. Constancy, canopy coverage and frequency of low-growing vegetation on northerly and southerly exposures on spoils material as determined by examination of $202 \times 5$ decimeter plots at each of 14 sites at Consol's test pit........

29. Home range data for deer mice at Consol's test pit. . . . . .

30. Deer mouse stomach analysis during summer and winter combined, Musselshel1 County ................. 60

31. Home range data for meadow voles at Consol's test pit . . . 61

32. Meadow vole stomach analysis during summer and winter combined, Musselshel1 County................ 61

33. Use of four soil types by nongame mamals at Consol's test pit 62

34. Constancy, canopy coverage and frequency of low-growing vegetation on a gently sloping southeast exposure as determined by examination of $202 \times 5$ decimeter plots at each of three sites at the Square Deal Mine

36. Coyote stomach analysis in Musselshe11 County during the winters of 1973-74 and 1974-75 ............. . . 70

37. Red fox stomach analysis in the Bull Mountains area during winter. . . . . . . . . . . 72

38. Raccoon stomach analysis in the Bull Mountains during winter 74

39. Bobcat stomach analys is in the Bull Mountains during winter . 75

40. Badger stomach analysis in the Bull Mountains during winter . 76

41. Data from red fox specimens collected in the Bull Mountains . 82

42. Data from raccoon specimens collected in the Bull Mountains . 82

43. Data from bobcat specimens . . . . . . . . . . . 83

44. Data from badger specimens .............. 83

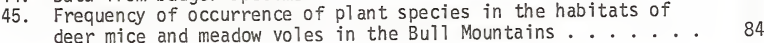



1. Bull Mountains study area ................ . . 2

2. Seasonal distribution of mule deer in the Bul1 Mountains during the report period ending February 28, 1975. Each data point represents the occurrence of deer in an area during a

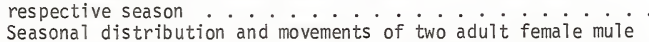
deer captured during January 1973 in the Fattig Creek drainage 9

4. Seasonal distribution of all elk observed in the Bull Mountains during the report period ending February 28, 1975. . . . . 22

5. Seasonal distribution and movements of adult cow (1) during the report period ending February 28, 1975 . . . . . . . 25

6. Seasonal distribution and movements of adult cow (2) during the report period ending February 28, 1975 . . . . . . . 26

7. Treatment pastures on Consol's ranch (left) and the grazing schedule for the first year of the rest-rotation grazing system (right)................... 43

8. Respective areas, soit mixtures and the location of 19 permanent vegetational analysis sites at Consol's test pit. . 47

9. Changes in cover of bare ground, 1itter, grasses and forbs on various soil mixtures at Consol's test pit from 1972 to $1974 \quad 49$

10. Changes in cover of bare ground, litter, grasses and forbs on various gradients at Consol's test pit from 1972 to 1974 . . 53

11. Changes in cover of bare ground, litter, grasses and forbs by aspect from 1972 to 1974 . . . . . . . . . . . . 55

12. Summer census 7 ines (lettered) and winter study areas (numbered)............................. 57

13. Deer mouse population trends at Consol's test pit . . . . . 58

14. Census lines at the Square Deal Mine (lettered). . . . . . . 65

15. Deer mouse population trends at the Square DeaT Mine . . . . 66

16. Population trends of deer mice in Musselshell County since $1970 \quad 65$

17. Trap sites during 1974-75 ............. . . 85 



\section{INTRODUCTION}

When the Bull Mountains Coal Field Study was initiated during January 1972, large-scale surface mining and exporting of coal from the area appeared imminent. During August 1971, Consolidation Coal Company (Consol) stripped overburden from approximately 6 acres overlying the Mammoth-Rehder coal seam, and approximately 39,000 tons of coal were extracted and shipped to the Chicago, Illinois area for a test of burning qualities. The area was subsequently graded and seeded with the intention, as expressed in the reclamation plan, of restoring the area to pasture which was the principal use prior to the operation. Consol did some additional revegetation work at the test pit during the fall of 1974, but has not been actively engaged in any mining activity in the Bull Mountains since the test shipment was mined. The two active mines in the area, both of which are surface operations, are locally owned, supply a local market, and each affects less than 12 acres. A similar operation has gone out of business. Grading and seeding at that site were completed early in 1974.

This study, which is a joint effort of the Montana Department of Fish and Game and Consol, was undertaken with the following overall objectives: (1) to determine the impact, or potential impact, of surface mining upon the wildlife resource in this area; (2) to ensure that wildlife habitat values receive fult recognition in any mining or reclamation effort; and (3) to investigate possible modifications or innovations in the reclamation process to avoid unnecessary loss of wildlife habitat.

Two earlier reports (Dusek and McCann 1973 and 1974) included: inventory and baseline data regarding principal game species and nongame mammals that occur in the Bul1 Mountains; a brief discussion of rest-rotation grazing and its possible application on surface owned and leased by Consol; and vegetational data and wildlife activity at Consol's test pit. This report, covering the period of March 1974 through February 1975, includes: additional data on the ecological relationships of wildiffe in the Bull Mountains; data regarding vegetational development on small acreages that have undergone mining and a reclamation process, and use of these areas by wildlife; and a specific grazing management proposal for property owned and leased by Consol.

\section{STUDY AREA}

\section{Location}

The Bull Mountains include that portion of Musselshell County which lies south of the Musselshell River as well as a portion of northern Yellowstone County (Figure T). Lives tock production has been the principal industry since early settlement. Other major land uses include timber production and homesite development. Some of the more gentle terrain is under cultivation. The physiography of the area has been discussed in previous reports (Dusek and McCann 1973 and 1974). 
LEGEHD:

PERHANENT STREAM

INTERMITTENT STREAMS

PAVED ROADS

UNPAVED ROADS

OUTCROP OF MAMMOTHFREHDER COAL SEAM — ?

ELEVATION (feet above sea level)

SUARE DEAL COAL MINE

B0VIRUP

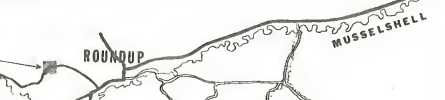

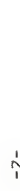

is

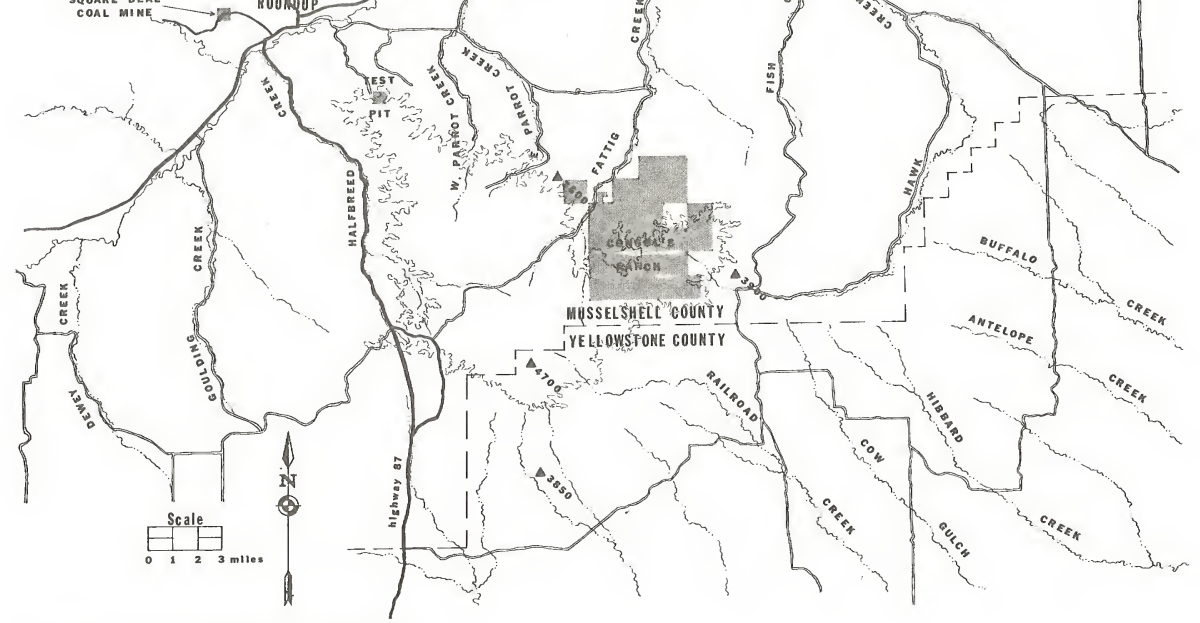

Figure 1. Bull Mountains study area. 


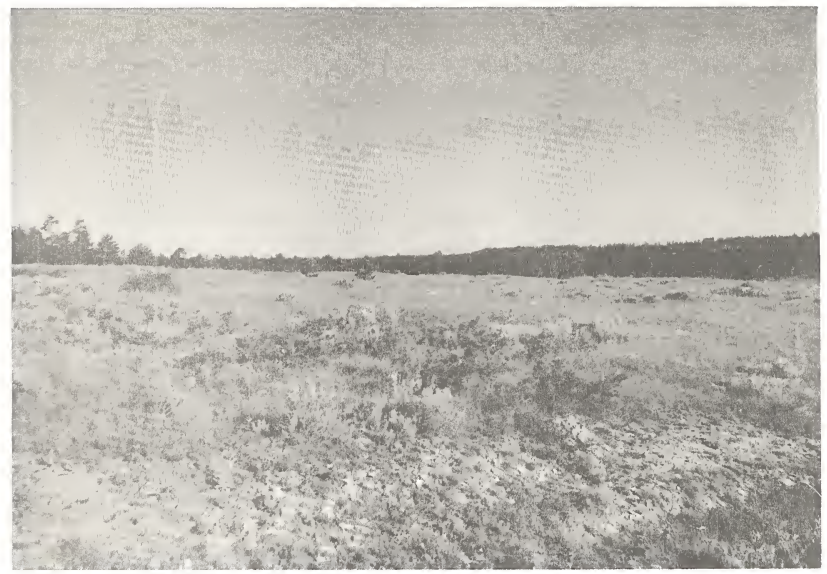

Climate

Climatological data were taken from that recorded at Roundup (U.S. Dept. of Comm. 1972-75), located on the northern edge of the study area. Monthly data appear in Table 1. The warmest average monthly temperature normally occurs during July and the coldest during January. Annual precipitation averages nearly 11 inches, of which approximately half is normally received during May, June and July.

The May-June period during 1974 was characterized by below nomal precipitation, while that received during the months of April and August was above normal. This was comparable to the trend exhibited during the same period for the two previous years (Table 1). The winter of 1974-75 was generally characterized by above normal precipitation and snow cover appeared to persist over longer periods than during the two previous winters. Temperatures during January 1975 were slightly above normal, while those during February averaged 11.8 degrees below normal. 
Table 1. Climatological data for Roundup, Montana, covering the period January 1972-February 1975.

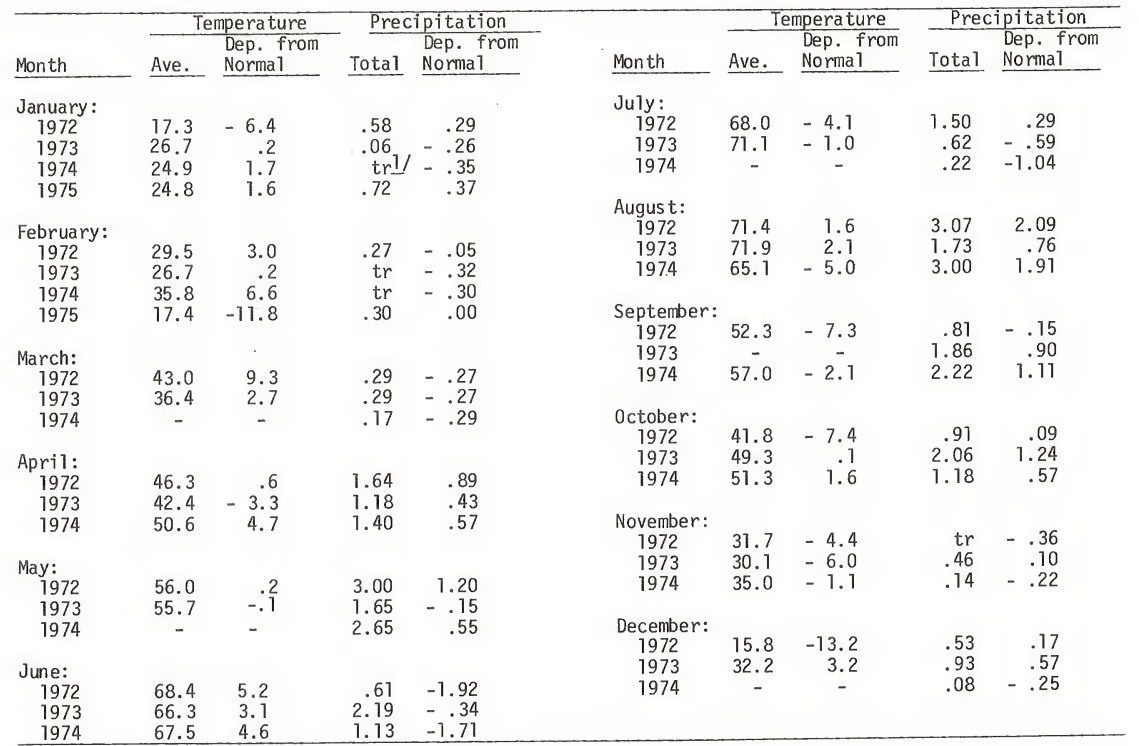

1/ $\mathrm{tr}$ - Trace (an amount too small to measure) 
$\underline{\text { Vegetation }}$

Six vegetation types were identified on the study area. These included the grassland, agricultural, sagebrush-grassland, deciduous shrub, ponderosa pine-grassland, and ponderosa pine. All types, except the ponderosa pine type, were separated into two or three subtypes. A quantitative or qualitative description of each type and subtype appeared in a previous report (Dusek and McCann 1974).

\section{PHASES OF STUDY}

The project was divided into four separate parts which include: a general wildlife ecology study, a rest-rotation grazing study, revegetation studies, and, an inventory of nongame mammals. Each phase will be discussed in this report.

\section{General Wildlife Ecology Study}

The purpose of this phase was to determine specific habitat requirements of principal game species, identify potential conflicts between game animals and coal development, and determine what reclamation procedures will best fulfill habitat requirements of game animals.

Mule deer (Odocoizeus hemionus), elk (Cervis canadensis), Merriam's turkey (Meleagris gallopavo merriami), and pronghom antelope (Antizocapra americana) were the game species most often observed and are the only ones that will be discussed in any detail. White-tailed deer codocoileus virginiana) and sharp-tailed grouse (Pedioecetes phasianellus) also occur in the Bull Mountains, but it is felt the small number of observations of those two species would not provide meaningful data.

Observations of animals were facilitated by surveys from fixed-wing aircraft, by vehicle, or on foot. Animals were classified as to sex and whether adult or juvenile. Vegetation type and subtype, class of slope, gradient and exposure occupied by the various species were noted. The estimated distance from observed animals to the nearest stand of timber was recorded also. Observations of individually marked mule deer and elk were located to the nearest quarter section, or if possible, to the nearest 40 acres. All unmarked animals were located to the nearest section. Food habits of mule deer were estimated by examination of rumen contents and feeding sites.

\section{Mule Deer}

Aerial and ground data have been combined in the following analysis. Data were based on 1,892 observations made during the report period which included 875 and 1,017 deer from ground and aerial surveys, respectively.

Distribution and Range Use

Seasonal distribution of mule deer followed a trend similar to that observed during previous years (Dusek and McCann 1973 and 1974). Distribution of deer did not appear to change appreciably throughout the year, suggesting that they were nonmigratory (Figure 2). 


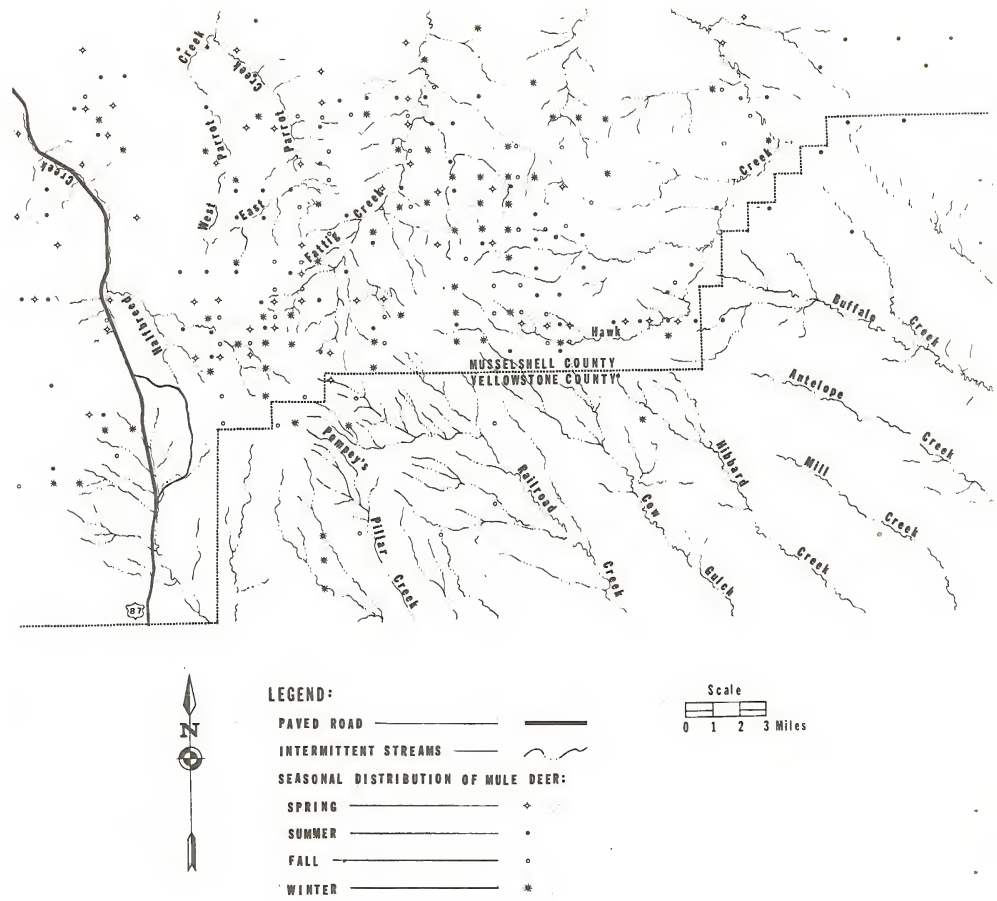

Figure 2. Seasonal distribution of mule deer in the Bull Mountains during the report period ending February 28, 1975. Each data point represents the occurrence of deer in an area during a respective season. 


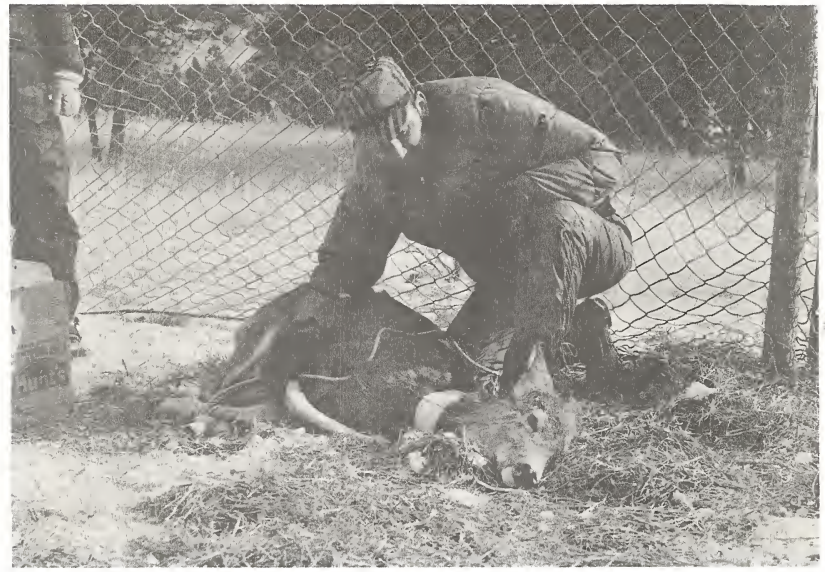

Movements

Twenty-one mule deer were captured and individually marked during the period of March 1974 through February 1975. Ten were captured on Consol's property in the Fattig Creek drainage. Three Oregon-style deer traps were used in that area. Eleven deer were captured in the upper Halfbreed Creek drainage with a corral-type trap (Stoneberg 1973). Each animal was fitted with an individually color-coded neckband which consisted of "Saflag" sewn onto a canvas web backing. Capture and relocation data for individual animals marked since January 1973 appear in Table 2, except for one animal captured in February 1974 from which a neckband was returned.

Seasonal movements for two adult females, ear tag numbers D-1604 and D-1629, captured at the same trap site during January 1973, were estimated by six and seven observations, respectively (Figure 3 ). Most relocations of these animals were made during spring 1974 and D-1629 was not observed during either summer. All relocations were within 1.25 miles of the trap site. During summer, fall, winter or late spring, the two does were observed in nonagricultural types in side drainages of Fattig Creek (Figure 3 ). During the period of March 25 through April 18, 1974, both were observed on a cultivated area on Fattig Creek. All five deer marked in the Fattig 
Table 2. Capture and relocation data on 27 mule deer captured and individually marked from January 1973 through February 1975.

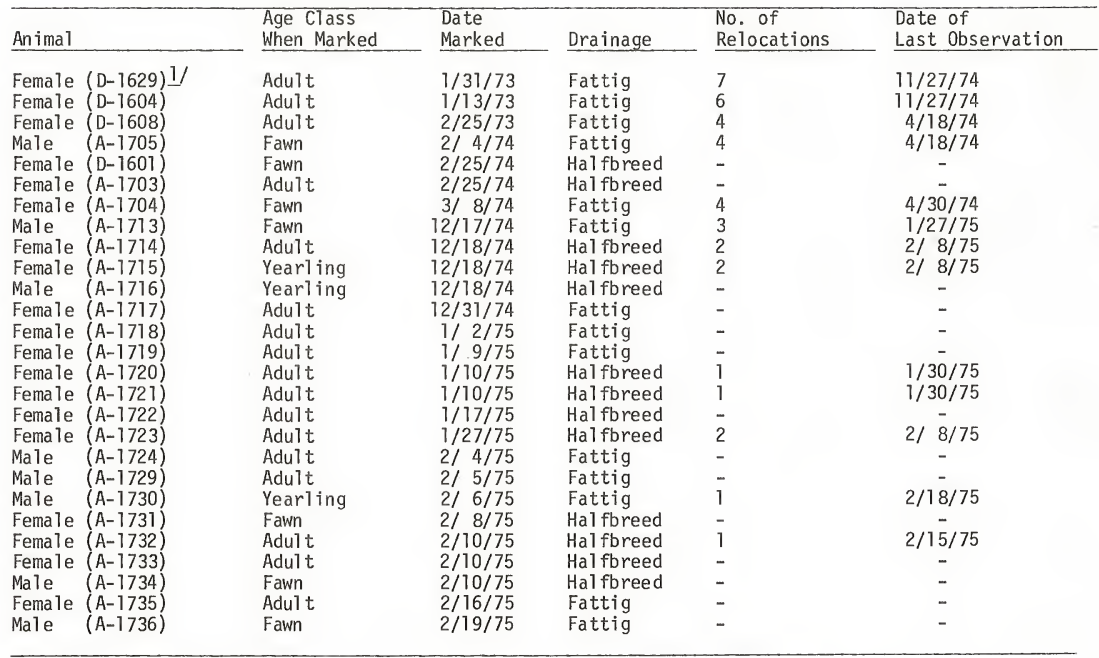

1/ Number on metal ear tag 

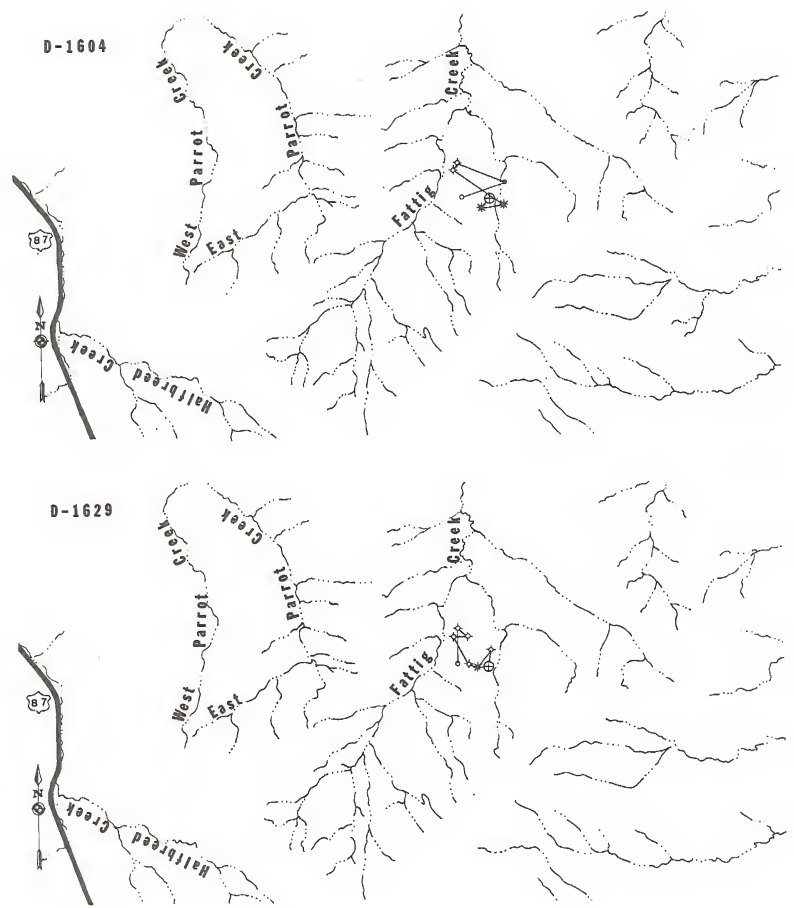

LEGEND:

PAVED ROAD
INTERMITTENT STREAMS

RELOCATIONS OF ADULT FEMALE MULE DEER:

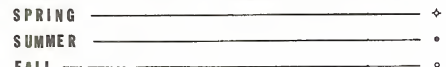

FALL - - O

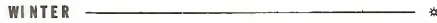

CAPTURE SITE - $\oplus \begin{array}{lllll}0 & 1 & 2 & 3 & \text { Miles }\end{array}$

Figure 3. Seasonal distribution and movements of two adult female mule deer captured during January 1973 in the Fattig Creek drainage. 
Creek drainage up to that time, which also included D-1608, A-1704, and A-1705 (Table 2), were each observed at least twice in this cultivated area.

Home ranges (Dice 1952) were estimated by connecting the outside points (Figure 3 ) and calculating the size of the area within. The respective home ranges for the two adult females (D-1604 and D-1629) were 720 and 380 acres. Due to the small number of relocations of the two animals, their home ranges were perhaps underestimated. Even with that in mind, they were larger than those reported for adult females in the Missouri River Breaks (Mackie 1970).

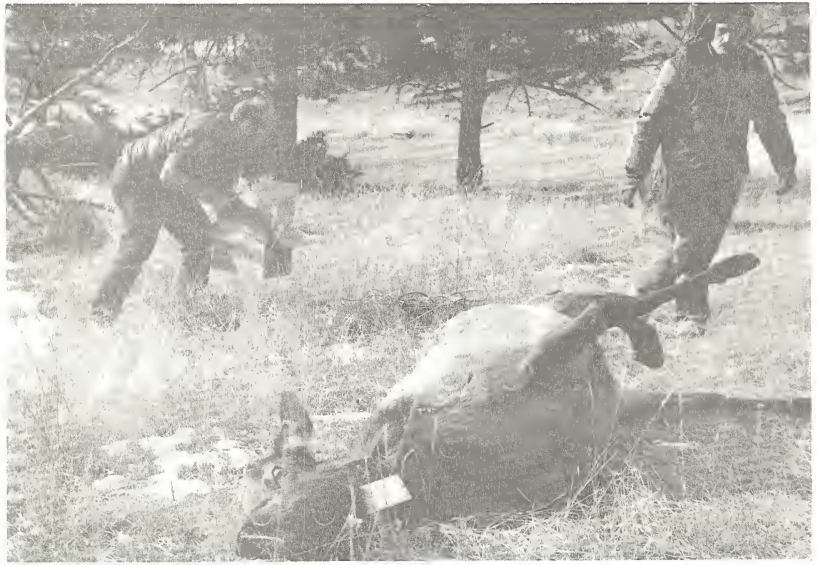

Group Characteristics

Group sizes during the report period were smallest during summer 1974 with a mean of 2.2 animals per group. Summer groups of five or more deer were almost invariably buck groups or buck/doe groups not accompanied by fawns. Average group sizes increased during the following fall and winter with means of 4.4 and 4.6 , respectively.

The largest average group size of 5.6 deer was recorded during the spring of 1974. This was perhaps related to increased use of open vegetation 
types, such as the grassland and agricultural types, and/or concentration on certain sites as suggested by Mackie (1970). As mentioned previously, all five animals that were individually marked within a quarter section area in the Fattig Creek drainage during the winters of 1973 and 1974 were al1 observed in a cultivated area on Fattig Creek during spring 1974. On two occasions, four of these deer were observed within a single group, and on one occasion, all five were observed within a single group on that site. This perhaps reflected the overlap of home ranges of the individual animals involved.

\section{Use of Vegetation Types}

Observations of mule deer were facilitated by periods of activity such as feeding. Following these periods, or when alarmed, deer used stands of timber for escape cover. Since only the vegetation type and subtype the animals occupied when first observed were recorded, the actual importance of timber to mule deer was perhaps underestimated. The relative use of vegetation types by deer throughout the report period (Table 3 ) generally followed a pattern similar to that observed during previous years unless otherwise specified (Dusek and McCann 1973 and 1974).

Spring: During spring 1973 the grassland and agricultural types, combined, received the greatest use, accounting for 70 percent of the seasonal observations. The drainageway and cropland subtypes accounted for the greatest use within their respective types (Table 3 ). The agricultural type appeared to receive its greatest seasonal use between March 20 and Apri1 20, 1974. This was perhaps related to an earlier development of vegetative growth on this type than on nonagricultural types. As vegetative growth developed on the nonagricultural types, a shift by deer to those types occurred.

Summer: Data gathered during summer 1974 reflected an increase in use of the grassland type by deer and a decrease in use of the agricultural type al though the two types combined accounted for 69 percent of the seasonal observations (Table 3 ). The grassland park and drainageway subtypes in the grassland type received considerable use while hay meadows received the greatest use in the agricultural type. The ponderosa pine-grassland type was the only other that received any appreciable use during this season.

Fal1: An increase in use of the grassland type was observed during fall $\overline{1974}$ as compared to summer observations, while use of the agricultural type remained about the same. The two types combined accounted for 75 percent of the seasonal observations. Use of the grassland park subtype was more than twice that observed during summer (Table 3 ). Use of the agricultural type was distributed almost evenly between cropland and hay meadows. The ponderosa pine-grassland type received its lowest yearlong use.

Winter: The winter of 1974-75 was characterized by harsher climatic conditions than were experienced during the two previous winters, especially during February (Table 1). Eighty-three percent of the seasonal observations were evenly distributed between the ponderosa pine-grassland, sagebrush-grassland and grassland types (Table 3 ). The ponderosa pine-bunchgrass, silver sagebrush-grassland and grassland park subtypes accounted for the bulk of the observations in the respective types. The agricultural type 
Table 3. Seasonal use of vegetation types and subtypes by mule deer as determined by 1892 ground and aerial observations during the report period.

\begin{tabular}{|c|c|c|c|c|}
\hline \multirow[b]{2}{*}{ Vegetation Type } & \multicolumn{4}{|c|}{ Season } \\
\hline & $\begin{array}{l}\text { Spring } 7974 \\
(580) 1 /\end{array}$ & $\begin{array}{l}\text { Summer } 1974 \\
(355)\end{array}$ & $\begin{array}{l}\text { Fal } 1974 \\
(483) \\
\end{array}$ & $\begin{array}{l}\text { Winter } 7974-75 \\
(474)\end{array}$ \\
\hline \multicolumn{5}{|l|}{ Grass land Type: } \\
\hline Grass land Park Subtype & 1021 & 12 & 26 & 21 \\
\hline Drainageway Subtype & 17 & 16 & 14 & 3 \\
\hline Burn Subtype & 3 & 8 & 1 & 3 \\
\hline TOTAL & 30 & 36 & 47 & 27 \\
\hline \multicolumn{5}{|l|}{ Agricultural Type: } \\
\hline Cropland & 29 & 5 & 18 & 8 \\
\hline Hay Meadow & 11 & 28 & 16 & 2 \\
\hline TOTAL & 40 & 33 & 34 & 10 \\
\hline \multicolumn{5}{|l|}{ Sagebrush-Grassland Type: } \\
\hline Silver Sagebrush-Grassland Subtype & 8 & 5 & 10 & 26 \\
\hline Big Sagebrush-Grassland Subtype & - & - & $\operatorname{tr}$ & 2 \\
\hline TOTAL & 8 & 5 & 10 & 28 \\
\hline \multicolumn{5}{|l|}{ Deciduous Shrub Type: } \\
\hline Skunkbush Subtype & - & 4 & 4 & 2 \\
\hline Snowberry Subtype & 1 & 3 & 1 & 2 \\
\hline TOTAL & $T$ & 7 & 5 & 4 \\
\hline \multicolumn{5}{|l|}{ Ponderosa Pine-Grassland Type: } \\
\hline Ponderosa Pine-Bunchgrass Subtype & 19 & 18 & 10 & 26 \\
\hline Ponderosa Pine-Juniper Subtype & 1 & 1 & - & 2 \\
\hline TOTAL & 20 & 19 & 10 & 28 \\
\hline Ponderosa Pine Type: & 1 & $\operatorname{tr} \underline{3}$ & - & 3 \\
\hline \multicolumn{5}{|l|}{$\begin{array}{l}\frac{1 /}{2 /} \text { Sample size for a respective season } \\
\frac{2}{3 /} \text { Percent of seasonal observations } \\
\text { Trace - a value less than } 1 \text { percent }\end{array}$} \\
\hline
\end{tabular}


received its lowest yearlong use during this season while the sagebrushgrassland type received its highest. The pattern observed during this winter is in contrast to that observed during the previous two winters (Dusek and McCann 1973 and 1974) which might suggest that the relative use by deer would tend to be concentrated on fewer types under harsh climatic conditions than would be the case under milder conditions.

\section{Relation to Timber}

During the report period the distance from each observed group of mule deer to the nearest stand of timber was estimated. Data in Table 4 reflect the percentage of the total number of deer observed during a given season rather than the total number of groups.

A greater percentage of observations occurred within 0-100 feet of the nearest stand of timber than occurred in any of the other three distance classes during a 11 seasons (Table 4). The percentage occurring in that distance class increased progressively from spring 1974 to winter 1974-75, while observations in the 100-300 and 300-600 feet classes, combined, decreased. Deer were rarely observed at distances greater than 600 feet from the nearest stand of timber, especially during winter. This yearlong pattern appeared to be partly related to the pattern of use of vegetation subtypes. For example, as occurrence of mule deer on large open subtypes associated with major drainages decreased, use of smal1 openings in the timber canopy, such as grassiand parks, increased. Many of the large open parks are characterized by an irregular pattern. Mule deer always used timber for escape although they didn't always use the nearest stand of timber.

\section{Use of Slopes}

Seasonal use of six identified classes of topographical features appears in Table 5 . Coulee and creek bottoms, ridges and plateaus were considered flatlands while sidehills and coulee heads, combined, were separated into three classes based on the degree of slope (Table 6).

Collectively, flatlands received more than 50 percent of the use during all seasons with the highest use occurring during spring and fall (Table 6). This was influenced largely by observations occurring on creek bottoms and plateaus during spring and fall, respectively (Table 5). The greatest seasonal use of gentle and medium slopes, combined, occurred during winter. Deer were rarely observed on steep slopes during the report period, although the greatest use occurred on that class of gradient during spring. With the exception of the fall period, these data are in contrast to that reported by Martin (1975) for the Sarpy Creek area. Data regarding relative use by mule deer of topographical features in the Bu17 Mountains during this report period together with that of previous years (Dusek and McCann 1973 and 1974) did not indicate a distinct yearlong trend. This leads the writer to believe that, in an area characterized by a diverse topographical pattern, preferences for and availability of forage together with climatic conditions influence the use of an area by deer more than do preferences for topographical features or gradients. 
Table 4. Occurrence of mule deer at various distances from the nearest stand of timber, determined from 1,892 ground and aerial observations.

\begin{tabular}{|c|c|c|c|c|}
\hline Distance Class & $\begin{array}{l}\text { Spring } 1974 \\
(557) !\end{array}$ & $\begin{array}{l}\text { Summer } 1974 \\
(355)\end{array}$ & $\begin{array}{l}\text { Fal1 } 1974 \\
(486)\end{array}$ & $\begin{array}{l}\text { Winter 1974-75 } \\
(474) \\
\end{array}$ \\
\hline $\begin{array}{l}0-100 \mathrm{ft} . \\
100-300 \mathrm{ft} . \\
300-600 \mathrm{ft} . \\
\text { Over } 600 \mathrm{ft} .\end{array}$ & $\begin{array}{l}3621 \\
34 \\
21 \\
8\end{array}$ & $\begin{array}{l}39 \\
34 \\
14 \\
13\end{array}$ & $\begin{array}{l}45 \\
23 \\
21 \\
11\end{array}$ & $\begin{array}{r}61 \\
22 \\
16 \\
1\end{array}$ \\
\hline
\end{tabular}

1/ Sample size for a respective season

2) Percent of seasonal observations

Table 5. Seasonal use of various topographical features by mule deer as determined from 1,892 ground and aerial observations during the report period.

\begin{tabular}{|c|c|c|c|c|c|c|}
\hline \multirow[b]{2}{*}{ Season } & \multicolumn{6}{|c|}{ Class of slope } \\
\hline & Sidehil1 & $\begin{array}{l}\text { Coulee } \\
\text { Bottom }\end{array}$ & $\begin{array}{l}\text { Creek } \\
\text { Bottom }\end{array}$ & Ridge & Plateau & $\begin{array}{r}\text { Coulee } \\
\text { Head }\end{array}$ \\
\hline $\begin{array}{l}\text { Spring } 1974(580) \text { l/ } \\
\text { Summer } 1974(355) \\
\text { Fal1 1974 (483) } \\
\text { Winter 1974-75 (474) }\end{array}$ & $\begin{array}{l}2921 \\
35 \\
28 \\
40\end{array}$ & $\begin{array}{r}18 \\
14 \\
9 \\
7\end{array}$ & $\begin{array}{r}18 \\
13 \\
12 \\
7\end{array}$ & $\begin{array}{r}6 \\
6 \\
10 \\
10\end{array}$ & $\begin{array}{l}24 \\
22 \\
37 \\
27\end{array}$ & $\begin{array}{l}5 \\
9 \\
5 \\
9\end{array}$ \\
\hline
\end{tabular}

1/ Sample size for a respective season

2/ Percentage of seasonal observations

Table 6. Seasonal use of gradients by mule deer during the report period.

\begin{tabular}{|c|c|c|c|c|}
\hline Gradient & $\begin{array}{l}\text { Spring } 1974 \\
(580) 1 /\end{array}$ & $\begin{array}{c}\text { Summer } 1974 \\
(355)\end{array}$ & $\begin{array}{l}\text { Fall } 1974 \\
(483) \\
\end{array}$ & $\begin{array}{l}\text { Winter 1974-7 } \\
(474) \\
\end{array}$ \\
\hline $\begin{array}{l}\text { Flat2/ } \\
\text { Gentle }\left(0-15^{0}\right) \\
\text { Medium }(16-300) \\
\text { Steep }(31-450)\end{array}$ & $\begin{array}{l}66 \underline{3} / \\
12 \\
16 \\
5\end{array}$ & $\begin{array}{r}57 \\
27 \\
15 \\
1\end{array}$ & $\begin{array}{r}68 \\
26 \\
5 \\
1\end{array}$ & $\begin{array}{r}53 \\
35 \\
10 \\
1\end{array}$ \\
\hline
\end{tabular}

1/ Seasonal sample size

$\frac{1}{2}$ Includes coulee bottoms, creek bottoms, ridges and plateaus

3/ Percent of seasonal sample 
Use of Exposures

During winter 1974-75, 58 percent of the observations of mule deer associated with some degree of slope occurred on southerly exposures (Table 7). Slopes having an east exposure received considerable use during this season also. Use of west exposures was greatest during spring and summer while greatest use on northerly exposures occurred during summer and fall. These findings are comparable with those of previous years (Dusek and McCann 1973 and 1974) and those reported by Martin (1975). There did not appear to be any difference between mild and harsh winters regarding occurrence of mule deer on southerly exposures.

Table 7. Seasonal use of eight exposures by mule deer as determined from 692 ground and aerial observations during the report period.

\begin{tabular}{|c|c|c|c|c|c|c|c|c|}
\hline Season & North & East & South & West & NE & NW & SE & SW \\
\hline $\begin{array}{l}\text { Spring } 1974 \\
(188) ! /\end{array}$ & 621 & וו & 17 & 14 & 5 & 7 & 28 & 12 \\
\hline $\begin{array}{l}\text { Summer } \\
(143)\end{array}$ & 21 & 17 & 9 & 17 & 6 & 19 & 16 & 5 \\
\hline $\begin{array}{l}\text { Fal } 11974 \\
(153)\end{array}$ & 17 & 11 & 19 & 12 & 12 & 4 & 20 & 5 \\
\hline $\begin{array}{l}\text { Winter } 1974-75 \\
(208)\end{array}$ & 12 & 22 & 43 & 2 & 5 & 1 & 7 & 8 \\
\hline
\end{tabular}

1/ Sample size occurring on some degree of slope during a respective season $\underline{2}$ ) Percent of seasonal observations associated with some degree of slope

Food Habits

Food habits during fall 1974 were estimated by examination of rumen samples from nine hunter-killed deer. Those during winter 1974-75 were estimated from examination of 8 feeding sites which included 1,189 instances of use. Results from both seasons appear in Table 8. Four browse utilization transects aided in determining relative use and periods of use of browse species (Table 9 ).

\section{Fall}

During fall 1974, forbs, browse and grasses constituted 51,33 and 7 percent, by volume of the nine rumens. Mushrooms accounted for an additional 10 percent. Aster (Aster spp.) and alfalfa (Medicago sativa) accounted for 20 and 16 percent of the seasonal diet, respectively, and were the most abundant forbs. Snowberry (Symphoricarpos spp.), which constituted 26 percent, was the most abundant shrub as well as the most abundant 
Table 8. Fall and winter food habits of mule deer as determined from examination of rumen samples and feeding sites.

\begin{tabular}{|c|c|c|}
\hline Taxa & $\begin{array}{r}\text { Fal } 1974 \\
9 \text { Rumens }\end{array}$ & $\begin{array}{c}\text { Winter 1974-75 } \\
8 \text { sites } \\
(1189) 1 / \\
\end{array}$ \\
\hline $\begin{array}{l}\text { Browse: } \\
\text { Artemisia cana } \\
\text { Chrysothamus nauseosus } \\
\text { Juniperus communis } \\
\text { Juniperus horizontalis } \\
\text { Juniperus scopulomm } \\
\text { Juniperus spp. } \\
\text { Pinus ponderosa } \\
\text { Rhus trilobata } \\
\text { Rosa spp. } \\
\text { Symphoricarpos spp. } \\
\text { Unidentified Browse }\end{array}$ & $\begin{array}{l}11 / 22 / \\
- \\
- \\
- \\
- \\
11 / \operatorname{tr} 3 / \\
44 / 7 \\
44 / 1 \\
56 / 2 \\
78 / 26 \\
11 / 1\end{array}$ & $\begin{array}{l}100 / 78 \\
12 / 7 \\
12 / 2 \\
12 / \mathrm{tr} \\
12 / 1 \\
- \\
12 / \mathrm{tr} \\
37 / 5 \\
- \\
12 / \mathrm{tr} \\
-\end{array}$ \\
\hline TOTAL Browse & $700 / 33$ & $100 / 93$ \\
\hline $\begin{array}{l}\text { Forbs: } \\
\text { Achizlea mizlefolium } \\
\text { Artemisia Zudoviciana } \\
\text { Aster spp. } \\
\text { COMPOSITAE } \\
\text { LEGUMINOSAE } \\
\text { Medicago sativa } \\
\text { Melizotus officinalis } \\
\text { Tragopogon dubius } \\
\text { Yucca glauca } \\
\text { Unidentified Forbs }\end{array}$ & $\begin{array}{l}-\bar{x} \\
33 / 1 \\
89 / 20 \\
11 / \operatorname{tr} \\
22 / \mathrm{tr} \\
44 / 16 \\
11 / \mathrm{tr} \\
- \\
22 / 1 \\
89 / 13\end{array}$ & $\begin{array}{c}12 / \mathrm{tr} \\
- \\
12 / \mathrm{tr} \\
- \\
- \\
- \\
- \\
25 / \mathrm{tr} \\
25 / 5 \\
-\end{array}$ \\
\hline TOTAL Forbs & $700 / 57$ & $75 / 5$ \\
\hline Grasses: & $67 / 7$ & $37 / \mathrm{tr}$ \\
\hline Mushrooms: & $89 / 10$ & - \\
\hline
\end{tabular}

1/ The number of instances of use recorded during the winter of 1974-75

2) Frequency (percent occurrence among rumens or feeding sites)/percent of seasonal diet

3) $t r$ - trace (a value less than .5 percent) 
Table 9. Browse utilization data for fall and winter browse species at four locations.

\begin{tabular}{|c|c|c|c|c|c|c|c|c|}
\hline \multicolumn{3}{|c|}{ Location } & \multirow{2}{*}{$\begin{array}{l}\text { Plot } \\
\text { No. }\end{array}$} & \multicolumn{2}{|c|}{ Key Plants } & \multirow{2}{*}{\multicolumn{2}{|c|}{ Month }} & \multirow{2}{*}{$\begin{array}{r}\text { Percent } \\
\text { Leader Use } \\
\end{array}$} \\
\hline Sec. & TN & $\mathrm{RE}$ & & Spp. & No. & & & \\
\hline \multirow[t]{2}{*}{7} & 6 & 28 & 33 & Chna & 25 & $\begin{array}{l}\text { Apri1 } \\
\text { November }\end{array}$ & $\begin{array}{l}1974 \\
1974\end{array}$ & $\begin{array}{l}84 \\
12\end{array}$ \\
\hline & & & & Artr & 25 & Apri1 & 1974 & 3 \\
\hline \multirow[t]{2}{*}{7} & 6 & 28 & 34 & Rhtr & 25 & $\begin{array}{l}\text { April } \\
\text { November }\end{array}$ & $\begin{array}{l}1974 \\
1974\end{array}$ & $\begin{array}{l}8 \\
2\end{array}$ \\
\hline & & & & Arca & 25 & $\begin{array}{l}\text { Apri } 1 \\
\text { November }\end{array}$ & $\begin{array}{l}1974 \\
1974\end{array}$ & $\begin{array}{l}38 \\
\operatorname{tr}\end{array}$ \\
\hline \multirow[t]{2}{*}{5} & 6 & 28 & 57 & Rhtr & 25 & April & 1974 & 5 \\
\hline & & & & Arca & 25 & April & 1974 & 34 \\
\hline \multirow[t]{2}{*}{8} & 6 & 27 & 488 & Rhtr & 25 & $\begin{array}{l}\text { Apri1 } \\
\text { November }\end{array}$ & $\begin{array}{l}1974 \\
1974\end{array}$ & $\begin{array}{r}17 \\
1\end{array}$ \\
\hline & & & & Arca & 25 & $\begin{array}{l}\text { Apri } 1 \\
\text { November }\end{array}$ & $\begin{array}{l}1974 \\
1974\end{array}$ & $\begin{array}{r}53 \\
0\end{array}$ \\
\hline
\end{tabular}


single species in the diet during fall 1974. Other plant species that occurred in the diet during this season are listed in Table 8.

\section{Winter}

Browse constituted 93 percent of 1,189 instances of use on eight feeding sites during winter 1974-75. Silver sagebrush (Artemisia cana) was the most important shrub, accounting for 78 percent of the seasonal diet. Other shrubs in the winter diet included rubber rabbitbrush (Chrysotharmus nauseosus), skunkbush sumac (Rhus trilobata), and common juniper (Juniperus cormunis). Forbs accounted for 5 percent of the seasonal diet with soapweed (Yucea glauca) the most abundant. Use of grasses during this season was negligible. Data for winter 1974-75, compared closely with that of previous winters (Dusek and McCann 1973-74).

Four browse utilization transects (Cole 1959) were read during April 1974 to estimate utilization during the previous winter. Three were again read during late November to determine pre-winter utilization.

On three transects, utilization of silver sagebrush averaged 42 percent when read during April 1974. When two of these transects were read during late November, the average leader use was less than .5 percent. Annual leader use during the two respective periods for skunkbush was 10 and 1 percent. Where it occurred, rubber rabbitbrush was utilized during both fall and winter, but the heaviest use normally occurs during winter (Table 9).

\section{Population Characteristics}

During spring 1974, a fawn:adult ratio of 29:100 was calculated. This compared closely with data collected during the previous fall and winter (Dusek and McCann 1974). A fawn: doe ratio was not calculated during spring since the sex of adults was not readily determined.

Fawn: doe and fawn:adult ratios were not calculated for summer observations since fawns were not readily observable until August. During fall 1974, fawn:doe and fawn:adult ratios, based on 482 combined ground and aerial observations, were $36: 100$ and $29: 100$, respectively (Table 10). Martin (1975) reported fawn:doe and fawn:adult ratios of $85.7: 100$ and 62.1:100, respectively, during the same period in the Sarpy creek area.

Observations during winter 1974-75 indicated a slight decrease in the number of fawns per 100 does and 100 adults. The respective ratios during winter, based on 474 observations, were 29:100 and 23:100. 
Table 10. Population characteristics of mule deer as determined from 1,891 ground and aerial observations from March 1974 - February 1975.

\begin{tabular}{|c|c|c|c|c|c|c|c|c|c|c|}
\hline \multirow[b]{2}{*}{ Season } & \multicolumn{4}{|c|}{ Adults } & \multirow[b]{2}{*}{ Fawns } & \multicolumn{2}{|c|}{$\begin{array}{l}\text { Uncl. } \\
\text { Sex \& }\end{array}$} & \multirow{2}{*}{$\begin{array}{l}\text { Fawns: } \\
100 \text { Does }\end{array}$} & \multirow{2}{*}{$\begin{array}{l}\text { Fawns: } \\
100 \text { Adults }\end{array}$} & \multirow{2}{*}{$\begin{array}{l}\text { Bucks: } \\
100 \text { Does }\end{array}$} \\
\hline & Does & Bucks & Uncl. & Total & & Age & Total & & & \\
\hline Spring 1974 & 117 & 41 & 234 & 392 & 113 & 75 & 580 & - & $29: 100$ & - \\
\hline Summer 1974 & 181 & 124 & 6 & 311 & 44 & - & 355 & - & - & $68: 100$ \\
\hline Fall 1974 & 289 & 68 & 1 & 358 & 103 & 21 & 482 & $36: 100$ & $29: 100$ & $23: 100$ \\
\hline Winter 1974-75 & 291 & 67 & - & 358 & 84 & 32 & 474 & $29: 100$ & $23: 100$ & $23: 100$ \\
\hline
\end{tabular}




\section{Elk}

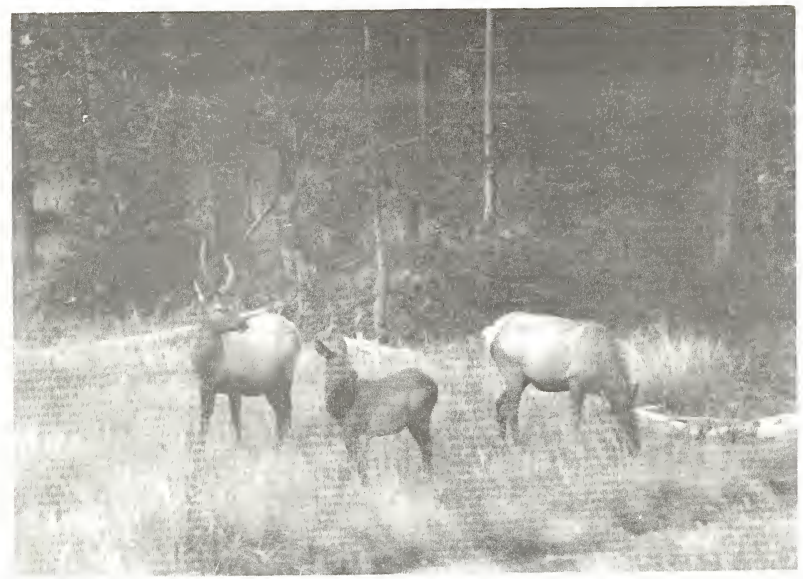

According to available information, elk were first sighted in the Bull Mountains by residents during 1947. Since elk were never transplanted to the area, opinions concerning the origin of the population are varied.

Until 1973, elk had never been legally hunted in the area. Five archery permits were issued during fall 1973 for a portion of hunting district 590 which consisted of deeded and leased surface controlied by Consol. During fall 1974, the same portion of hunting district 590 was open to archers and five rifle permits were also issued during the general season. No elk were reported killed by hunters during either season.

Distribution and Range Use

Data were based on 1,060 observations of elk during the report period. Most were obtained from aerial surveys and supplemented with several observations from the ground.

\section{Distribution and Movements}

Elk in the Bull Mountains appeared to be nonmigratory and the yearlong use of their range paralleled that observed by Mackie (1970) in the 
Missouri River breaks. They differentially used various portions of their range which was separated into two types: that which was used during the winter and spring period and that used during the summer and fall period (Figure 4). This pattern of distribution was similar to that observed during previous years (Dusek and McCann 1974). In two separate areas, groups of adult bulls were observed during both summer and winter. Cows, calves, and yearling, or "spike," bulls were observed in these two areas during summer and fall but not during winter.

Areas where elk were observed throughout the year were concurrently occupied by few, if any, domestic livestock. The upper Hawk Creek drainage, occupied by elk during late spring, summer and fall of 1974 (Figure 4), was characterized by cultivated areas interspersed with timber and grassland containing portions that had been partially logged. Farming activities associated with the cultivated land appeared to cause a temporary shift in the distribution of elk. Cattle were virtually absent from most of this area throughout the summer and early fall of 1974. Within a short period after cattle were turned into some of these areas during October and November, elk were no longer observed on those specific sites.

It would appear that distribution of 1 ivestock does not influence the overall distribution of elk during a given year, but does perhaps influence the distribution of elk within their seasonal range. For example, at least 30 head of elk occurred on Consol's property until late January 1975, where elk had been observed throughout the winter and spring during previous years. The occurrence of livestock appeared unusually high during this winter in areas where elk had been observed during previous winters. During late January and throughout February 1975, most observations of elk occurred south of the Consol property in the Railroad Creek drainage (Figures 1 and 4) where few, if any, livestock occurred. Included in these observations were five adult cow elk that had been individually marked on Consol's property during the winters of 1974 and 1975.

Five adult cows were captured during January 1975 and individually marked with 6-inch-wide neckbands similar to the 3 -inch bands used on mule deer. Capture was facilitated by use of a helicopter and a "Cap-Chur" gun (Palmer Chemical and Equipment Co.). Data concerning locations of capture and relocations for these five cows and two adult cows captured during February 1974 appear in Table 11. Animals (1) and (2), both captured during February 1974, were reobserved 15 and 23 times, respectively, throughout the report period. Seasonal relocations for the two animals combined numbered 4, 6, 13 and 15 during spring, summer, fall and winter, respectively. Relocations for the other five animals were obtained only during January and February 1975 and will not be used to calculate seasonal movements and home ranges in this report. 


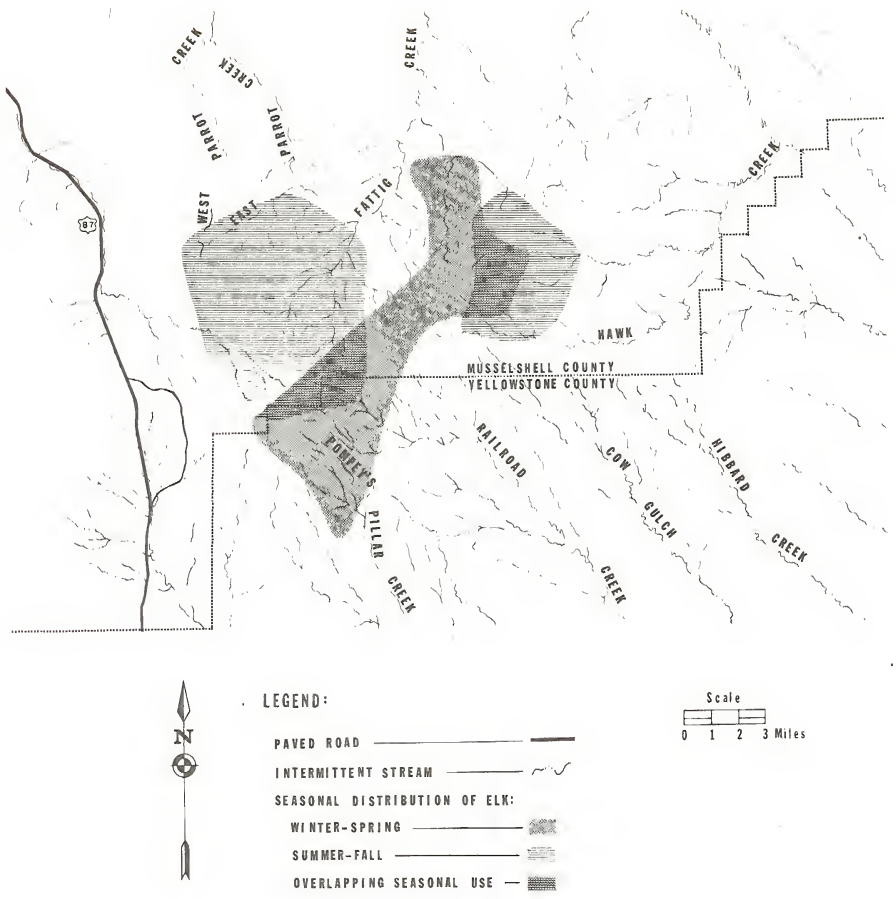

Figure 4. Seasonal distribution of all elk observed in the Bull Mountains during the report period ending February 28, 7975. 


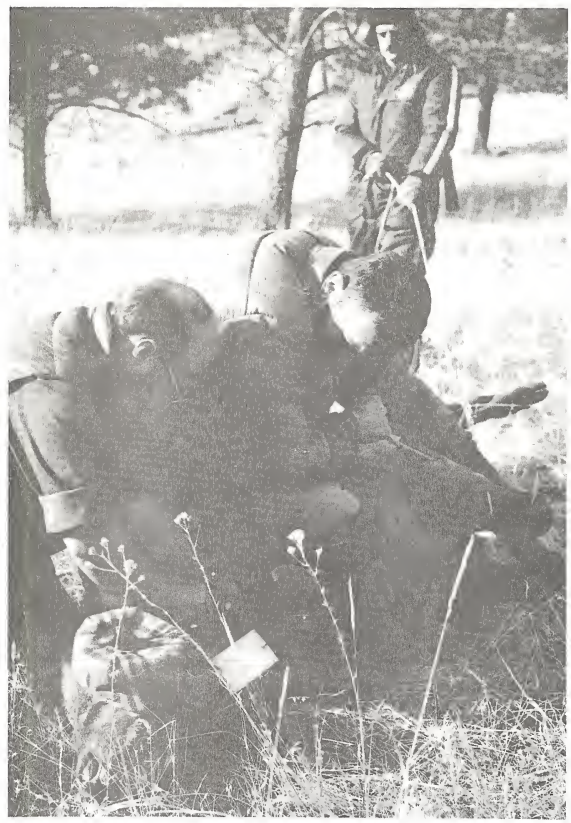

Table 11. Capture and relocation data for seven adult cow elk captured and individually marked during February 1974 and January 1975.

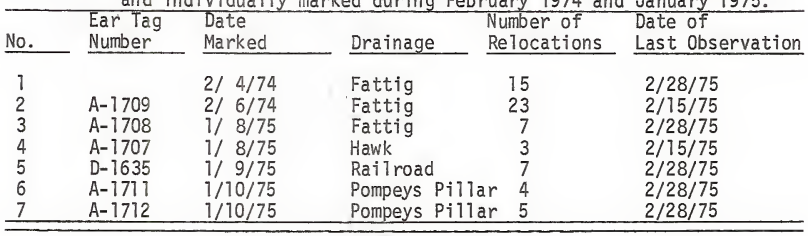


Seasonal movements of elk (1) and (2) are shown in Figures 5 and 6 , respectively. The mean consecutive distances between observations of the two animals combined were $1.5,1.3,2.1$ and 2.7 miles during spring, summer, fall and winter, respectively. Martinka (1969) reported mean consecutive distances of 2.0 and 1.9 miles during early and late summer, respectively, for resident cows in the Jackson Hole area. Mean maximum distances between observations for the same two animals were $2.2,4.2$ and 7.5 miles during summer, fall and winter, respectively. Elk (1) moved 5 miles from morning to evening when observations were made one day during January 1975.

Home ranges for elk (1) and (2) were calculated in the same manner as those for mule deer. Annual home ranges for the two cows were 28.7 and 27.7 square miles, respectively. Both spent the late spring, summer and fall of 1974 in the upper Hawk Creek drainage, and the winter in the Fattig Creek and Railroad Creek drainages (Figures 5 and 6 ). This pattern corresponded closely to the seasonal pattern illustrated in Figure 4 which included all observations of elk during the report period. The respective portions used by the two cows during the summer-fall period included 7.1 and 7.7 square miles, while those used during the winter-spring period were 8.4 and 9.1 square miles, respectively.

It is the writer's opinion that at least two separate and distinct summer ranges occur (Figure 4), and perhaps each was used by separate segments of the population. As indicated through sightings of the seven marked cows during winter 1975, a portion of the total area used by al 1 elk during the winter-spring period may be shared by two or more segments.

\section{Group Characteristics}

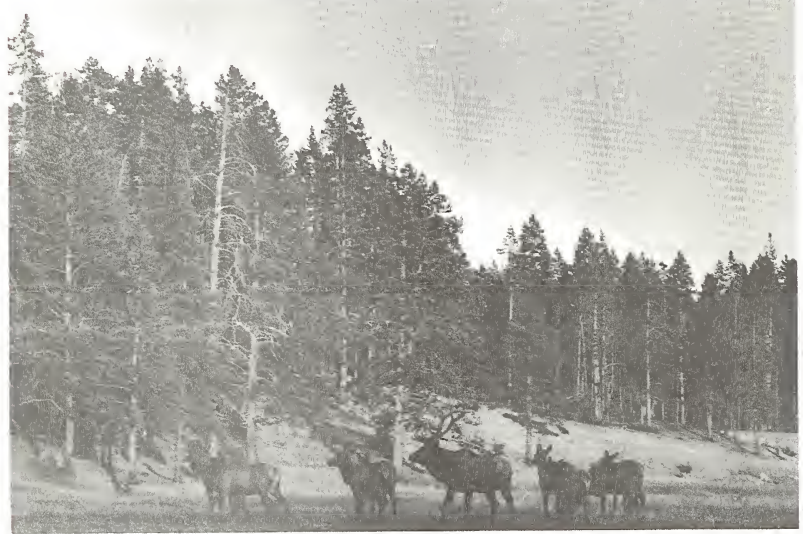




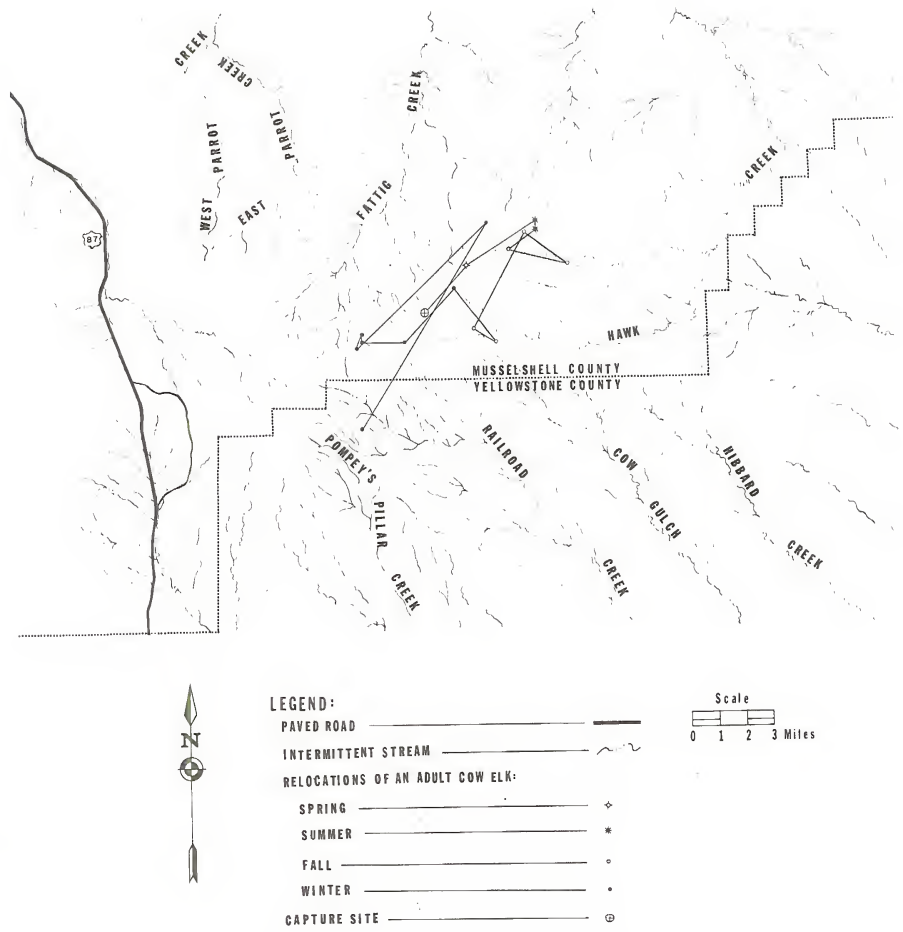

Figure 5. Seasonal distribution and movements of adult cow (1) during the report period ending February 28, 1975. 


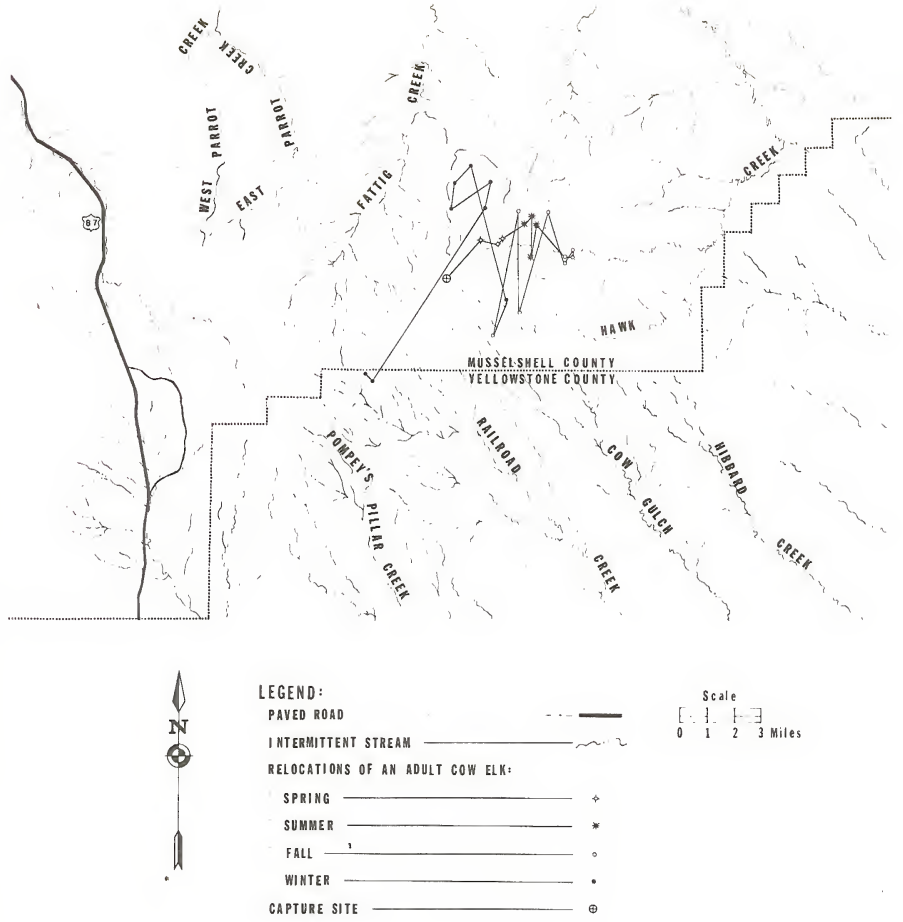

Figure 6. Seasonal distribution and movements of adult cow (2) during the report period ending February 28, 1975. 
Average group sizes were typically largest in number during fall and winter and smallest during spring. Group sizes for the respective seasons during the report period averaged $3.8,6.2,8.9$ and 8.3 for spring, summer, fall and winter. The seasonal averages, as well as group composition, followed a pattern similar to that reported for the previous year (Dusek and McCann 1974). Based on observations of groups of elk containing one or more marked cows, composition of individuals within groups appeared to change quite often. However, some marked cows were observed in a group with certain other marked cows more often than with others. Elk (1) and (2) were observed with the same group on four occasions and were observed in separate groups within a mile of each other on two occasions. The closest association of these two animals occurred during the summer-fall period. They were observed in the same group once during January 1975, but (1) was observed several hours later 5 miles to the south in a group which contained cow (5).

\section{Use of Vegetation Types}

Spring: The grassland type received the greatest use during spring 1974 , followed by the agricultural type (Table 12). The two types combined received 70 percent of the seasonal use, most of which occurred in the grassland park and cropland subtypes. The ponderosa pine-grassland type also received considerable use during spring.

Summer: Sixty-nine percent of the seasonal use was distributed evenly among the grassland and agricultural types during summer 1974. The grassland park subtype accounted for the greatest use in the grassland type, while both cropland and hay meadows received nearly equal use in the agricultural type (Table 12). The agricultural type received considerable use throughout the summer of 1974, as opposed to only late summer use during the previous year (Dusek and McCann 1974). Also, the ponderosa pine-grassland type received its lowest yearlong use during summer 1974 as opposed to its greatest yearlong use during summer 1973.

Fa11: The agricultural type, which accounted for 48 percent of the seasonal observations, received the greatest use during fall 1974. This was followed by the grassland and ponderosa pine-grassland types (Table 12). Cropland, grassland park and ponderosa pine-bunchgrass subtypes received the greatest use within their respective types.

Winter: Fifty-six percent of the seasonal observations occurred in the grassland type during winter 1974-75, most of which occurred in the grassland park subtype (Table 12). The ponderosa pine-grassland and grassland types received their greatest yearlong use during that season, while the agricultural type received its lowest.

\section{Relation to Timber}

Most observations of elk during all seasons throughout the report period occurred within 0-100 feet of the nearest stand of timber (Table 13). This occurrence was greatest during spring 1974 and winter 1974-75, when 71 and 73 percent of the respective observations occurred in that distance class. This also included elk that were actually observed in a stand of 
Table 12. Seasonal use of vegetation types and subtypes by elk as determined from 1060 ground and aerial observations during the report period.

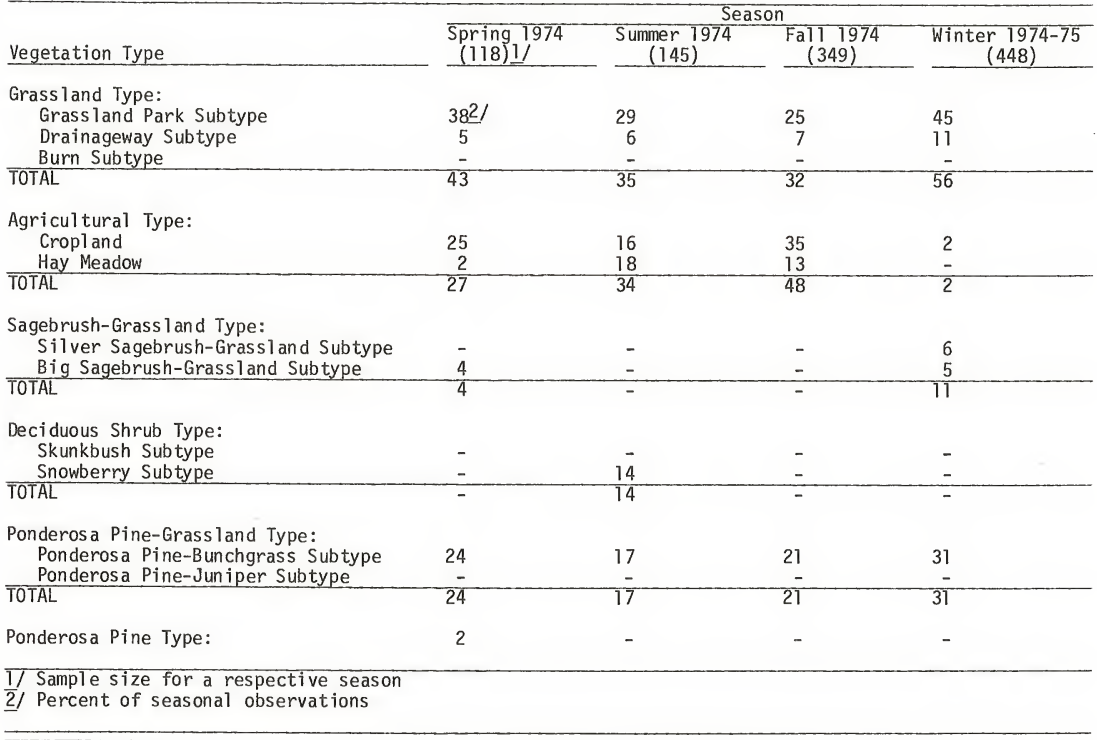


Table 13. Occurrence of elk at various distances from the nearest stand of timber as determined from 1060 ground and aerial observations during the report period.

\begin{tabular}{|c|c|c|c|c|}
\hline Distance Class & $\begin{array}{l}\text { Spring } 1974 \\
(109) 1]\end{array}$ & $\begin{array}{c}\text { Summer } 1974 \\
(145)\end{array}$ & $\begin{array}{l}\text { Fal1 } 1974 \\
(349) \\
\end{array}$ & $\begin{array}{l}\text { Winter 1974-75 } \\
(448)\end{array}$ \\
\hline $\begin{array}{l}0-100 \mathrm{ft} . \\
100-300 \mathrm{ft} . \\
300-600 \mathrm{ft} . \\
\text { Over } 600 \mathrm{ft} \text {. }\end{array}$ & $\begin{array}{l}7121 \\
29 \\
- \\
-\end{array}$ & $\begin{array}{r}47 \\
43 \\
10 \\
-\end{array}$ & $\begin{array}{r}52 \\
33 \\
10 \\
5\end{array}$ & $\begin{array}{r}73 \\
18 \\
9 \\
-\end{array}$ \\
\hline
\end{tabular}

1/ Sample size for a respective season

2) Percent of seasonal observations

Table 14. Seasonal use of various topographic features by elk as determined from 1,060 ground and aerial observations during the report period.

\begin{tabular}{|c|c|c|c|c|c|c|}
\hline \multirow[b]{2}{*}{ Season } & \multicolumn{2}{|c|}{ CouTee } & \multicolumn{2}{|c|}{ Class of Slope } & \multirow[b]{2}{*}{ Plateau } & \multirow[b]{2}{*}{$\begin{array}{l}\text { CouTee } \\
\text { Head }\end{array}$} \\
\hline & Sidehill & $\begin{array}{l}\text { Coutee } \\
\text { Bottom }\end{array}$ & $\begin{array}{l}\text { Creek } \\
\text { Bottom } \\
\end{array}$ & Ridge & & \\
\hline $\begin{array}{l}\text { Spring } 1974(118) \text { ]/ } \\
\text { Summer 1974 (145) } \\
\text { Fal1 1974(349) } \\
\text { Winter 1974-75(448) }\end{array}$ & $\begin{array}{l}27 \underline{21} \\
10 \\
23 \\
29\end{array}$ & $\begin{array}{r}25 \\
22 \\
7 \\
19\end{array}$ & $\begin{array}{r}1 \\
- \\
15 \\
-\end{array}$ & $\begin{array}{r}- \\
3 \\
31\end{array}$ & $\begin{array}{l}26 \\
36 \\
42 \\
14\end{array}$ & $\begin{array}{r}21 \\
28 \\
5 \\
6\end{array}$ \\
\hline
\end{tabular}

1/ Sample size for a respective season

2/ Percentage of seasonal observations 
timber. Only during fall 1974 were elk observed at distances greater than 600 feet from the nearest stand of timber. This yearlong pattern appeared at least partly related to the pattern of use of vegetation subtypes. However, during periods when large openings, dominated by the agricultural type, were used, elk were seldom observed at distances greater than 300 feet from the nearest stand of timber. During winter 1974-75 when the grassland park subtype received its greatest yearlong use (Table 12), nearly three-quarters of the elk observed occurred within 0-100 feet of the nearest stand of timber. In the Little Belt Mountains, Coop (1971) reported an average distance of 224 feet from elk to the nearest timber, but elk ran an average distance of 374 feet to reach escape timber.

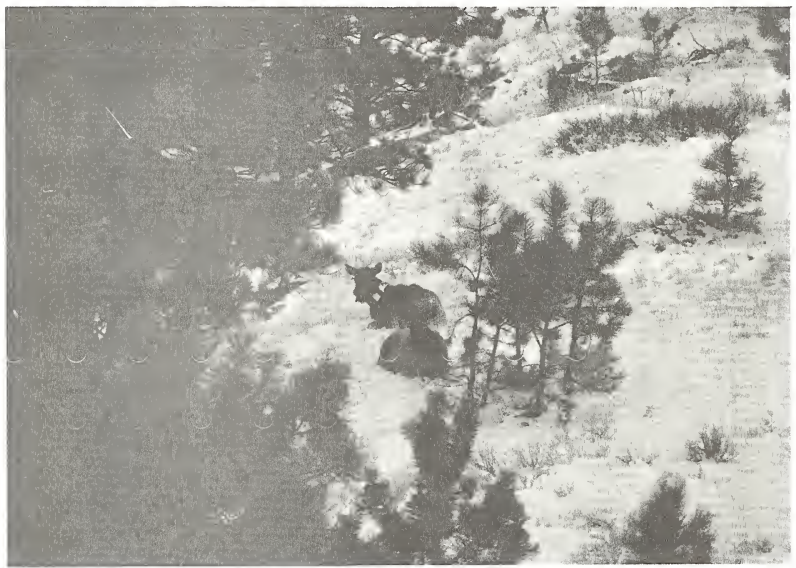

Use of Slopes

Seasonal use by elk of the six classes of topographical features appears in Table 14. More than 50 percent of the elk observed during all seasons occurred on flatlands, although the greatest yearlong use occurred during fall 1974 (Table 15). This was influenced largely by use of plateaus and creek bottoms during fall, which appeared related to use of the agricultural type. Plateaus received heavy use during all seasons except winter, while the only significant use of creek bottoms by elk occurred 
Table 15. Seasonal use of gradients by elk during the report period.

\begin{tabular}{|c|c|c|c|c|}
\hline Gradient & $\begin{array}{l}\text { Spring } 1974 \\
(118) !\end{array}$ & $\begin{array}{c}\text { Summer } 1974 \\
(145)\end{array}$ & $\begin{array}{l}\text { Fal1 } 1974 \\
(349) \\
\end{array}$ & $\begin{array}{l}\text { Winter 1974-75 } \\
\quad(448)\end{array}$ \\
\hline $\begin{array}{l}\text { Flat2/ } \\
\text { Gentle }(0-150) \\
\text { Medium }(16-300) \\
\text { Steep }\left(31-45^{\circ}\right)\end{array}$ & $\begin{array}{l}523 / \\
25 \\
20 \\
3\end{array}$ & $\begin{array}{r}63 \\
36 \\
1 \\
-\end{array}$ & $\begin{array}{l}72 \\
28 \\
\operatorname{tr} \underline{4} \\
-\end{array}$ & $\begin{array}{r}64 \\
23 \\
12 \\
1\end{array}$ \\
\hline
\end{tabular}

1/ Seasonal sample size

2/ Includes coulee bottoms, creek bottoms, ridges and plateaus

3/ Percent of seasonal sample

4/ $\mathrm{tr}$ - trace (a value 1 ess than .5 percent of seasonal sample)

during fall. Coulee bottoms received their heaviest use during spring and summer while ridges received considerable use during winter.

A11 three classes of gradient combined received their greatest use during spring 1974 (Table 15). Gentle slopes received the greatest use of all three classes throughout the report period while the greatest use of medium slopes and the only use recorded on steep slopes occurred during spring and winter. The greatest use of sidehills occurred during spring, fall and winter, while coulee heads received their greatest use during spring and summer (Table 14).

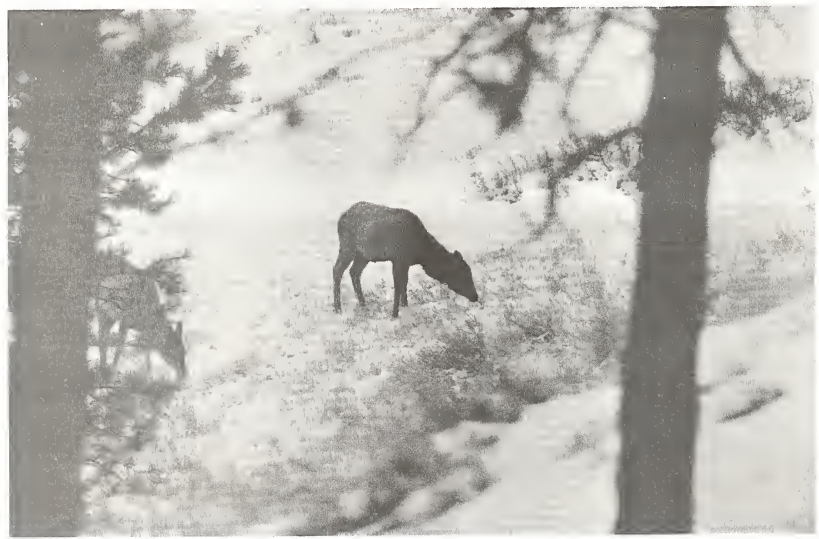


Use of Exposures

During winter 1974-75, 81 percent of the observations of elk associated with some degree of slope occurred on southerly exposures (Table 16). That percentage decreased progressively during spring, summer and fal1. Northerly exposures received their greatest use during summer and fall.

Table 16. Seasonal use of each of eight exposures by elk as determined from 359 ground and aerial observations during the report period.

\begin{tabular}{|c|c|c|c|c|c|c|c|c|}
\hline Season & North & East & South & West & NE & $\underline{N W}$ & $\underline{S E}$ & SW \\
\hline $\begin{array}{l}\text { Spring, } 1974 \\
(47) \underline{I} /\end{array}$ & 19 기 & 11 & 34 & 6 & - & 2 & 28 & - \\
\hline $\begin{array}{l}\text { Summer } \\
(50)\end{array}$ & 10 & - & 18 & - & 24 & 8 & 40 & - \\
\hline $\begin{array}{l}\text { Fal1 } 1974 \\
(98)\end{array}$ & 36 & 29 & 28 & - & - & - & 3 & 5 \\
\hline $\begin{array}{l}\text { Winter } 1974-75 \\
(164)\end{array}$ & 2 & 1 & 37 & 7 & - & 9 & 26 & 18 \\
\hline
\end{tabular}

1/ Sample size for a respective season

2/ Percent of seasonal observations associated with some degree of slope

Population Characteristics

Sex and age ratios were calculated during summer and fall 1974. Ratios were not calculated during the following winter and spring due to difficulty of distinguishing calves from cows. Data appear in Table 17.

Calf:cow and calf:adult ratios for summer 1974 were 54:100 and 43:100, respectively. The respective ratios for fal1 1974 were 53:100 and 40:100. These compare closely with those reported for the Bu11 Mountains during the same period in 1973 (Dusek and McCann 1974) and those in the Missouri breaks and Little Belt Mountains (Mackie 1970, Coop 1971, and Day 1973).

Observations of yearling, or "spike" males decreased from summer to fall while those of older bulis increased. Coop (1971) reported a similar occurrence in the Little Belt Mountains. This occurrence was perhaps related to breeding activity which appeared to commence during late August. 
Table 17. Population characteristics of elk as determined from 322 ground and aerial observations during summer and fall 1974.

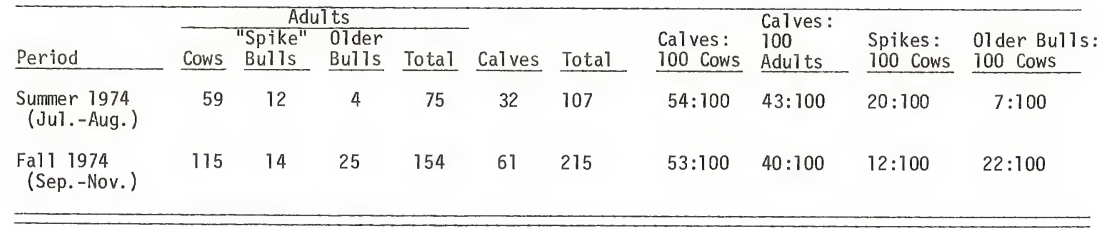




\section{Turkeys}

Since their introduction in 1958, Merriam's turkey has become one of the more popular game animals in the Bull Mountains. Based on harvest data from hunter questionnaires (Compton 1974), the greatest number of turkey hunters and the greatest harvest of turkeys in region 5 , since 1962, has occurred in Musselshell County. Hunter success during fall 1973 was 39 percent, slightly higher than the 1962-72 average. Until 1974, there had never been a spring gobbler season in Musselshell County. During that spring 20 permits were issued for a gobbler season on property owned and leased by Consol. Three turkeys were reported killed during that special season.

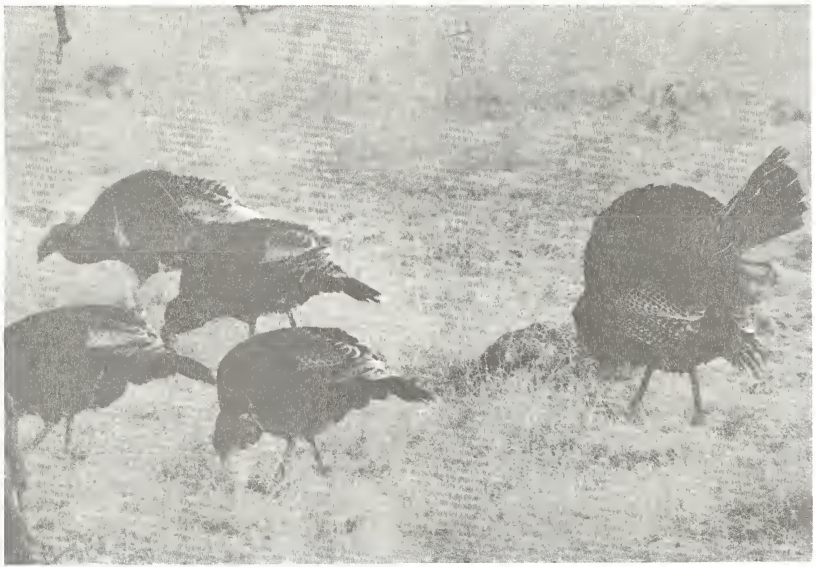

Distribution and Range Use

Distribution and range use data during the report period were based on 545 observations of turkeys. Most observations were obtained from ground surveys and supplemented with aerial observations.

\section{Distribution}

The yearlong distribution of turkeys in the Bull Mountains was illustrated in the initial progress report (Dusek and McCann 1973). 
Most observations during this report period occurred in that same general area, mostly in southern Musselshell County. Some observations were made along the northern edge of Yellowstone County. Turkeys may occur as far west as Golden Valley County, although observations have not been obtained west of Dewey Creek (Figure 1). Turkeys were dispersed throughout the side drainages and foothills during summer and fall, but appeared to be concentrated along major drainages during winter and early spring.

\section{Flocking Characteristics}

Flocking data for the report period appear in Table 18. The general yearlong trend is similar to that reported during previous years (Dusek and McCann 1973 and 1974) and that reported for the Long Pines in southeas tern Montana (Jonas 1966).

Gobbler flocks were observed during all seasons, but were largest in number during fall and winter when these flocks averaged 5 and $29 /$ group, respectively (Table 18). Solitary hens were observed only during spring which was perhaps related to nesting activity. During other seasons hens were associated with some type of flock. Brood flocks, each containing from one to three hens, were observed during summer and early fall. Jonas (1966) indicated that individual broods combined when poults were 7 to 10 days old. During this report period mixed flocks were observed during winter and early spring. During April mixed flocks gave way to courtship flocks which contained from one to four displaying males and averaged five and three total birds/group during spring and early summer, respectively.

\section{Use of Vegetation Types}

Spring: During spring 1974, the grass land type accounted for 44 percent of the seasonal use, most of which occurred in the drainageway subtype (Table 19). The ponderosa pine-grassland and agricultural types received 25 and 19 percent of the seasonal use, respectively. The ponderosa pine-bunchgrass and hay meadow subtypes received the greatest use within their respective types. The pattern of use of vegetation types by turkeys during spring 1974 was similar to that reported for the previous spring (Dusek and McCann 1974).

Summer: Seventy-five percent of the observations during summer 1974 occurred in the grassland type. As opposed to data gathered during spring, most observations in this type occurred in the grassland park subtype (Table 19). The ponderosa pine-grassland and agricultural types also received some use during this season.

Fal1: Due to the small number of birds observed during this season, the data in Table 19 may not accurately reflect the seasonal preference by turkeys for vegetation types during fall 1974 . During this season 76 and 24 percent of the observations occurred in the grassiand and ponderosa pine types, respectively. 
Table 18. Seasonal flocking habits of turkeys based on 545 observations of turkeys during the report period.

\begin{tabular}{|c|c|c|c|c|c|c|c|c|c|c|c|c|}
\hline & $\begin{array}{c}\text { Spring } \\
\text { No. }\end{array}$ & $\begin{array}{r}1974 \\
\mathrm{Fl} .\end{array}$ & $\begin{array}{c}(171) 1 / \\
\text { Avg. }\end{array}$ & $\begin{array}{l}\text { Summer } \\
\text { No. }\end{array}$ & $\begin{array}{c}r 1975 \\
\text { F1. }\end{array}$ & $\begin{array}{l}\text { (106) } \\
\text { Avg. } \\
\end{array}$ & $\begin{array}{l}\text { Fal } \\
\text { No. } \\
\end{array}$ & $\begin{array}{c}11974 \\
\mathrm{~F} 1 . \\
\end{array}$ & $\begin{array}{l}(8) \\
\text { Avg. } \\
\end{array}$ & $\begin{array}{c}\text { Winter } \\
\text { No. }\end{array}$ & $\begin{array}{l}\text { 1974-75 } \\
\text { F1. }\end{array}$ & $\begin{array}{l}75(230) \\
\text { Avg. } \\
\end{array}$ \\
\hline Gobbler & 37 & 12 & 3 & 44 & 10 & 4 & 14 & 3 & 5 & 29 & 1 & 29 \\
\hline Hen & 1 & 1 & 1 & - & - & - & - & - & - & - & - & - \\
\hline Brood & - & - & - & 52 & 4 & 13 & 24 & 1 & 24 & - & - & - \\
\hline Mixed & 79 & 5 & 16 & - & - & - & - & - & - & 201 & 7 & 29 \\
\hline Courtship & 54 & 10 & 5 & 10 & 3 & 3 & - & - & - & - & - & - \\
\hline
\end{tabular}

1/ Sample size for a respective season 
Table 19. Seasonal use of vegetation types and subtypes by turkeys as determined from 545 ground and aerial observations during the report period.

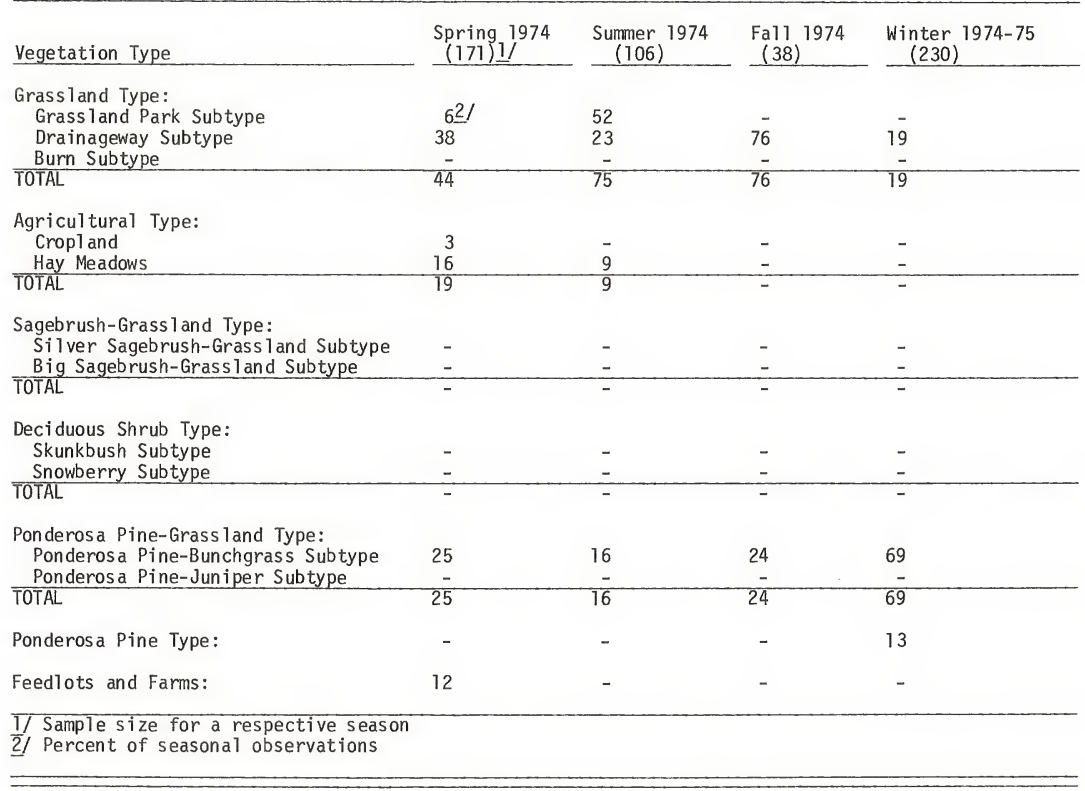




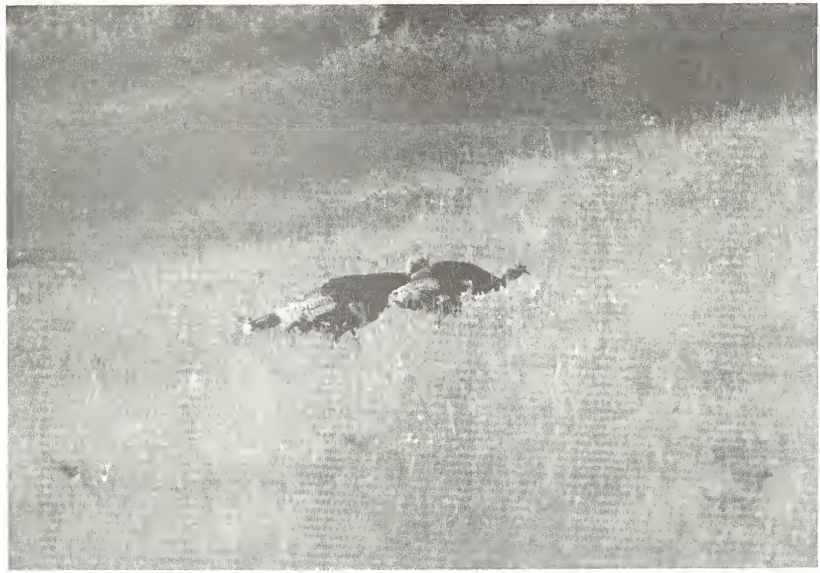

Winter: During winter 1974-75, 69 percent of the recorded use occurred in the ponderosa pine-grassland type, all of which occurred in the ponderosa pine-bunchgrass subtype. The grass 1 and and ponderosa pine types accounted for 19 and 13 percent of the seasonal use, respectively. No use was recorded in feedlots, farmsteads, or in the agricultural type. These findings are in contrast to those reported for the three previous winters (Dusek and McCann 1973 and 1974). There appeared to be an abundant mast crop from ponderosa pine during the growing season of 1974 . Data from the Long Pines of southeastern Montana indicated an apparent preference for pine seeds when available. This may be the reason why turkeys were not observed in feedlots and in the agricultural type during this winter even though climatic conditions were more severe than during the two previous winters.

\section{Relation to Timber}

Merriam's turkey is basically associated with ponderosa pine, al though its habitat is not 7 imited to that vegetation type (MacDonald and Jantzen 1967). During the report period turkeys invariably used stands of ponderosa pine for escape cover. In addition to escape cover, the mast from ponderosa pine provides an important food source for turkeys, and certain classes of trees are used as roosting sites. Results from a 
study in Colorado indicated a preference for roost sites that contained mature and overmature trees devoid of branches near the ground, with large horizontal branches, and occurring in relatively open canopies (Boeker and Scott 1969). In the Long Pines, trees in the mature sawlog class received the greatest use (Jonas 1966). Most of these sites occurred on sheltered slopes facing south or southeast.

During spring and summer 1974, 95 and 84 percent of the respective observations of turkeys were within 300 feet of the nearest stand of timber (Table 20). During the following fall and winter, all observations were within 100 feet of the nearest stand of timber. This pattern was perhaps related to the yearlong trend in use of vegetation types.

Table 20. Occurrence of turkeys at various distances from the nearest stand of timber as determined from 499 ground and aerial observations during the report period.

\begin{tabular}{|c|c|c|c|c|}
\hline Distance Class & $\begin{array}{l}\text { Spring } 1974 \\
(125) 1 / \\
\end{array}$ & $\begin{array}{c}\text { Summer } 1974 \\
(106) \\
\end{array}$ & $\begin{array}{c}\text { Fal } 13974 \\
(38) \\
\end{array}$ & $\begin{array}{c}\text { Winter 1974-75 } \\
(230)\end{array}$ \\
\hline $\begin{array}{l}0-100 \mathrm{ft} . \\
100-300 \mathrm{ft} . \\
300-600 \mathrm{ft} . \\
\text { Over } 600 \mathrm{ft} .\end{array}$ & $\begin{array}{l}4821 \\
47 \\
6 \\
-\end{array}$ & $\begin{array}{r}66 \\
18 \\
7 \\
9\end{array}$ & $\begin{array}{r}100 \\
- \\
- \\
-\end{array}$ & $\begin{array}{r}100 \\
- \\
- \\
-\end{array}$ \\
\hline
\end{tabular}

I/ Sample size for a respective season

2) Percent of seasonal observations

\section{Use of Slopes}

Seasonal use by turkeys of the six classes of topographical features appears in Table 21. During spring 1974, 65 percent of the observations occurred on flatlands (Table 22). This was influenced largely by observations occurring on plateaus and in coulee bottoms. Gentle slopes received the greatest use during other seasons increasing from 55 percent of the observations during summer 1974 to 88 percent during winter 1974-75. Turkeys were not observed on steep slopes during the report period.

\section{Population Characteristics}

Ten broods, which included 66 poults, were observed from July through September 1974. Average brood size was 6.6 poults per brood (Table 23). The average number of poults per female and poults per adult were 6.6 and 1.0 , respectively. Except during winter, the number of adult males observed exceeded females. For this reason the number of poults per adult may have been underestimated. Even with this in mind, 50 percent of the 
Table 21. Seasonal use of the various topographical features by turkeys as determined from 545 ground and aerial observations during the report period.

\begin{tabular}{|c|c|c|c|c|c|c|}
\hline Season & Sidehill & $\begin{array}{l}\text { Coulee } \\
\text { Bottom }\end{array}$ & $\begin{array}{l}\text { Creek } \\
\text { Bottom }\end{array}$ & Ridge & Plateau & $\begin{array}{l}\text { Coulee } \\
\text { Head }\end{array}$ \\
\hline $\begin{array}{l}\text { Spring } 1974(171) \text { ]/ } \\
\text { Summer } 1974(106) \\
\text { Fal1 1974(38) } \\
\text { Winter 1974-75 (230) }\end{array}$ & $\begin{array}{l}27 \underline{2}- \\
59 \\
76 \\
67\end{array}$ & $\begin{array}{r}25 \\
13 \\
13 \\
-\end{array}$ & $\begin{array}{l}1 \\
3 \\
- \\
-\end{array}$ & $\begin{array}{r}- \\
8 \\
\overline{1} \\
\end{array}$ & $\begin{array}{r}26 \\
17 \\
- \\
- \\
\end{array}$ & $\begin{array}{r}21 \\
10 \\
22\end{array}$ \\
\hline
\end{tabular}

1/ Sample size for a respective season

$\overline{2}$ / Percent of seasonal observations

Table 22. Seasonal use of gradients by turkeys during the report period.

\begin{tabular}{|c|c|c|c|c|}
\hline Gradient & $\begin{array}{c}\text { Spring } 1974 \\
(147) 1 / \\
\end{array}$ & $\begin{array}{l}\text { Summer } 1974 \\
(106)\end{array}$ & $\begin{array}{l}\text { FarT } 1974 \\
(38)\end{array}$ & $\begin{array}{l}\text { Winter 1974- } \\
(230) \\
\end{array}$ \\
\hline Flat? & $65 \underline{3} /$ & 42 & 13 & 12 \\
\hline $\begin{array}{l}\text { Gentle } \\
\left(0-15^{\circ}\right)\end{array}$ & 13 & 55 & 74 & 88 \\
\hline $\begin{array}{l}\text { Medium } \\
(76-300)\end{array}$ & 22 & 3 & 13 & - \\
\hline $\begin{array}{l}\text { Steep } \\
(37-450)\end{array}$ & - & - & - & - \\
\hline $\begin{array}{ll}\frac{1 /}{2 /} \text { Season } \\
\frac{\text { Incluo }}{3 /} \text { Percen }\end{array}$ & $\begin{array}{l}\text { size } \\
\text { bottoms, } \\
\text { nal sample }\end{array}$ & (t) & and $p$ & \\
\hline
\end{tabular}

Table 23. Population characteristics of turkeys during the period JulySeptember 1974 based on 130 observations.

\begin{tabular}{|c|c|c|c|c|c|c|c|c|}
\hline Period & No. & No. & $\begin{array}{l}\text { Avg. } \\
\text { Brood }\end{array}$ & & Adult & & Young: & Young: \\
\hline Covered & Broods & Young & & $\underline{M}$ & $\underline{F}$ & Totals & Adult F. & Adult \\
\hline $\begin{array}{l}\text { July- } \\
\text { September } 1974\end{array}$ & 10 & 66 & 6.6 & 54 & 10 & 64 & $6.6: 1$ & $1.0: 1$ \\
\hline
\end{tabular}


turkeys observed during the July-September period were birds of the year. The number of poults per brood and poults per female was higher than the respective figures for the previous two years (Dusek and McCann 1973 and 1974).

\section{Pronghorn}

Distribution and population data concerning pronghorn antelope during the report period were obtained from aerial surveys during July 1974. Observations of this species in the Bull Mountains during fall and winter were rare.

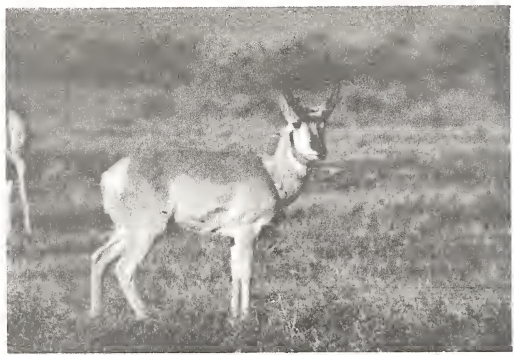

Distribution

During the report period data were gathered only in hunting district 540. Most observations were obtained in the Buffalo Creek and Railroad Creek drainages in northern Yellowstone County. That area was characterized by rolling topography with big sagebrush-grasslands and grasslands interspersed with timbered ridges. Fewer observations of pronghorn were obtained in southern Musselshell County which was characterized by rougher topography and more timber than occurred in Yellowstone County. The distribution of pronghorn followed a pattern similar to that observed during the previous summer (Dusek and McCann 1974).

\section{Population Characteristics}

Fawn: doe and fawn:adult ratios for hunting district 540 during July 1974 were 25:100 and 17:100 based on a sample of 164 animals (Table 24). These production figures were less than those reported for the previous summer (Dusek and McCann 1974). 
Table 24. Population characteristics of pronghorn as determined from 164 aerial observations in hunting district 540 during July 1974.

\begin{tabular}{|c|c|c|c|c|c|c|c|c|}
\hline Period & Does & $\begin{array}{l}\text { Adult } \\
\text { Bucks } \\
\end{array}$ & Tota & Fawns & Total & $\begin{array}{l}\text { Fawns: } \\
100 \text { Does }\end{array}$ & $\begin{array}{l}\text { Fawns: } \\
100 \text { Adu1ts }\end{array}$ & $\begin{array}{l}\text { Bucks: } \\
100 \text { Does }\end{array}$ \\
\hline July 1974 & 95 & 45 & 140 & 24 & 164 & $25: 100$ & $17: 100$ & $47: 100$ \\
\hline
\end{tabular}

Rest-Rotation Grazing Study

The principles and benefits of grazing management systems have been outlined by Hormay (1970) and Wambolt (1973). The following proposal contains our recommendations concerning implementation of a rest-rotation grazing system on the Brown Ranch, now owned by Consol. Technical assistance was provided by the Soil Conservation Service, USDA (SCS), which included a range survey to determine stocking rates and a general plan for a threepasture rest-rotation system. Use of the ranch unit by livestock and mule deer was discussed briefly in the initial report (Dusek and McCann 1973).

This phase of study was undertaken with the following objectives: (1) to study the effects of a systematic grazing program in the Bull Mountains on general range condition and habitat use by game populations, and (2) to develop criteria that may aid in successful reclamation of spoils following surface mining.

\section{Rest-Rotation Grazing System}

Range units A, B and C (Figure 7), which include 12,282 acres, would be grazed by cattle under a three-pasture rest-rotation system. The suggested initial stocking rate was 540 animal unit months (AUM's) for each range unit, or a total of 1620 AUM's for the three-pasture system. The system was planned for implementation on May 1, 1976 after the next lease period begins. The grazing season would last 6 months with an initial stocking rate of 270 cow/calf units or 378 yearlings.

On May 1 all cattle would be turned into one unit to graze until seed-ripe of the management grasses, green needlegrass (Stipa viridula) and western wheatgrass (Agropyron smithii) - approximately August 1. On August 1 gates to the second unit would be opened so that cattle would have access to both units. After approximately 2 weeks, cattle remaining in the first unit would be moved to the second unit and gates would be closed. This treatment should accomplish trampling of ripe seeds. Cattle would remain in the second unit until November 1 when they would be removed from the system area. The third unit would receive no grazing. This would allow for: (1) the opportunity for plants to make and store food and build up vigor, (2) a chance for seed to ripen, (3) seedling establishment, and (4) accumulation of residual vegetation. The schedule of the three treatments during the three-year cycle appears in Table 25. 
CONSOL UNIT:
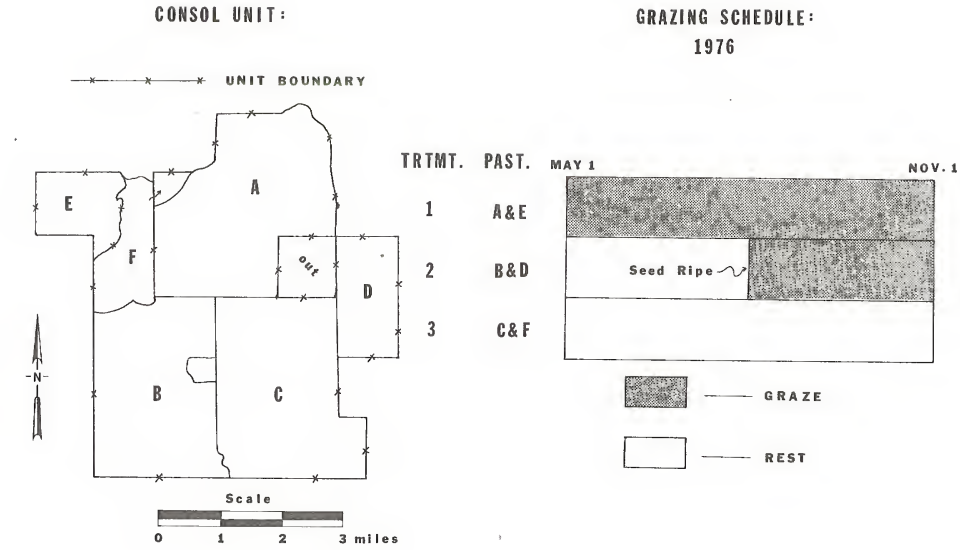

Figure 7. Treatment pastures on Consol's ranch (1eft) and the rest-rotation grazing system (right). 
Table 25. Schedule of grazing treatments for two three-pasture restrotation allotments for one 3-year cycle.

$$
\begin{aligned}
1976 \text { - } & \text { May 1 - August 1 } \\
& \text { August } 1 \text { - November } 1 \\
& \text { Rest - no grazing } \\
1977 \text { - } & \text { May 1 - August 1 } \\
& \text { August } 1 \text { - November } 1 \\
& \text { Rest - no grazing } \\
1978 \text { - } & \text { May 1 - August 1 } \\
& \text { August 1 - November 1 } \\
& \text { Rest - no grazing }
\end{aligned}
$$
Units $A$ and $E$
Units $B$ and $D$
Units $C$ and $F$
Units $C$ and $F$
Units $A$ and $E$
Units $B$ and $D$
Units $B$ and $D$
Units $C$ and $F$
Units $A$ and $E$

\section{Grazing Management for Remainder of Ranch}

The remaining 3324 acres, not included in the large three-pasture system, occur at the east end of the ranch and at the west end along Fattig Creek. Included are units D, E and F (Figure 7), which contain 1280,948 and 1076 acres, respectively. Approximately 509 AUM's are available for the three units combined. The initial stocking rate would be $60 \mathrm{cow} / \mathrm{calf}$ units or 83 yearlings. The grazing schedule for this smaller three-pasture system also appears in Table 25.

Units $E$ and $F$ occur along Fattig Creek. Unit $D$ occurs on the east end of the ranch and will receive the same treatment during the 3-year cycle as unit $B$ in the large system. The rationale is as follows: unit $D$, as well as units $A$ and $C$, receive considerable use by elk during the winter-spring period. Under this schedule, one of these three contiguous pastures (Figure 7) would receive complete rest from livestock each year.

\section{Management Benefits}

During years of scheduled rest, drainages and other natural openings in the timber canopy that normally receive heavy grazing pressure from livestock under continuous grazing practices will have ungrazed forage and a total absence of livestock 1 out of every 3 years. This should improve range condition in general, and, more specifically, make such areas more habitable for wildlife.

The entire ranch will receive no use by livestock during the critical period of November through April. An adequate harvest of big game animals would be necessary to maintain game populations in balance with available forage. Long-term goals of such a management program are: (1) improved range conditions, and (2) a balanced use of the range by iivestock and wildlife. 
This phase of study included monitoring vegetational development and composition and use by wildlife on small acreages that have undergone mining, grading and application of seed and fertilizer. Up to the present time, this has been done at two sites which include consol's test pit and the Square Deal pit southeast and northwest of Roundup, respectively (Figure 1). The respective areas affect 12 and 7 acres.

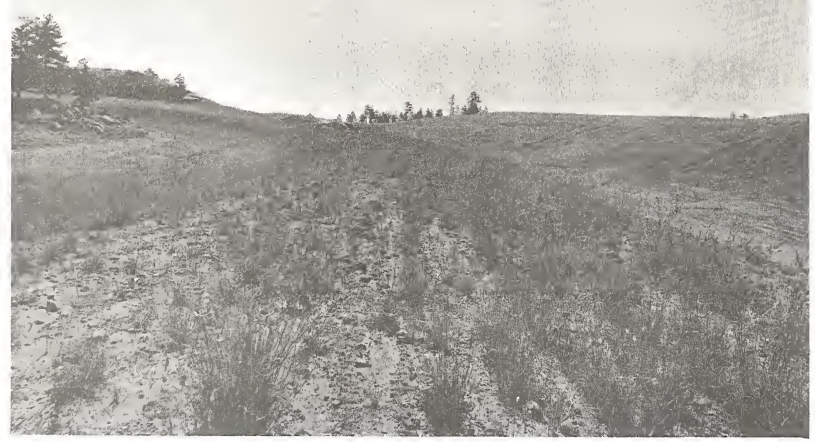

\section{Consol's Test Pit}

Overburden was removed and coal was extracted at this site during August 1971. Grading was completed during December 1971, and application of seed and chemical fertilizer were completed during May 1972 . The rationale of the reclamation plan and vegetational composition during the first two growing seasons following seeding were discussed in previous reports (Dusek and McCann 1973 and 1974). Some portions were reworked, mulched and reseeded during fall 1974. Approximately 2500 ponderosa pine (Pinus ponderosa) seedlings are scheduled for planting on those sites during spring 1975. Results of this will appear in a later report. 
Vegetational Analysis

Two additional transect sites were placed, both on the north highwall, during the report period. These, in addition to the 17 established during the previous 2 years, were read during July 1974 (Figure 8). Each of these permanent sites was analyzed by a canopy coverage method (Daubenmire 1959) whereby $202 \times 5$ decimeter plots were sampled at each site along a 100 foot transect line. Transect lines were placed parallel to the contour when practicable and the site marker was used as a midpoint. Seven coverage classes were used to estimate the percent of bare ground, rock, litter and canopy coverages of vegetation by forage class and species.

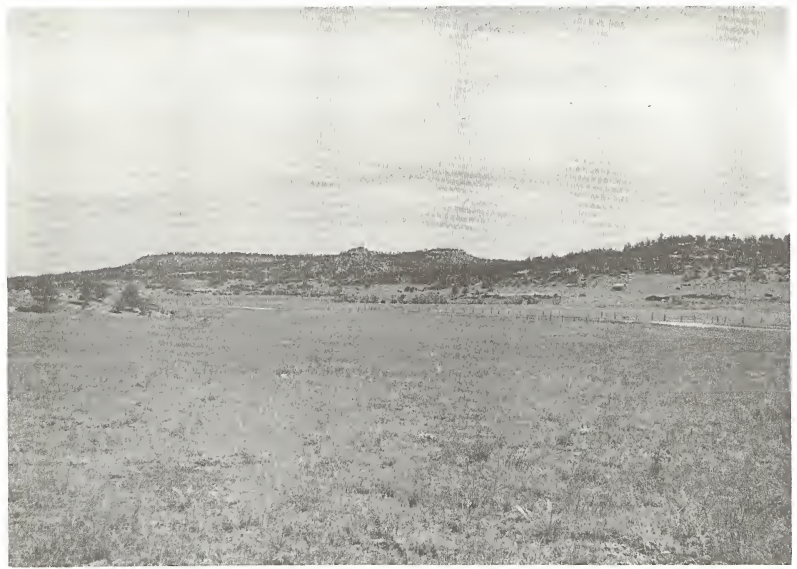

\section{Soil Mixture}

The following analysis compares data by soil mixture, regardless of gradient or exposure. Data appear in Table 26. Comparison of the relative abundance of bare ground, litter, grasses and forbs during the growing seasons of 1972-74 is shown in Figure 9.

Topsoil: Topsoiled sites exhibited the greatest canopy of living and residual vegetation and the greatest diversity of plant species of all soil types during 1974 (Table 26). An increase in the canopy of 


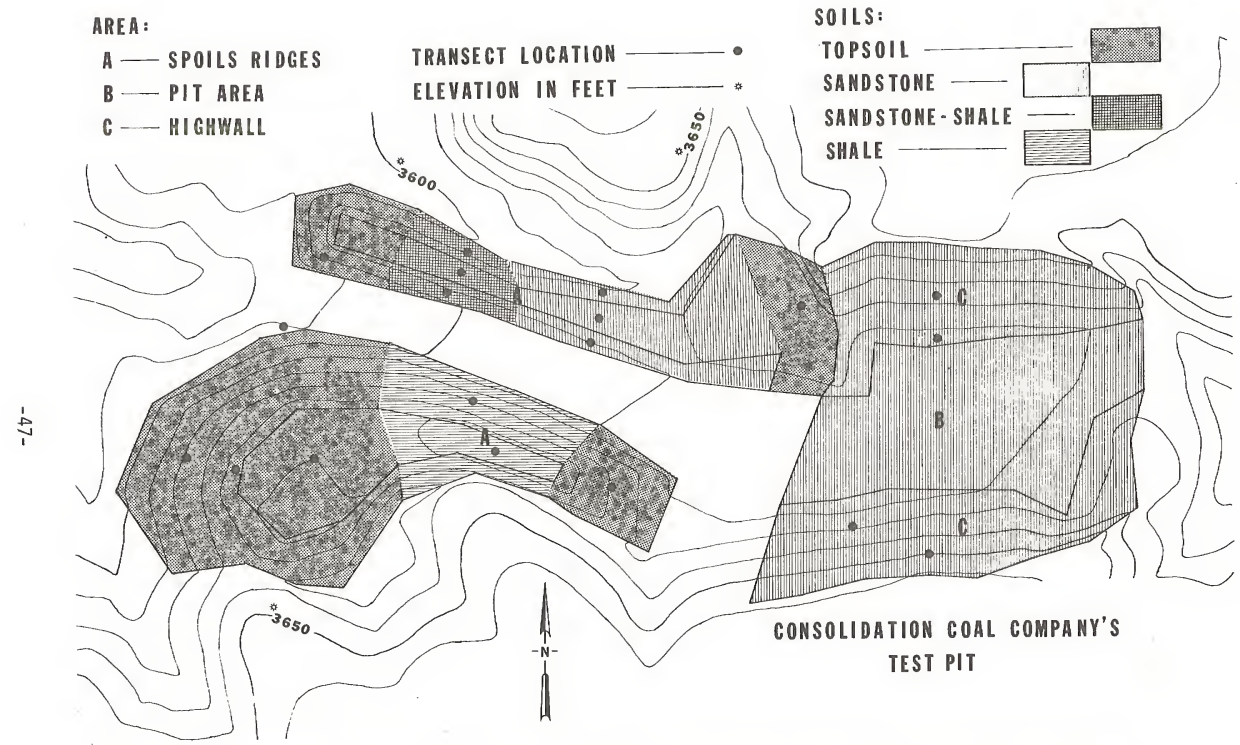

Figure 8. Respective areas, soil mixtures and the location of 19 permanent vegetational analysis sites at Consol's test pit from 1972 to 1974. 
Table 26. Constancy, canopy coverage and frequency of low-growing vegetation on various types of soil on spoils material as determined by examination of $202 \times 5$ decimeter plots on each of 19 sites at Consol's test pit.

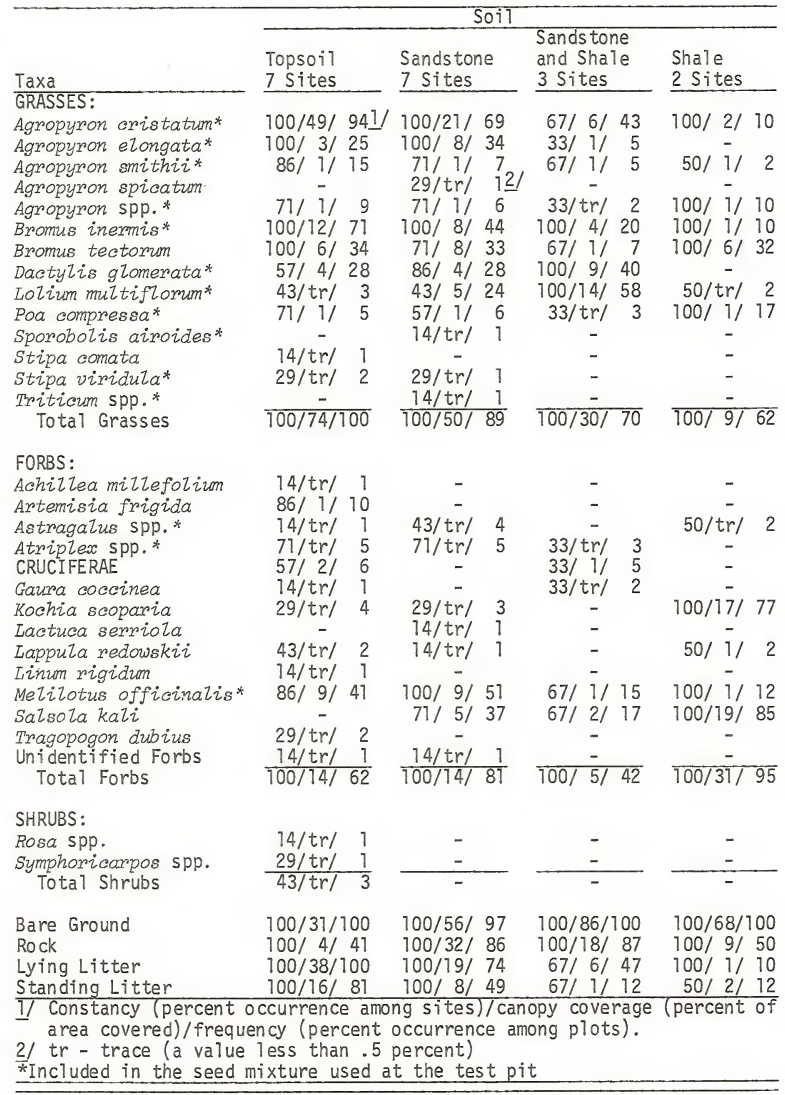




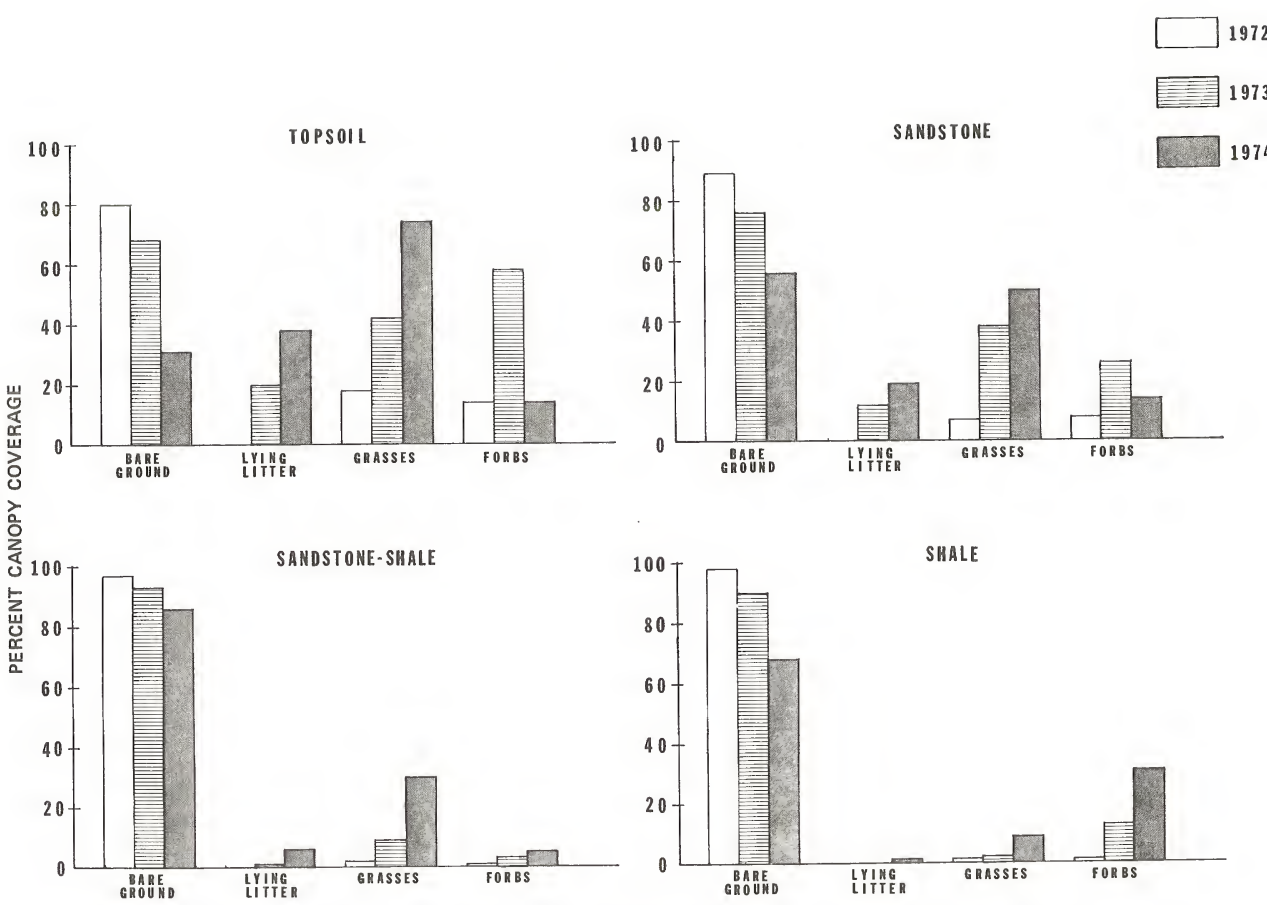

Figure 9. Changes in cover of bare ground, litter, grasses and forbs on various soil mixtures at Consol's test pit from 1972 to 1974 . 
grasses and a decrease in that of forbs from 1973 to 1974 appeared directly related to the respective increase and decrease in the canopy of crested wheatgrass (Agropyron cristatum) and yellow sweetclover (Melizotus officinalis) the most abundant grass and forb, respectively (Figure 9). A slight increase in the canopy of cheatgrass (Bromus tectorum) was noted, while western wheatgrass showed a marked decrease from 1973 to 1974 . The canopy of other grasses appeared to change very little between the 2 years. Shrubs, which included wild rose and snowberry, occurred only on topsoiled portions, and did not appear to have increased from previous growing seasons (Table 26).

Sandstone: Although the total cover of grasses was less than that which occurred on topsoil, sandstone exhibited the same year-to-year trend in relative abundance of grasses and forbs (Figure 9). On sandstone sites crested wheatgrass was also by far the most abundant grass species, as well as the most abundant single species that occurred. It increased from a canopy of 10 percent in 1973 to 21 percent in 1974 on sandstone sites. The canopy of other grasses appeared to change very little, if at all, from 1973 to 1974. Tall wheatgrass (A. elongata) was evident on all sandstone sites during 1974. The total canopy of forbs, 14 percent, was the same as that recorded on topsoiled sites. Yellow sweetclover and Russian thistle (Salsola kali) accounted for most of the forb cover on sandstone (Table 26).

Sandstone-Shale: The canopy of living vegetation on this mixture was considerably less than that which occurred on topsoil and sands tone (Table 26). A marked increase in the canopy of grass and a slight increase in forbs occurred from 1973 to 1974 (Figure 9). Ryegrass (Lolium multiflorum) was the most abundant grass as well as the single most abundant species. It exhibited a marked increase in canopy on these sites over the previous year. The total forb canopy on sandstone-shale sites was 5 percent during this report period. No one forb species predominated (Table 26).

Shale: This was the only type of soil on the disturbed area that exhibited a greater canopy of forbs than grasses during 1974 (Table 26). The total forb canopy on these sites nearly tripled that reported for the same period during 1973 (Figure 9). Russian thistle and summer cypress (Kochia scoparia) accounted for the bulk of the canopy of forbs. Cheatgrass was the most abundant grass.

\section{Gradient}

When data gathered during 1974 were combined according to gradient, regardless of soil mixture or exposure, sites varying from 2.5:1 to $3: 1$ (medium) exhibited the greatest canopy of grasses and residual vegetation while sites varying from 1.25:1 to 2:1 (steep) exhibited the lowest (Table 27). Ryegrass was the most abundant grass on steep gradients, whereas crested wheatgrass was by far the most abundant on those that were medium or nearly level. The canopy of grasses increased from 1972 to 1974 on all three classes of gradient (Figure 10).

Although the canopy of grasses exceeded that of forbs on all three classes of gradient, sites having a steep gradient exhibited the greatest canopy of forbs of which Russian thistle was the most abundant (Table 27). Yellow sweetclover was the most abundant forb on medium and nearly level 
Table 27. Constancy, canopy coverage and frequency of low-growing vegetation on various classes of gradient on spoils material as determined by examination of $202 \times 5$ decimeter plots on each of 19 sites at Consol's test pit.

\begin{tabular}{|c|c|c|c|}
\hline Taxa & $\begin{array}{l}1.25: 1-2: 1 \\
6 \text { Sites }\end{array}$ & $\begin{array}{c}\text { Slope } \\
2.5: 1-3: 1 \\
7 \text { Sites }\end{array}$ & $\begin{array}{l}\text { Nearly Level } \\
6 \text { Sites }\end{array}$ \\
\hline GRASSES: & & & \\
\hline $\begin{array}{l}\text { Agropyron cristatum* } \\
\text { Agropyron elongata* }\end{array}$ & $\begin{array}{l}83 / 8 / 341-1 \\
67 / 2 / 13\end{array}$ & $\begin{array}{l}100 / 38 / 86 \\
100 / 8 / 35\end{array}$ & $\begin{array}{r}100 / 33 / 82 \\
67 / 2 / 17\end{array}$ \\
\hline Agropyron smithii* & $33 / \operatorname{tr} / 22 /$ & $86 / 1 / 11$ & $100 / 1 / 13$ \\
\hline Agropyron spicatum & & $29 /$ tr/ 1 & \\
\hline Agropyron spp.* & $50 / 1 / 2$ & $100 / 1 / 11$ & $50 / 1 / 6$ \\
\hline Bromus inermis* & $100 / 4 / 22$ & $100 / 11 / 61$ & $100 / 8 / 54$ \\
\hline Bromus tectorum & $67 / 5 / 22$ & $100 / 9 / 46$ & $83 / 2 / 15$ \\
\hline Dactylis glomerata* & $83 / 5 / 30$ & $57 / 1 / 17$ & $67 / 8 / 42$ \\
\hline Lolium multiflorum* & $83 / 10 / 35$ & $14 / \operatorname{tr} /$ & $67 / 3 / 25$ \\
\hline Poa compressa* & $67 / \operatorname{tr} / 5$ & $57 / 1 / 6$ & $67 / 1 / 8$ \\
\hline Sporobolis airoides* & & $14 / \mathrm{tr} / 1$ & 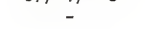 \\
\hline Stipa comata & $17 / 1 / 2$ & - & - \\
\hline Stipa viridula* & $17 / \operatorname{tr} / 2$ & $29 / \operatorname{tr} / 1$ & $17 / \mathrm{tr} / 1$ \\
\hline Triticum spp.* & $17 / \operatorname{tr} / 2$ & - & - \\
\hline Total Grasses & $\overline{100 / 31 / 69}$ & $100 / 64 / 98$ & $\overline{100 / 56 / 93}$ \\
\hline FORBS: & & & \\
\hline Achillea millefolium & $17 / \mathrm{tr} / 1$ & 2 & 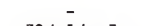 \\
\hline Artemisia frigida & $17 / \operatorname{tr} / 1$ & $29 / 1 / 5$ & $50 / 1 / 5$ \\
\hline Astragalus spp.* & $17 / \operatorname{tr} / 1$ & $43 / \operatorname{tr} / 3$ & $33 / \operatorname{tr} / 2$ \\
\hline Atriplex spp.* & $50 / 1 / 3$ & $71 /$ trl 5 & $50 / \operatorname{tr} / 4$ \\
\hline CRUCIFERAE & $33 / 7 / 6$ & $43 / 1 / 4$ & - \\
\hline Goura coccinea & $17 / \mathrm{tr} / 1$ & $14 /$ tr/ 1 & - \\
\hline Kochia scoparia & $50 / 5 / 20$ & $29 / \mathrm{tr} / 4$ & - \\
\hline Lactuca serriola & - & $14 / \mathrm{tr} / \quad 1$ & - \\
\hline Lappula redowskii & $17 / \operatorname{tr} / 1$ & $43 / t r / 2$ & - \\
\hline Linum rigidum & 等 & - & $33 / \operatorname{tr} / 10$ \\
\hline Melilotus officinalis* & $83 / 5 / 32$ & $86 / 9 / 44$ & $100 / 6 / 35$ \\
\hline Salsola kali & $67 / 8 / 44$ & $29 / 3 / 16$ & $50 / 1 / 17$ \\
\hline Tragopogon dubius & $17 / \operatorname{tr} / 2$ & ( & $17 / \mathrm{tr} / 1$ \\
\hline Unidentified Forbs & & & $17 / \mathrm{tr} / \quad 1$ \\
\hline Total Forbs & $100 / 19 / 77$ & $100 / 15 / 68$ & $100 / 10 / 62$ \\
\hline SHRUBS: & & & \\
\hline Rosa spp. & - & - & $17 / \mathrm{tr} /$ \\
\hline Symphoricarpos spp. & - & $14 / \mathrm{tr} / \quad 1$ & $17 / \mathrm{tr} / 1$ \\
\hline Total Shrubs & 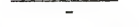 & $14 / \operatorname{tr} / 1$ & $33 / \operatorname{tr} / 2$ \\
\hline Bare Ground & $100 / 72 / 100$ & $100 / 40 / 97$ & $100 / 47 / 100$ \\
\hline Rock & $100 / 26 / 85$ & $100 / 20 / 61$ & $100 / 5 / 32$ \\
\hline Lying Litter & $83 / 8 / 46$ & $100 / 30 / 91$ & $100 / 26 / 77$ \\
\hline Standing Litter & $83 / 3 / 19$ & $100 / 14 / 69$ & $83 / 11 / 61$ \\
\hline $\begin{array}{l}\text { 1/ Constancy (percen } \\
\text { area covered)/fre } \\
\frac{2 / \text { tr - trace (a val }}{*} \text { Included in the se }\end{array}$ & $\begin{array}{l}\text { rrence amon } \\
\text { (percent } \\
s \text { than .5 p }\end{array}$ & $\begin{array}{l}\text { es)/canopy } \\
\text { ence among }\end{array}$ & ge (percent \\
\hline
\end{tabular}


sites. The canopy of forbs increased from 1972 to 1974 on steep sites as opposed to medium and nearly level sites where it reflected the phenology and abundance of yellow sweetclover, a biennial (Figure 10).

\section{Exposure}

Slopes having a northerly exposure exhibited a greater canopy of living and residual vegetation than did those that faced a southerly direction (Table 28). This general trend was the same during both 1973 and 1974 although the canopy of grasses increased and that of forbs decreased during that period (Figure 11). The differences in vegetational cover on northerly and southerly exposures perhaps reflects the more xeric conditions on southerly exposures which result from longer periods of direct sunlight throughout the year.

Use by Wildlife

\section{Game Species}

Mule deer used the test pit periodically throughout the report period. Evidence of this use included tracks and pellet groups. On two occasions during August 1974, sharp-tailed grouse were observed on the disturbed area.

During March 1974 a pellet group analys is (Neff 1968) was used to determine relative use among soil types by mule deer. This was facilitated by counting the number of pellet groups with in 2 feet on each side of a 100-foot transect line at each of 17 permanent vegetational analysis sites, thereby allowing a linear plot of 400 square feet to be sampled at each site. Pellet groups/400 square feet were converted to pellet groups/acre. The data reflected use of the area by deer during the previous year (March 1973-February 1974).

The average number of pellet groups/acre on topsoiled sites was 436 . The maximum number on any one topsoiled site was 980 and a minimum was zero. Sandstone sites averaged 196 pellet groups/acre with a maximum of 653 and a minimum of zero. No pellet groups were observed on sandstoneshale or shale sites.

During summer 1973, yellow sweetclover was quite abundant on the disturbed area (Dusek and McCann 1974). It was also the most abundant item in the diet of mule deer throughout the Bull Mountains during that summer. Its relative use as forage by mule deer is considered to be related to availability (Mackie 1970). Its abundance on topsoiled and sandstone sites may have made these areas attractive to deer during summer 1973. These conditions may have influenced pellet group density on topsoil and sandstone sites.

\section{Nongame Mammals}

The area encompassed by the test pit has been surveyed for nongame mammal activity since 1970. Movements and occurrence of nine species of nongame mammals were observed on the disturbed area (McCann 1975b). Also, census lines and winter track analysis methods were described in previous reports (Dusek and McCann 1973 and 1974). 
STEEP

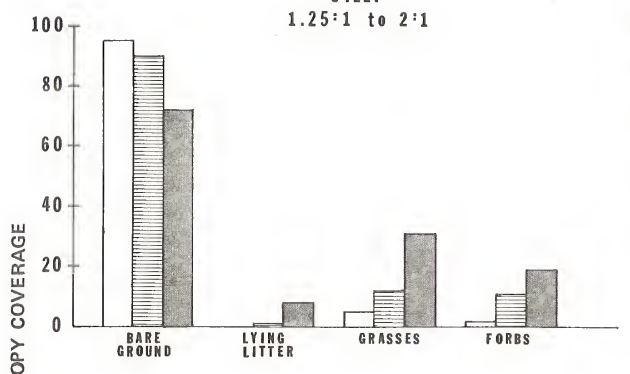

NEARLY LEVEL

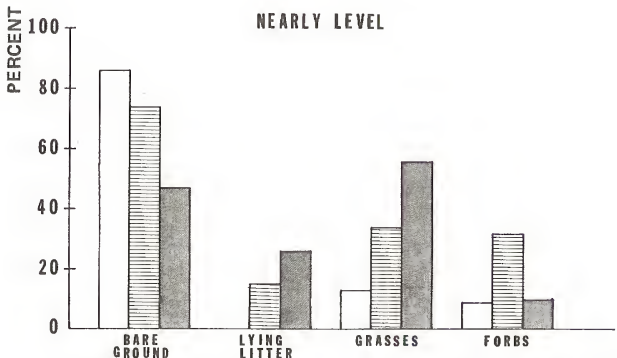

Figure 10. Changes in cover of bare ground, litter, grasses and forbs on various gradients at Consol's test pit from 1972 to 1974.

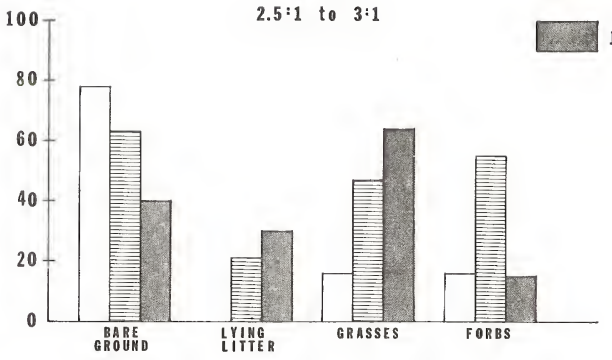

\section{4}


Table 28. Constancy, canopy coverage and frequency of low-growing vegetation on northerly and southerly exposures on spoils material as determined by examination of $202 \times 5$ decimeter plots on each of 14 sites at Consol's test pit.

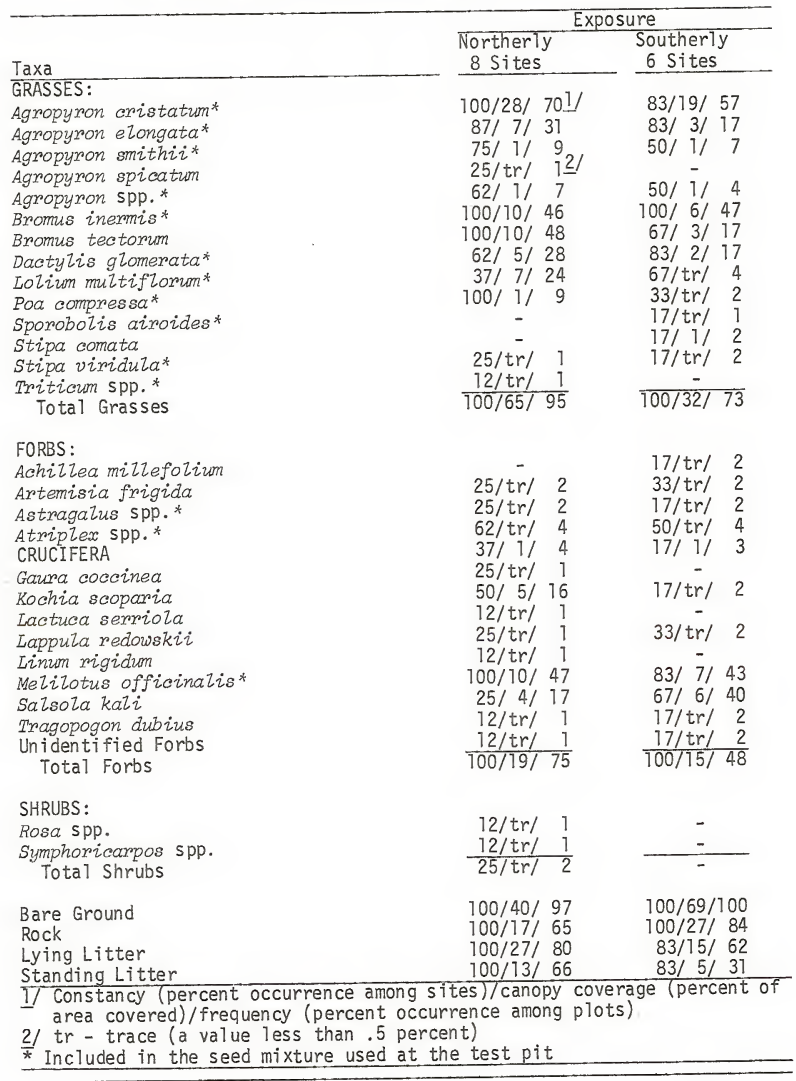



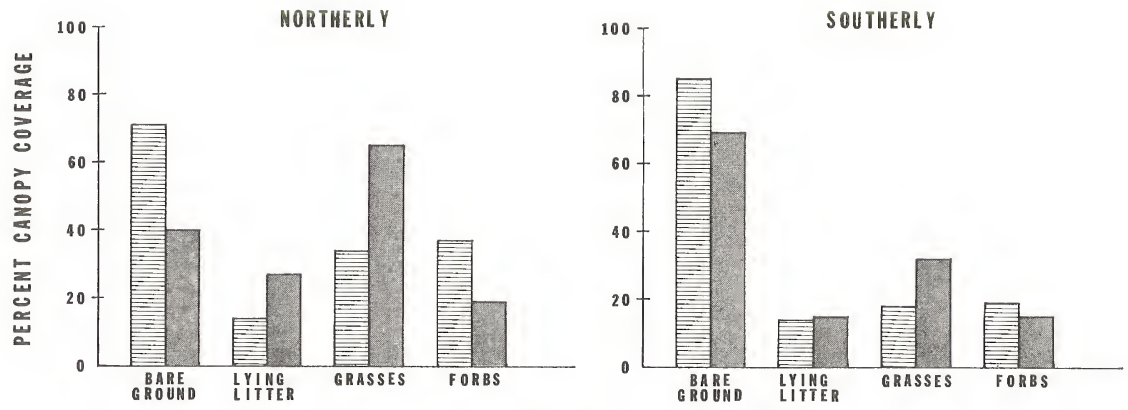

1973

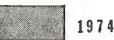

Figure 11. Changes in cover of bare ground, litter, grasses and forbs by aspect from 1972 to 1974 at Consol's test pit. 
During the summer of 1974, deer mouse (Peromyscus maniculatus osgoodii) population and home range data were obtained on the revegetated area. Population trends and movements of deer mice into disturbed portions of the test pit were discussed in a previous report (Dusek and McCann 1974). Census Tines $A$ and $E$, located on the undisturbed perimeter (Figure 12), exhibited a population index comparable to that reported for the surrounding undisturbed area (McCann 1974). However, this population index was less than that calculated on census lines B, C and D. Population indices on lines $B$ and $D$ have increased from 4 mice per 1,000 linear feet reported during 1973 (Dusek and McCann 1974) to 23 and 29 mice per 1,000 Tinear feet, respectively, during 1974 (Figure 13). During the summer of 1973, one male was trapped on census line C. Both breeding males and females were trapped on that 1 ine and a population index of 22 mice per 1,000 1 inear feet was obtained during 1974 (Figure 13).

Seven grids, each composed of 49 Sherman live traps, were placed on the spoils ridges and pit area during the summer of 1974 according to the pattern described by McCann (1975a). Each trap site was trapped for 10 days and nights. Traps were checked just after sunrise and again before dark. All trapped individuals were marked by toe-clipping. Home range sizes were determined according to Hayne (1949). Those individuals captured less than four times were excluded from compilations. The home ranges of deer mice are shown in Table 29 . Home ranges of mates were larger than those of females, especially during the breeding season. Getz (1961) has reported that care of young by females restricts activity. Also, breeding males may be actively searching for mates, which may result in larger home ranges.

Williams (1955) reported that mature males had home ranges of 0.52 acres and mature females 0.36 acres in a ponderosa pine community in northcentral colorado. Average home ranges of adult males and females in the test pit area were 0.51 and 0.43 acres, respectively.

The stomach content of 20 specimens of deer mice, randomly selected among the trap sites in the test pit, were analyzed during the report period according to a method described by Johnson (1961). By volume, grasshoppers and beetles were the main food items used by deer mice throughout the year (Table 30). A slight increase of grass seeds appeared to occur during winter, although specimens trapped during December 1974 were also feeding upon dormant insects.

During 1974, meadow voles (Microtus pennsyzvanicus insperatus) were captured for the first time on all topsoiled areas of the test pit. Vertz (1959) reported, from a study of animals on reclaimed areas, that changes in habitat related to increased height of vegetation may be sufficient to initiate mammal distribution changes. The occurrence of meadow voles within test pit areas may be the result of this change. Ingles (1967), Maser and Storm (1970) and Blair (1940) have indicated that Microtus species prefer dense vegetation. Meadow voles occupied areas of dense vegetation throughout the year in Musselshel1 County (Dusek and McCann 1974).

Meadow vole home ranges on test pit areas were determined by methods described for deer mice. Home ranges of males were larger than those of females (Table 31). 


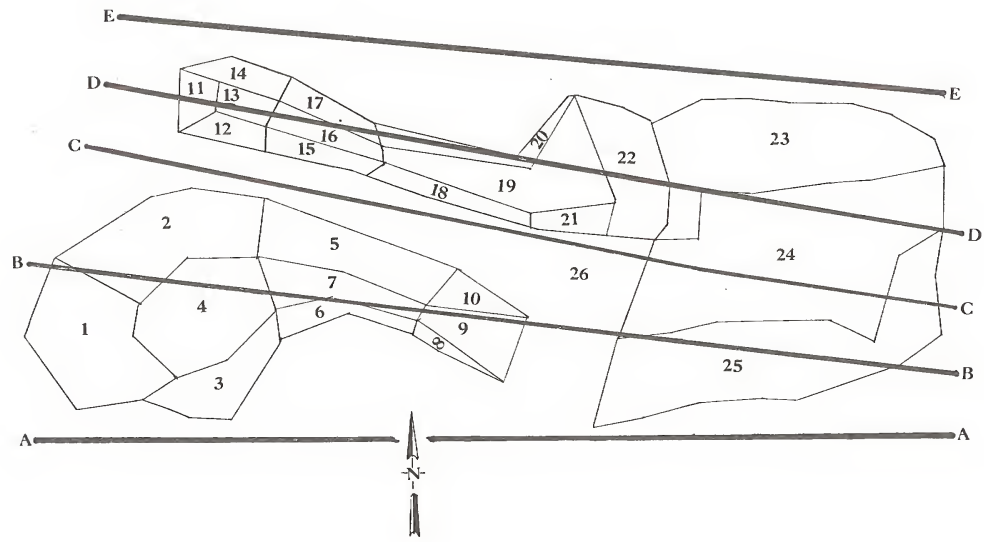

Figure 12. Summer census lines (lettered) and winter study areas (numbered). 


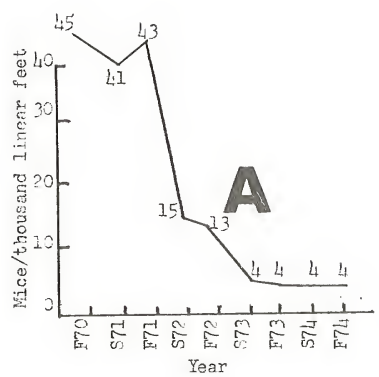

1
G
1

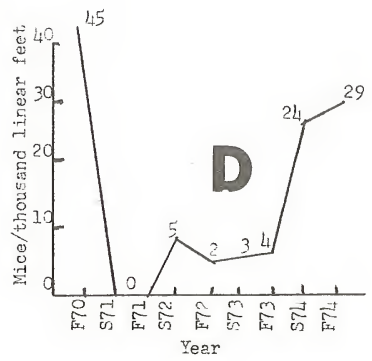

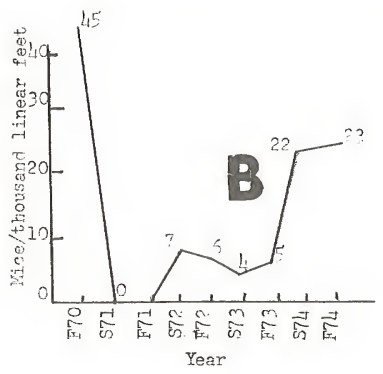

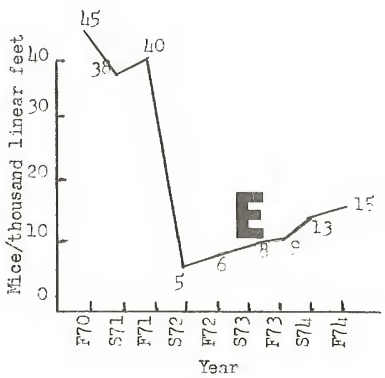

Fiqure 13. Deer mouse population trends at Consol's test pit. 
Table 29. Home range data for deer mice at Consol's test pit.

\begin{tabular}{|c|c|c|c|c|c|}
\hline \multirow{2}{*}{ 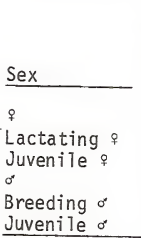 } & \multirow{2}{*}{$\begin{array}{l}\text { No. of } \\
\text { Specimens } \\
\text { Captured } \\
4 \text { Times } \\
12 \\
3 \\
8 \\
8 \\
5 \\
4 \\
\end{array}$} & $\begin{array}{l}\text { Total No. } \\
\text { of Specimens } \\
\text { Captured }\end{array}$ & $\begin{array}{l}\text { Home } \\
\text { Range } \\
\text { Acres }\end{array}$ & $\begin{array}{l}\text { Percent } \\
\text { of Totat } \\
\text { Poputation } \\
\text { Captured } \\
\end{array}$ & $\begin{array}{l}\text { Percent } \\
\text { of Total } \\
\text { Sex Captured } \\
\end{array}$ \\
\hline & & $\begin{array}{r}75 \\
13 \\
9 \\
46 \\
13 \\
7 \\
\end{array}$ & $\begin{array}{l}0.43 \\
0.40 \\
0.35 \\
0.51 \\
1.03 \\
0.25\end{array}$ & $\begin{array}{r}62 \\
11 \\
7 \\
38 \\
11 \\
6\end{array}$ & $\begin{array}{l}71 \\
17 \\
12 \\
60 \\
28 \\
12 \\
\end{array}$ \\
\hline $\begin{array}{l}\text { Total numbe } \\
\text { Total numbe } \\
\text { Number of } c \\
\text { Number of } f \\
\text { Number of } m\end{array}$ & $\begin{array}{l}r \text { of deer m } \\
r \text { of captur } \\
\text { aptures per } \\
\text { emales relo } \\
\text { ales reloca }\end{array}$ & $\begin{array}{ll}\text { ce captured - } \\
\text { s } \\
\text { mouse } \\
\text { ating } \\
\text { ing }\end{array}$ & $\begin{array}{l}121 \\
357 \\
2.9 \\
10 \\
5=\end{array}$ & $\begin{array}{l}8 \% \text { of popula } \\
4 \% \text { of popula }\end{array}$ & $\begin{array}{l}\text { ion }=13 \% \text { of } q \\
\text { ion }=11 \% \text { of } 0^{\circ}\end{array}$ \\
\hline
\end{tabular}

Blair (1940) reported that meadow vole home ranges, in a dry grass land community, were 0.48 acres for males and 0.16 acres for females. Calculated home ranges of males (adult and breeding combined), and females in the test pit were 0.46 and 0.13 acres, respectively.

The stomach contents of 20 randomly selected meadow voles trapped within the test pit area were analyzed during the report period following the procedure used for deer mice. By volume, grasses were the main food items used by meadow voles throughout the year (TabTe 32).

In order to study nongame mammat activity during winter, 26 numbered areas (Figure 12) were established on the test pit. Methods of calculating activity were described in previous reports (Dusek and McCann 1973 and 1974).

By activity, mammals more or Tess uniformly distributed throughout the test pit were cottontail rabbits, white-tailed jackrabbits and coyotes (Table 33). Most of these can be found upon a wide variety of habitats and they perhaps range over an area much Targer than the reclamation plot

Pocket gophers, ground squirrels, marmots and mice are limited in test pit usage by special unknown factors. Their limited distribution may be due to lack of cover, food, or both. 
Table 30. Deer mouse stomach analysis during summer and winter combined, Muss el she11 County.

\begin{tabular}{|c|c|c|c|c|}
\hline Stomach Contents & $\begin{array}{l}1973 \\
14 \\
\text { Specimens } \\
\end{array}$ & $\begin{array}{l}1974 \\
74 \\
\text { Specimens } \\
\end{array}$ & $\begin{array}{l}7973-74 \\
\text { Combined } \\
28 \\
\text { Specimens } \\
\end{array}$ & $\begin{array}{l}\text { Consol Test } \\
\text { Pit } 1974- \\
20 \\
\text { Specimens } \\
\end{array}$ \\
\hline $\begin{array}{l}\text { Insects: } \\
\text { Grasshoppers (ORTHOPTERA) } \\
\text { Spiders } \\
\text { Beetles (COLEOPTERA) } \\
\text { Misce11 aneous Cocoons } \\
\text { Miscellaneous Nymphs } \\
\text { Crickets } \\
\text { Ants } \\
\text { Unknown Insects }\end{array}$ & $\begin{array}{c}501 / \\
5 \\
10 \\
5 \\
- \\
- \\
- \\
10\end{array}$ & $\begin{array}{c}35 \underline{1 /} \\
- \\
6 \\
2 \\
5 \\
2 \\
- \\
10\end{array}$ & $\begin{array}{c}43^{1 /} \\
3 \\
8 \\
3 \\
3 \\
1 \\
- \\
10\end{array}$ & $\begin{array}{c}15-1 / \\
- \\
23 \\
- \\
- \\
2 \\
2 \\
4\end{array}$ \\
\hline $\begin{array}{l}\text { Grasses: } \\
\text { Stipa comata } \\
\text { Agropyron spp. } \\
\text { Dacty lis glomerata } \\
\text { Poa spp. } \\
\text { Unknown Grasses }\end{array}$ & $\begin{array}{l}2 \\
5 \\
- \\
1 \\
2\end{array}$ & $\begin{array}{r}4 \\
10 \\
- \\
2 \\
4\end{array}$ & $\begin{array}{l}3 \\
8 \\
- \\
2 \\
3\end{array}$ & $\begin{array}{l}- \\
6 \\
6 \\
\overline{3}\end{array}$ \\
\hline $\begin{array}{l}\text { Forbs: } \\
\text { Melilotus spp. } \\
\text { Rosa spp. } \\
\text { Unknown Forbs }\end{array}$ & $\begin{array}{l}5 \\
1 \\
3\end{array}$ & $\begin{array}{l}5 \\
- \\
8\end{array}$ & $\begin{array}{l}5 \\
1 \\
6\end{array}$ & $\begin{array}{r}8 \\
10\end{array}$ \\
\hline $\begin{array}{l}\text { Shrubs: } \\
\quad \text { Pine Seeds (PINUS) }\end{array}$ & - & 4 & 2 & - \\
\hline $\begin{array}{l}\text { Miscellaneous: } \\
\text { Hair } \\
\text { Unknown Roots }\end{array}$ & $\begin{array}{l}1 \\
1\end{array}$ & $\begin{array}{l}1 \\
1\end{array}$ & 1 & $\begin{array}{l}1 \\
9\end{array}$ \\
\hline Unidentified Material & 5 & 2 & 3 & 10 \\
\hline
\end{tabular}

1/ Percent volume of identifiable materials 
Table 31. Home range data for meadow voles at Consol's test pit.

\begin{tabular}{|c|c|c|c|c|c|}
\hline Sex & $\begin{array}{l}\text { No. of } \\
\text { Specimens } \\
\text { Captured } \\
4 \text { Times } \\
\end{array}$ & $\begin{array}{l}\text { Total No. } \\
\text { of Specimens } \\
\text { Captured }\end{array}$ & $\begin{array}{l}\text { Home } \\
\text { Range } \\
\text { Acres } \\
\end{array}$ & $\begin{array}{l}\text { Percent } \\
\text { of Total } \\
\text { Population } \\
\text { Captured } \\
\end{array}$ & $\begin{array}{l}\text { Percent } \\
\text { of Tota1 } \\
\text { Sex Captured }\end{array}$ \\
\hline q & 15 & 39 & 0.13 & 62 & 92 \\
\hline Lactating of & 3 & 3 & 0.14 & 5 & 8 \\
\hline & 4 & 24 & 0.23 & 38 & 58 \\
\hline Breeding o & 2 & 10 & 0.69 & 16 & 42 \\
\hline
\end{tabular}

Total number of meadow voles captured - 63

Total number of captures -134

Average number of captures per vole -2.13

Number of females relocating

Number of males relocating

$-2=3 \%$ of population $=5 \%$ of $q$

- $5=7 \%$ of population $=20 \%$ of $\sigma^{\circ}$

Table 32. Meadow vole stomach analys is during summer and winter combined, Musselshell County.

\begin{tabular}{|c|c|c|c|c|}
\hline Stomach Contents & $\begin{array}{l}1973 \\
75 \\
\text { Specimens } \\
\end{array}$ & $\begin{array}{l}1974 \\
16 \\
\text { Specimens } \\
\end{array}$ & $\begin{array}{l}1973-74 \\
\text { Combined } \\
31 \\
\text { Specimens } \\
\end{array}$ & $\begin{array}{l}\text { Consol Test } \\
\text { Pit } 1974- \\
20 \\
\text { Specimens } \\
\end{array}$ \\
\hline $\begin{array}{l}\text { Insects: } \\
\text { Grasshoppers (ORTHOPTERA) } \\
\text { Beetles (COLEOPTERA) } \\
\text { Misce } 17 \text { aneous }\end{array}$ & $\begin{array}{l}171 / \\
1 \\
1\end{array}$ & $\begin{array}{l}11 / \\
- \\
-\end{array}$ & $\begin{array}{l}1] 1 / \\
1 \\
1\end{array}$ & $\begin{array}{l}11] \\
- \\
-\end{array}$ \\
\hline $\begin{array}{l}\text { Grasses: } \\
\text { Stipa comata } \\
\text { Agropyron aristata } \\
\text { Agropyron spicatum } \\
\text { Agropyron spp. } \\
\text { Dactylis glomerata } \\
\text { Poa spp. } \\
\text { Unknown Grasses }\end{array}$ & $\begin{array}{l}10 \\
- \\
- \\
20 \\
10 \\
15\end{array}$ & $\begin{array}{r}12 \\
\overline{8} \\
10 \\
\overline{15} \\
20\end{array}$ & $\begin{array}{r}11 \\
\overline{4} \\
15 \\
\overline{13} \\
18\end{array}$ & $\begin{array}{r}2 \\
10 \\
2 \\
8 \\
8 \\
20 \\
4 \\
15\end{array}$ \\
\hline $\begin{array}{l}\text { Forbs: } \\
\text { Melilotus spp. } \\
\text { Rosa spp. } \\
\text { Taraxicum spp. } \\
\text { Artemisia spp. } \\
\text { Legumes } \\
\text { Unknown Forbs }\end{array}$ & $\begin{array}{r}10 \\
5 \\
5 \\
5 \\
5 \\
5\end{array}$ & $\begin{array}{l}5 \\
5 \\
6 \\
5 \\
2 \\
8\end{array}$ & $\begin{array}{l}8 \\
5 \\
5 \\
5 \\
3 \\
6\end{array}$ & $\begin{array}{l}5 \\
1 \\
- \\
2 \\
- \\
5\end{array}$ \\
\hline $\begin{array}{l}\text { Miscel laneous: } \\
\text { Hair } \\
\text { Bait }\end{array}$ & $\begin{array}{l}5 \\
1\end{array}$ & $\begin{array}{l}6 \\
4\end{array}$ & $\begin{array}{l}5 \\
3\end{array}$ & $\begin{array}{l}8 \\
5\end{array}$ \\
\hline $\begin{array}{l}\text { Unidentified Material: } \\
\text { I/ Percent volume of ident }\end{array}$ & $\frac{5}{a b 7 e \text { mat }}$ & $\frac{1}{a T \text { in } s}$ & 3 & 12 \\
\hline
\end{tabular}


Table 33. Use of four soil types by nongame mammals on Consol's test pit during winter.

\begin{tabular}{|c|c|c|c|c|}
\hline Habitat Type & $\begin{array}{c}\text { Winter } \\
72-73 \\
10 \text { Visits } \\
\end{array}$ & $\begin{array}{c}\text { Winter } \\
73-74 \\
7 \text { Visits } \\
\end{array}$ & $\begin{array}{l}\text { Winter } \\
74-75 \\
7 \text { Visits } \\
\end{array}$ & $\begin{array}{c}\text { A11 Winters } \\
\text { Combined } \\
24 \text { Visits } \\
\end{array}$ \\
\hline $\begin{array}{l}\text { Topsoiled: } \\
\text { WT Jackrabbit } \\
\text { Coyote } \\
\text { Deer Mice } \\
\text { Pocket Gophers } \\
\text { Meadow Voles } \\
\text { Cottontail Rabbit }\end{array}$ & $\begin{array}{l}251 / \\
3 \\
8 \\
- \\
- \\
-\end{array}$ & $\begin{array}{r}- \\
30 \\
3 \\
6 \\
- \\
-\end{array}$ & $\begin{array}{r}40 \\
30 \\
30 \\
6\end{array}$ & $\begin{array}{r}17 \\
28 \\
16 \\
2 \\
14 \\
2\end{array}$ \\
\hline $\begin{array}{l}\text { Sha Te: } \\
\text { WT Jackrabbit } \\
\text { Coyote } \\
\text { Deer Mice }\end{array}$ & $\begin{array}{l}3 \\
7 \\
-\end{array}$ & $\begin{array}{l}- \\
-\end{array}$ & $\begin{array}{r}- \\
10\end{array}$ & $\begin{array}{r}2 \\
10 \\
1\end{array}$ \\
\hline $\begin{array}{l}\text { Sandstone-Shale: } \\
\text { WT Jackrabbit } \\
\text { Coyote } \\
\text { Deer Mice } \\
\text { Cottontail Rabbit }\end{array}$ & $\begin{array}{l}3 \\
- \\
-\end{array}$ & $\begin{array}{r}18 \\
- \\
-\end{array}$ & $\begin{array}{r}10 \\
2 \\
4\end{array}$ & $\begin{array}{r}2 \\
11 \\
1 \\
2\end{array}$ \\
\hline $\begin{array}{l}\text { Sandstone: } \\
\text { WT Jackrabbit } \\
\text { Coyote } \\
\text { Deer Mice } \\
\text { Meadow Voles } \\
\text { Bobcat } \\
\text { Bushy-tailed Woodrat } \\
\text { Richardson Ground Squirrel } \\
\text { Yellow-bellied Marmot } \\
\text { Cottontail Rabbit }\end{array}$ & $\begin{array}{r}10 \\
9 \\
6 \\
- \\
- \\
- \\
- \\
- \\
-\end{array}$ & $\begin{array}{r}- \\
23 \\
14 \\
- \\
2 \\
2 \\
- \\
- \\
-\end{array}$ & $\begin{array}{r}- \\
20 \\
16 \\
14 \\
- \\
\overline{1} \\
1 \\
2\end{array}$ & $\begin{array}{r}4 \\
15 \\
11 \\
6 \\
1 \\
1 \\
1 \\
1 \\
1\end{array}$ \\
\hline $\begin{array}{l}\text { 1/ Frequency of use among th } \\
\text { tracks among numbered are }\end{array}$ & $\begin{array}{l}6 \text { areas in } \\
\text { within a sc }\end{array}$ & $\begin{array}{l}\text { Figure } 12 \\
\text { if mixture }\end{array}$ & percent & urrence of \\
\hline
\end{tabular}




\section{Square Deal Pit}

Our objectives at the Square Deal Pit, similar to those at Consol's test pit, were to gain data concerning establishment of vegetational cover and use of the area by wildlife. During stripping operations, topsoil was removed and stockpiled. After the coal was removed and the area backfilled and graded, topsoil was placed over the entire disturbed area during winter 1973-74. Prior to seeding during late February 1974. manure was applied to the entire area. The area was driti seeded sometime during the late winter-early spring period in 1974. Species seeded on the site included western wheatgrass, slender wheatgrass, green needlegrass, and yellow sweetclover, among others.

Vegetational Analysis

Three permanent vegetational analysis sites were established and read during July 1974: one at the bottom of the slope, one at mid-slope and one near the top. Each was analyzed by the method described previously. Data from the three sites were averaged and appear in Table 34.

Forbs and grasses exhibited a canopy of 24 and 20 percent, respectively during 1974. Annual forbs, which included Russian thistle as well as another member of the goosefoot family (CHENOPODIACEAE), occurred on all three sites. Yellow sweetclover was the only biennial or perennial forb to occur on all three sites. Other forbs that occurred on the area are 1isted in Table 34. Western wheatgrass and other wheatgrasses (Agropyron spp.) were the only grasses observed during the first growing season. No native shrubs were observed in the plots during July 1974.

Table 34. Constancy, canopy coverage and frequency of low-growing vegetation on a gently sloping southeast exposure as determined by examination of $202 \times 5$ decimeter plots on each of three sites at the Square Deal Mine.

Taxa

GRASSES:

Agropyron smithii Agropyron spp.

Total Grasses

FORBS :

Atriplex spp. CHENOPODIACEAE

Lappula redowski $i$

Medicago sativa

Melizotus officinalis

Salsola kali

Unidentified Forbs

Total Forbs

Bare Ground

Rock
3 Topsoiled Sites

$100 / 13 / 921 /$

$100 / 10 / 73$

$100 / 20 / 700$
$67 / 1 / 12$
$100 / 4 / 17$
$33 / \mathrm{tr} / 2$
33/4/ 23
$100 / 8 / 77$
$100 / 9 / 23$
$67 / \mathrm{tr} / 52 /$
$100 / 24 / 98$

$100 / 2 / 12$

area covered)/frequency (percent occurrence among plots)

$2 / \mathrm{tr}$ - trace (a value less than .5 percent) 
Use by Nongame Manmals

The area encompassed by Square Deal's strip mine was surveyed for nongame mammal activity since 1971. Census lines shown in Figure 14 were trapped to determine deer mouse populations. Census lines $A$ and $E$ were located on the undisturbed perimeter north and west of the mine area (Figure 14). From the years 1971 to 1974, these lines exhibited population indices of deer mice comparable to those reported for Musselshel1 County (McCann 1974). The remaining three census lines were located on disturbed portions. No deer mice were trapped in these areas in 1972 and 1973 during mining. The population census of 1 ines $B, C$ and $D$ during June 1974 indicated that deer mice were located on disturbed areas in lesser numbers than perimeter populations (Figure 15). These populations were $1+]$ and $7 \pm 1$ respectively.

\section{Nongame Mammal Inventory}

Nongame mammal data have been gathered in the research area since 1970 . Nineteen sites (Appendix Figure 17) were trapped during the 1973-74 report period. Methods and population formulas were described in previous reports (Dusek and McCann 1973 and 1974).

Deer Mouse

\section{Population Study}

Population indices for deer mice were reported by McCann (1974) for Musselshell County, Montana. The population appeared to stabilize at 4 mice per 1,000 linear feet since 1972. Trap data obtained during this report period indicated a slight increase of 4 to 6 mice per 1,000 linear feet (Figure 16). This increase was perhaps the result of increased reproductive additions to the population. Davis (1953) has reported that reproduction has an additive effect on population numbers, while mortality has a dampening effect.

\section{Habitat Preference}

The method of determining vegetation use by deer mice was presented in a previous report (Dusek and McCann 1974). Preferences for specific plant communities by both deer mice and meadow voles were indicated (Table 35).

Sites where only deer mice were trapped during 1973 and 1974 contained an average of 57 percent bare ground. The highest percentage of bare ground recorded on any one site was 83 percent, and the lowest was 48 percent. The percentages of lying litter and standing litter were 17 percent and 9 percent, respectively, for both years. Thus, deer mice appeared to occupy sites which have an open vegetational canopy containing small amounts of litter. Deer mice and meadow voles were both trapped on sites where bare ground averaged 22 percent (Dusek and McCann 1974). 
祭

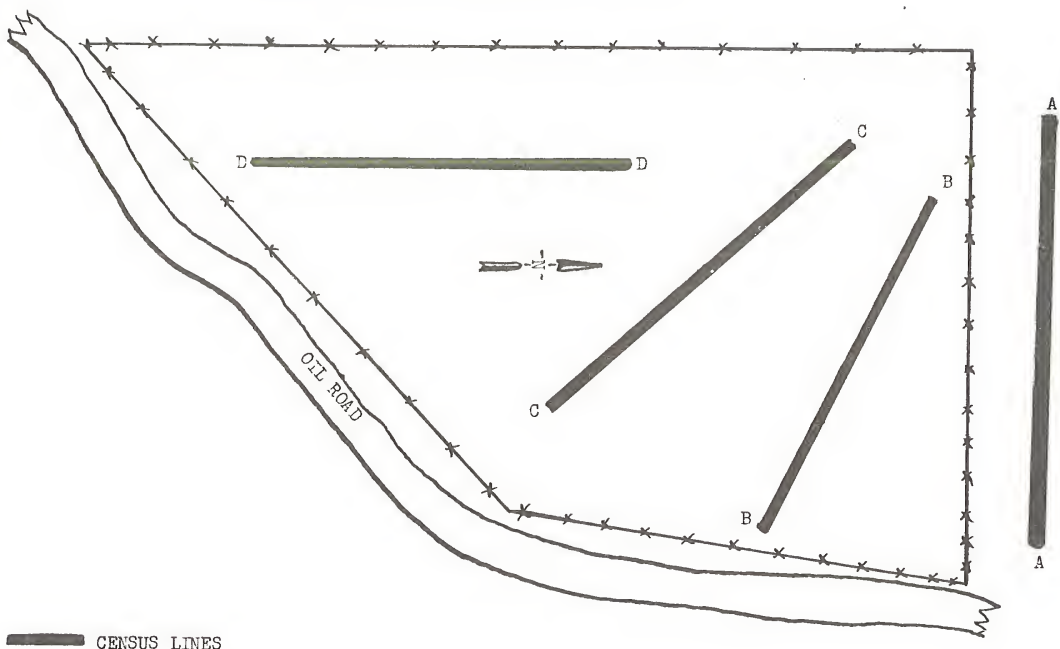

Figure 14. Census lines at the Square Deal Mine (lettered). 

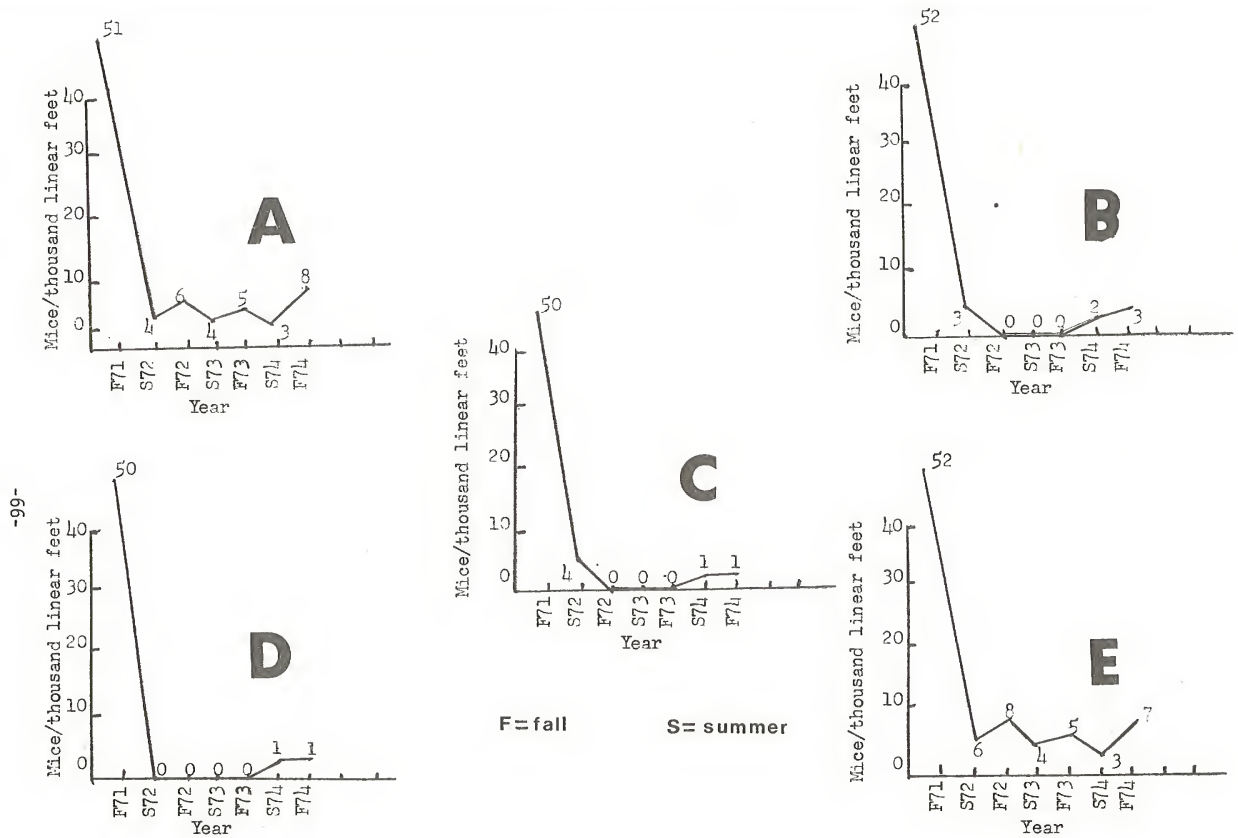

$$
F=\text { fall }
$$

$\mathrm{S}=$ summer

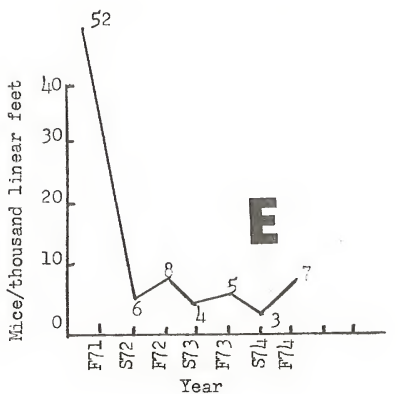

Figure 15. Deer mouse population trends at the Square Deal Mine. 
Table 35. Deer mouse and meadow vole synecological data.

\begin{tabular}{|c|c|c|c|c|c|c|c|}
\hline & $\begin{array}{c}\text { Deer Mouse } \\
1973 \\
7 \text { Sites } \\
\end{array}$ & $\begin{array}{c}\text { Deer Mouse } \\
1974 \\
7 \text { Sites } \\
\end{array}$ & $\begin{array}{l}\text { Combined } \\
\text { Deer Mouse } \\
1973-74 \\
14 \text { Sites } \\
\end{array}$ & $\begin{array}{l}\text { Deer Mouse } \\
\text { and } \\
\text { Meadow Vole } \\
2 \text { Sites } \\
\end{array}$ & $\begin{array}{c}\text { Meadow Vole } \\
1973 \\
4 \text { Sites } \\
\end{array}$ & $\begin{array}{c}\text { Meadow Vole } \\
1974 \\
4 \text { Sites } \\
\end{array}$ & $\begin{array}{c}\text { Combined } \\
\text { Meadow Vole } \\
1973-74 \\
8 \text { Sites } \\
\end{array}$ \\
\hline Bare Ground & $100 / 651 /$ & $100 / 50$ & $100 / 57$ & $100 / 22$ & 74/11 & $72 / 1$ & $73 / 6$ \\
\hline Grasses & $96 / 30$ & $99 / 32$ & $97 / 31$ & $100 / 72$ & $74 / 51$ & $100 / 67$ & $87 / 59$ \\
\hline Forbs & $81 / 13$ & $78 / 18$ & $80 / 15$ & $83 / 38$ & $60 / 14$ & $100 / 65$ & $80 / 40$ \\
\hline Shrubs & $13 / 17$ & $68 / 14$ & $40 / 16$ & $8 / 5$ & $19 / 11$ & 15/ 3 & $17 / 7$ \\
\hline Rock & $37 / 1$ & $35 / 3$ & $36 / 2$ & - & - & - & - \\
\hline Lichen & $43 / 3$ & $53 / 3$ & $48 / 3$ & - & $18 / 1$ & - & $9 / 1$ \\
\hline Lying Litter & $100 / 13$ & $98 / 20$ & $99 / 17$ & $100 / 79$ & $76 / 56$ & $100 / 80$ & $88 / 68$ \\
\hline Standing Litter & $99 / 7$ & $80 / 10$ & $90 / 9$ & $100 / 13$ & $75 / 30$ & $100 / 32$ & $88 / 31$ \\
\hline
\end{tabular}

1/ Percent frequency among plots/percent canopy coverage 
Food Habits

The stomach contents of 14 specimens of deer mice were analyzed during this report period. Methods of examination were described in a previous report (Dusek and McCann 1974). By volume, grasshoppers and other insects were the most abundant items in the diet throughout the year (Table 30).

\section{Meadow Voles}

General information and ecology of this animal have been presented in previous reports (Dusek and McCann 1973 and 1974).

\section{Habitat Preference}

Voles were trapped on 4 sites during this report period. The percentage of bare ground averaged 1 percent. When data from both 1973 and 1974 were averaged, an average of 6 percent bare ground was obtained (Table 35). This indicated that meadow voles preferred areas of dense vegetation. Sixty-eight and 37 percent lying and standing litter, respectively, occurred on these sites (Table 34).

\section{Food Habits}

The stomach contents of 16 meadow voles were analyzed during the report period. Methods and procedures have been explained in previous reports (Dusek and McCann 1974). Table 32 presents the summary of food contents by volume. For the years 1973 and 1974 grasses and forbs were the main food items utilized.

\section{Coyotes}

Methods of determining coyote (Conis latrans) food habits have been described in a previous report (Dusek and McCann 1974). During the report period, 118 specimens were examined. Food utilization is shown in Table 36. A total of 134 animals was examined during the previous and current report periods. Cottontail rabbits and deer mice were a major source of food of the specimens examined. Vegetation was used occasionally, as was carrion. Age determinations are in the process of examination.

\section{Red Fox}

Distribution and habitat use of the red fox (Vulpes fulva) were discussed in a previous report (Dusek and McCann 1974). During this report period, 38 specimens were examined. Although red foxes utilized a variety of food items, meadow voles appeared to be the most frequently used winter food item of specimens collected in the Bull Mountains (Table 37).

Forty-seven specimens were sexed and weighed during 1973 and 1974 . Females weighed less than males -12 pounds and 14 pounds, respectively (Appendix Table 41). 
Table 36. Coyote stomach analys is in Musselshel1 County during the winters of 1973-74 and $1974-75$.

\begin{tabular}{|c|c|c|c|}
\hline Stomach Contents & $\begin{array}{c}1973-74 \\
16 \\
\text { Specimens } \\
\end{array}$ & $\begin{array}{r}1974-75 \\
118 \\
\text { Specimens } \\
\end{array}$ & $\begin{array}{l}\text { Combined } \\
1973-75,134 \\
\text { Specimens }\end{array}$ \\
\hline \multicolumn{4}{|l|}{ Rabbits: } \\
\hline Cottontai1s (Sylvilagus spp.) & $251 /$ & 16 & 17 \\
\hline Jackrabbits (Lepus spp.) & - & 4 & 4 \\
\hline \multicolumn{4}{|l|}{ Rodents: } \\
\hline Deer Mice (Peroymyscus spp.) & 13 & 23 & 22 \\
\hline Meadow Voles (Microtus spp.) & 7 & $\begin{array}{l}5 \\
3\end{array}$ & $\begin{array}{l}5 \\
3\end{array}$ \\
\hline $\begin{array}{l}\text { Northern Pocket Gopher (Thomomys spp.) } \\
\text { Ord's Kangaroo Rat (Dipodomys spp.) }\end{array}$ & - & $\begin{array}{l}3 \\
3\end{array}$ & $\begin{array}{l}3 \\
3\end{array}$ \\
\hline Black-tailed Prairie Dog (Cynomys spp.) & - & 1 & 7 \\
\hline House Mice (Mus spp.) & - & 2 & 2 \\
\hline Bushy-tailed Woodrat (Neotoma spp.) & - & 1 & 1 \\
\hline \multicolumn{4}{|l|}{ Birds: } \\
\hline Pheasant (Phasianus spp.) & 1 & 7 & 7 \\
\hline Passerines & 1 & 7 & 7 \\
\hline Unknown Quil7s & 1 & 1 & 1 \\
\hline \multicolumn{4}{|l|}{ PT ant Foods: } \\
\hline Barley & - & 2 & 2 \\
\hline Stipa comata & - & 2 & 2 \\
\hline Agropyron spp. & 7 & 2 & 3 \\
\hline Agropyron spicatrom & - & 1 & 1 \\
\hline Rose hips (Rosa spp.) & - & 2 & 2 \\
\hline Sagebrush (Artemisia spp.) & - & 1 & 1 \\
\hline Unknown Grasses & $\bar{z}$ & 1 & 7 \\
\hline Twigs and Stems & 7 & 17 & 16 \\
\hline Leaves & 7 & $\overline{7}$ & 2 \\
\hline Commercial Feed & - & 1 & 1 \\
\hline Chokecherry & - & 2 & 2 \\
\hline \multicolumn{4}{|l|}{ Carrion: } \\
\hline Hereford Cattie & - & 7 & 7 \\
\hline Angus Cattle & $\overline{7}$ & 1 & 1 \\
\hline $\begin{array}{l}\text { Unknown Cow (Bovus spp.) } \\
\text { Mule Deer (odocoileus hemionus) }\end{array}$ & $\begin{array}{l}7 \\
7\end{array}$ & $\begin{array}{l}2 \\
2\end{array}$ & $\begin{array}{l}2 \\
2\end{array}$ \\
\hline \multicolumn{4}{|l|}{ Other Mammals: } \\
\hline Mule Deer (Odocoileus hemionus) & - & 5 & 5 \\
\hline Domestic Sheep & - & 3 & 3 \\
\hline Skunk (Mephitis spp.) & $\bar{z}$ & 1 & 1 \\
\hline Raccoon (Procyon spp.) & 7 & - & 1 \\
\hline
\end{tabular}


Table 36 continued. Coyote stomach analysis in Musselshell County during the winters of 1973-74 and 1974-75.

\begin{tabular}{|c|c|c|c|}
\hline Stomach Contents & $\begin{array}{c}1973-74 \\
16 \\
\text { Specimens } \\
\end{array}$ & $\begin{array}{c}1974-75 \\
118 \\
\text { Specimens } \\
\end{array}$ & $\begin{array}{l}\text { Combined } \\
1973-75,134 \\
\text { Specimens }\end{array}$ \\
\hline $\begin{array}{l}\text { Insects: } \\
\text { Crickets } \\
\text { Beetles } \\
\text { Maggots } \\
\text { Grasshoppers }\end{array}$ & $\begin{array}{l}- \\
- \\
-\end{array}$ & $\begin{array}{l}1 \\
1 \\
1 \\
2\end{array}$ & $\begin{array}{l}1 \\
1 \\
1 \\
2\end{array}$ \\
\hline $\begin{array}{l}\text { Miscel laneous: } \\
\text { Bone Fragments } \\
\text { Bait } \\
\text { Dirt } \\
\text { Stones } \\
\text { Lead Shot }\end{array}$ & $\begin{array}{r}7 \\
7 \\
44 \\
25 \\
13\end{array}$ & $\begin{array}{r}1 \\
6 \\
10 \\
4 \\
2\end{array}$ & $\begin{array}{r}1 \\
6 \\
13 \\
7 \\
3\end{array}$ \\
\hline $\begin{array}{l}\text { Nematodes: } \\
\text { Roundworms (PYSALOPTERA) }\end{array}$ & 38 & 30 & 32 \\
\hline Empty: & 25 & 31 & 33 \\
\hline
\end{tabular}


Table 37. Red fox stomach analys is in the Bull Mountains area during winter.

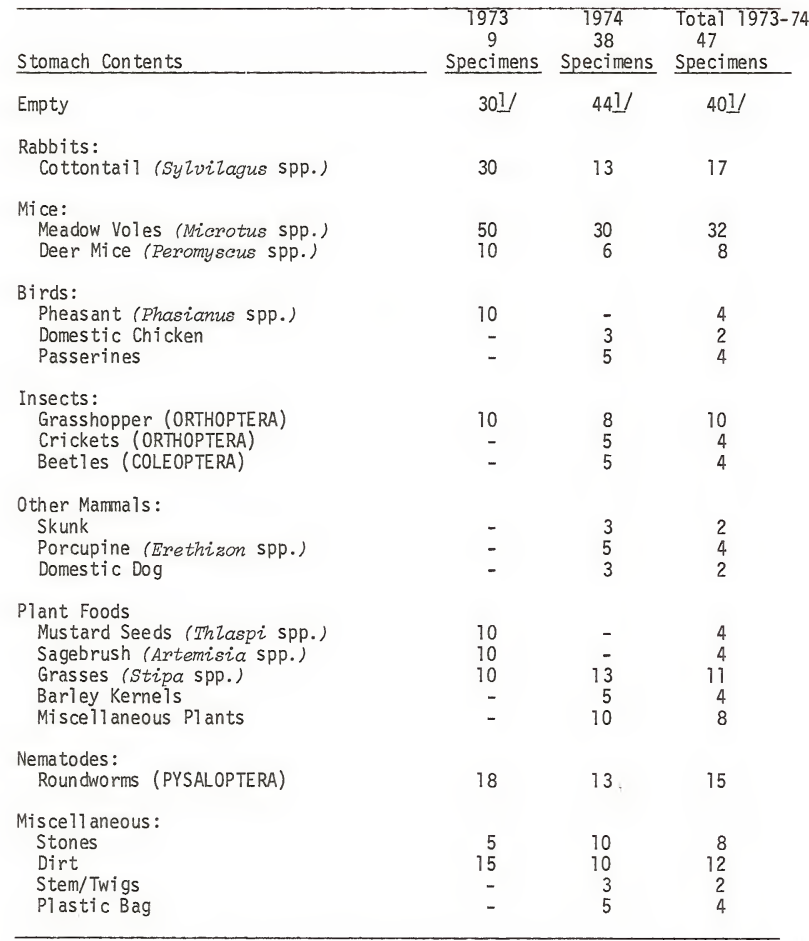

1/ Percent frequency of occurrence among stomachs 


\section{Raccoon}

Twenty-three specimens of raccoons (Procyon Lotor) were analyzed during the winter of 1974 for stomach contents, sex, weight and embryo scars. Grasshoppers and barley seed occurred in the diet most frequently during the report period (Table 38). These findings were similar to those reported during the previous year (Dusek and McCann 1974). Weights of 36 specimens from both report periods averaged 17 pounds for males and 18 pounds for females (Appendix Table 42).

\section{Bobcat}

During the report period, nine bobcats (Lynx mufus) were analyzed. Males weighed more than females - 22 pounds and 17 pounds, respectively (Appendix Table 42). Stomach contents of those animals examined indicated that rabbits and rodents are the mainstay of the winter diet (Table 39).

\section{Badger}

Twelve badgers (Taxidea taxus) were examined, weighed and sexed during this report period. Appendix Table 44 indicates sex ratios and embryo scar counts. Stomach analyses on these specimens indicated that mice and ground squirrels were the principal winter diet (Table 40).

\section{SUMMARY AND DISCUSSION}

Included in the following synopsis are observations and tentative conclusions resulting from the third year of research:

1. As discussed in previous reports (Dusek and McCann 1973 and 1974) surface overlying the Mammoth-Rehder coal seam provides important habitat for mule deer, elk and Merriam's turkey. The greatest occurrence of antelope in the area lies to the south and east of that coal seam.

2. Although nearly all vegetation types received at least some use by mule deer, elk and turkeys, the grassland type received the greatest average yearlong use by all three species. That type, especially the grassland park subtype, exhibited a wide variety of grasses, forbs and shrubs (Dusek and McCann 1974).

The agricultural type received considerable use by mule deer and elk during spring, summer and fall of 1974. Use of that type by those two species was minimal during winter. It is the writer's opinion that turkeys were not observed in the agricultural type during fal1 1974 and winter 1974-75 due to an abundant crop of pine seeds in and near timbered types. When available, pine seeds are preferred over other food items (Jonas 1966).

Although numerous observations of the three game species were made in the ponderosa pine-grassland type throughout the year, the physical nature of that type imposed a definite observability bias. The actual proportion of mule deer, elk and turkeys observed in that type during periods of activity was perhaps underestimated. The ponderosa pine-bunchgrass subtype does provide an abundant quantity and variety of forage when compared to other types (Dusek and McCann 1974). Timbered types also provide 
Table 38. Raccoon stomach analys is in the Bull Mountains area during winter.

\begin{tabular}{|c|c|c|c|}
\hline Stomach Contents & $\begin{array}{r}1973 \\
13 \\
\text { Specimens } \\
\end{array}$ & $\begin{array}{r}1974 \\
23 \\
\text { Specimens } \\
\end{array}$ & $\begin{array}{l}\text { 1973-74 } \\
\text { Combined, } \\
\text { Specimens }\end{array}$ \\
\hline Empty & $401 /$ & $351 /$ & $361 /$ \\
\hline $\begin{array}{l}\text { Rabbits: } \\
\quad \text { Cottontail (Syzvizagus spp.) }\end{array}$ & 8 & 7 & 8 \\
\hline $\begin{array}{l}\text { Mice: } \\
\text { Meadow Yoles (Microtus spp.) } \\
\text { Deer Mice (Peromyscus spp.) }\end{array}$ & $\begin{array}{l}15 \\
15\end{array}$ & $\begin{array}{l}4 \\
4\end{array}$ & $\begin{array}{l}8 \\
8\end{array}$ \\
\hline $\begin{array}{l}\text { Birds: } \\
\text { Pheasant (Phasianus spp.) } \\
\text { Passerines }\end{array}$ & $\begin{array}{l}8 \\
-\end{array}$ & $\overline{4}$ & $\begin{array}{l}3 \\
3\end{array}$ \\
\hline $\begin{array}{l}\text { Insects: } \\
\text { Grasshoppers (ORTHOPTERA) } \\
\text { Beet1es (COLEOPTERA) } \\
\text { Water Insects }\end{array}$ & $\begin{array}{r}10 \\
8 \\
11\end{array}$ & $\begin{array}{r}30 \\
4 \\
-\end{array}$ & $\begin{array}{r}22 \\
8 \\
8\end{array}$ \\
\hline $\begin{array}{l}\text { Plant Foods: } \\
\text { Barley Seeds } \\
\text { Rose Hips } \\
\text { Wild Plum } \\
\text { Grasses } \\
\text { Mustard Seeds } \\
\text { Stems/Twigs }\end{array}$ & $\begin{array}{r}23 \\
15 \\
8 \\
8 \\
- \\
10\end{array}$ & $\begin{array}{r}48 \\
4 \\
- \\
8 \\
4 \\
8\end{array}$ & $\begin{array}{r}39 \\
8 \\
3 \\
8 \\
3 \\
11\end{array}$ \\
\hline $\begin{array}{l}\text { Nematodes: } \\
\text { Roundworms (PSYALOPTERA) }\end{array}$ & 8 & 13 & 11 \\
\hline $\begin{array}{l}\text { Miscellaneous: } \\
\text { Commercial Feed } \\
\text { Sand } \\
\text { Dirt } \\
\text { Hair }\end{array}$ & $\begin{array}{r}8 \\
8 \\
20 \\
15\end{array}$ & $\begin{array}{r}8 \\
26 \\
34\end{array}$ & $\begin{array}{r}8 \\
3 \\
25 \\
27\end{array}$ \\
\hline
\end{tabular}

I/ Percent frequency of occurrence among stomachs 
Table 39. Bobcat stomach analysis in the Bull Mountains area during winter.

\begin{tabular}{|c|c|c|c|}
\hline Stomach Contents & $\begin{array}{l}7973 \\
5 \\
\text { Specimens } \\
\end{array}$ & $\begin{array}{l}1974 \\
9 \\
\text { Specimens } \\
\end{array}$ & $\begin{array}{l}1973-74 \\
\text { Combined, } 14 \\
\text { Specimens } \\
\end{array}$ \\
\hline Empty & - & 33 ll & 21 II \\
\hline $\begin{array}{l}\text { Rabbits: } \\
\text { Cottontail (Syzvizagus spp.) }\end{array}$ & 100 & 11 & 42 \\
\hline $\begin{array}{l}\text { Mice: } \\
\text { Meadow Voles (Microtus spp.) } \\
\text { Deer Mice (Peromyscus spp.) }\end{array}$ & $\begin{array}{r}100 \\
20\end{array}$ & $\begin{array}{l}33 \\
11\end{array}$ & $\begin{array}{l}57 \\
14\end{array}$ \\
\hline $\begin{array}{l}\text { Plant Foods: } \\
\text { Twigs/Stems }\end{array}$ & 20 & 33 & 28 \\
\hline $\begin{array}{l}\text { Other Manmals: } \\
\text { Porcupine (Erethizon spp.) }\end{array}$ & 20 & - & 7 \\
\hline $\begin{array}{l}\text { Nematodes: } \\
\text { Roundworms (PSYALOPTERA) }\end{array}$ & 20 & 11 & 14 \\
\hline $\begin{array}{l}\text { Miscellaneous: } \\
\text { Unknown Feathers } \\
\text { Plastic Sack } \\
\text { Dirt } \\
\text { Sand } \\
\text { Bobcat Fur }\end{array}$ & $\begin{array}{l}20 \\
20 \\
20 \\
20 \\
-\end{array}$ & $\begin{array}{c}- \\
\overline{3} \\
\overline{33}\end{array}$ & $\begin{array}{r}7 \\
7 \\
28 \\
7 \\
21\end{array}$ \\
\hline
\end{tabular}

1/ Percent frequency of occurrence among stomachs 
Table 40. Badger stomach analysis in the Bull Mountains area during winter.

\begin{tabular}{|c|c|c|c|}
\hline Stomach Contents & $\begin{array}{l}1973 \\
5 \\
\text { Specimens } \\
\end{array}$ & $\begin{array}{l}1974 \\
12 \\
\text { Specimens } \\
\end{array}$ & $\begin{array}{l}1973-74 \\
\text { Combined, } 17 \\
\text { Specimens } \\
\end{array}$ \\
\hline Empty & $401 /$ & $751 /$ & 65 ㄴ \\
\hline $\begin{array}{l}\text { Mice: } \\
\text { Deer Mice (Peromyscus spp.) } \\
\text { Meadow Voles (Microtus spp.) }\end{array}$ & $\begin{array}{r}60 \\
-\end{array}$ & $\begin{array}{r}16 \\
8\end{array}$ & $\begin{array}{r}29 \\
5\end{array}$ \\
\hline $\begin{array}{l}\text { Ground Squirrels: } \\
\text { Richardson's Ground Squirrel } \\
\text { (Citelzus spp.) }\end{array}$ & 20 & 16 & 18 \\
\hline $\begin{array}{l}\text { Prairie Dogs: } \\
\text { Black-tailed Prairie Dog } \\
\text { (Cynomys spp.) }\end{array}$ & 20 & 8 & 12 \\
\hline $\begin{array}{l}\text { Miscellaneous: } \\
\text { Sand } \\
\text { Stems/Twigs } \\
\text { Maggots } \\
\text { Unknown Material }\end{array}$ & $\begin{array}{r}20 \\
20 \\
- \\
-\end{array}$ & $\begin{array}{r}50 \\
\overline{8} \\
8\end{array}$ & $\begin{array}{r}41 \\
6 \\
6 \\
6\end{array}$ \\
\hline $\begin{array}{l}\text { Nema todes: } \\
\text { Roundworms (PSYALOPTERA) }\end{array}$ & 30 & 25 & 29 \\
\hline
\end{tabular}

1/ Percent frequency of occurrence among stomachs 
escape cover. At least 70 percent of the observations of each of the three species were observed in or within 300 feet of the nearest stand of timber.

Mule deer used the sagebrush-grassland type to a greater extent than did elk or turkeys. The greatest use of that type, primarily the silver sagebrush-grassland subtype, occurred during winter 1974-75, which is understandable, since silver sagebrush was the major item in the diet of mule deer during winter. However, shrubs other than sagebrush rarely occurred in this vegetation type (Dusek and McCann 1974) and deer must still use other types to obtain a variety of shrubs.

3. Based on relocations of individually marked animals, elk (adult females) exhibited a much greater mobility than did mule deer (adult females). This is based on the assumption that the data obtained from the small sample of marked animals was representative of adult females of each species. More data should be available before the next report is written.

Mean distances between observations as well as mean maximum distances between observations of adult cow elk were greatest during winter and least during summer. Similarly, the portion of the home ranges used during the winter-spring period was greater than that used during the summer-fall period. This general pattern was similar to that reported by Mackie (1970) for elk in the Missouri River breaks.

4. Mule deer fawn production has been 1ow since 1972. Data gathered during January and February 1972 indicated a higher fawn crop in 1971 (Dusek and McCann 1973) than occurred during the following 3 years. An annual increment (reflected by the percent of the population composed of juveniles) of 25 to 30 percent is believed to be required to maintain a stable population (Gordon et al. 1974). Estimated annual increments, based on fall observations, were 21,27 and 22 percent during 1972, 1973 and 1974, respectively.

During 1974, cow:calf ratios for elk of over 50:100 were reported for the second consecutive year. Increments, based on summer and fall observations combined, were 29 percent during both 1973 and 1974 . Since twinning is very rare in elk populations, perhaps some cows are breeding as yearlings (the second rutting season after birth) in order for the population to reflect a ratio of 50 or more calves per 100 cows. Cow elk normally breed for the first time during the third rutting season after birth (approximately 28 months) (Murie 1951). The elk population in the Bull Mountains may be increasing under present habitat conditions.

Turkey production, in terms of average brood sizes and young:adult female, has increased from 1972 to 1974. Young:adult has decreased during the same period, al though the annual increment has not been less than 50 percent during the 3 years.

5. At Consol's test pit, the total vegetational canopy increased on al1 soil types from 1972 to 1974, but the greatest increase was on topsoil. Crested wheatgrass exhibited the greatest increase in canopy among grasses, while others increased only slightly, remained approximately the same, or 
decreased. Al though the canopy of yellow sweetclover fluctuated between years, it was the most abundant forb during all three years. Occurrence of shrubs on the disturbed area was almost negligible. The revegetated test pit area did not compare favorably with native grasslands, either in abundance or diversity of plant species used by mule deer for forage (Dusek and McCann 1974). For example, the test pit provided an abundant quantity of yellow sweetclover during summer, but little else in the form of forbs and browse. Important shrubs in the winter diet, such as silver sagebrush and skunkbush, were absent on the disturbed site.

6. Deer mouse populations appeared to have stabilized at a much lower level since the population decline between 1971 and 1972. Even at the low population level, deer mice appeared to be an important item in the diet of predators, especially coyotes and badgers.

Population data for meadow voles in the Bull Mountains are lacking. This species appeared to be an important item in the diets of red fox and bobcats. 


\section{LITERATURE CITED}

Blair, W. F. 1940. Home ranges and populations of the meadow vole in southern Michigan. J. Wi1d1. Manage. 4:149-161.

Boeker, E. L. and V. E. Scott. 1969. Roost tree characteristics for Merriam's turkey. J. Wild1. Manage. 33(1):121-124.

Compton, H. 0. 1974. Upland game bird survey and inventory, Region 5. Comp. rept. Proj. No. W-130-R-5, Job No. II-5. 77 pp.

Coop, K. J. 1971. Habitat use, distribution, movement and associated behavior of elk, Little Belt Mountains, Montana. M.S. Thesis, Mont. St. Univ., Bozeman. $61 \mathrm{pp}$.

Daubenmire, R. F. 1959. A canopy coverage method of vegetational analysis. N.W. Sci. 33(1):43-64.

Davis, D. E. 1953. The characteristics of rat populations. Quart. Rev. Biol. 28:373-401.

Day, T. A. 1973. Summer and fall elk distribution, movements and range use in the Little Belt Mountains. M.S. Thesis, Mont. St. Univ., Bozeman. $70 \mathrm{pp}$.

Dice, L. R. 1952. Natural communities. Univ. Michigan Press, Ann Arbor. $547 \mathrm{pp}$.

Dusek, G. L. and S. A. McCann. 1973. Bull Mountains coal field study. Mont. Dept. of Fish and Game and Consolidation Coal Co., Prog. rept. $53 \mathrm{pp}$.

. 1974. ButT Mountains coat field study. Mont. Dept. of Fish and Game and Consolidation Coal Co., Prog. rept. 76 pp.

Getz, L. L. 1961. Home ranges, territoriality and movement of the meadow voles. J. Mamm. 42(1):24-26.

Gordon, F. A., K. J. Coop and J. W. Denton. 1974. Big game survey and inventory, Region 5. Comp. rept., Proj. No. W-130-R-5, Job No. I-5. $87 \mathrm{pp}$.

Hayne, D. W. 1949. Calculation of size of home ranges. J. Mamm. $30(1): 1-18$.

Hormay, A. L. 1970. Principles of rest-rotation grazing and multiple use 7 and management. U. S. Dept. of Int. Bul1. 26 pp.

Ingles, L. G. 1967. Mammals of the Pacific states. Stanford Univ. Press, Stanford. $506 \mathrm{pp}$.

Johnson, D. R. and R. M. Hansen. 1969. Effects of range treatment with 2,4-D on rodent populations. J. Wild7. Manage. 33(1):125-132. 
Jonas, R. 1966. Merriam's turkey in southeastern Montana. Mont. Dept. of Fish and Game, Tech. Bu11. No. 3. 36 pp.

MacDonald, D. and R. A. Jantzen. 1967. Management of the Merriam's turkey. The wild turkey and its management. The Wildl. Soc. 493-534.

Mackie, R. J. 1970. Range ecology and relations of mule deer, elk and cattle in the Missouri River breaks. Wild1. Monog. No. 20. 77 pp.

Martin, P. R. 1975. Sarpy basin wildlife ecology study. Mont. Dept. of Fish and Game and Cormorant Corp. Prog. rept. 58 pp.

Martinka, C. J. 1969. Population ecology of summer resident elk in Jackson Hole, Wyoming. J. Wild7. Manage. 33(3):465-481.

Maser, C. and R. M. Storm. 1970. A key to Microtinae of the Pacific northwest. Oregon St. Univ., Corvallis. 162 pp.

McCann, S. A. 1974. A four-year population study of Peromyscus maniculatus in Musselshell County, Montana. Mont. Acad. of Sci. $34: 37-42$.

1975a. Home ranges of meadow voles and deer mice on a rectamation test pit in eastern Montana. Mont. Acad. of Sci. (Pub.)

. 1975b. The movement and occurrence of small mammals on a reclamation plot. Fort Union Coal Field Symposium. (Pub.)

Murie, 0. J. 1951. The elk of North America. Stackpole Co., Harrisburg, Pa. and The Wildl. Manage. Inst., Washington, D.C. 376 pp.

Neff, D. J. 1968. The pellet-group count technique for big game trend, census and distribution: a review. J. Wild1. Manage. 32(3):597-614.

Stoneberg, R. P. 1973. Beartooth-Absaroka wildlife-mining research: planning inventory, game. Prog. rept., Proj. No. FW-2-R-1 and 2, Job No. 1-a. $17 \mathrm{pp}$.

U. S. Dept. of Commerce. 1972-75. Climatological data with comparative data for Roundup, Montana.

Vertz, B. J. 1959. Notes on the ecology of mammals of a stripmined area in southern Illinois. Trans. Illinois Acad. of Sci. 52:134-139.

Wambolt, C. L. 1973. Range grazing systems for resource conservation and greater production. Co-op Ext. Ser., Mont. St. Univ., Bozeman. Bul1. 340 .

Williams, 0. 1955. Home ranges of Peromyscus maniculatus rufinus in Colorado ponderosa pine community. J. Mamm. 36(1)42-45. 
APPENDIX

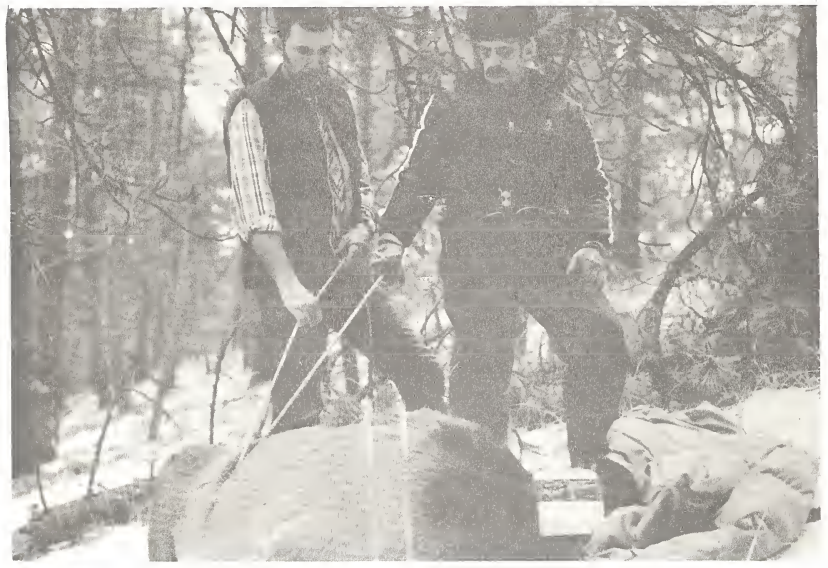


Table 41. Red fox specimen data - Bull Mountains area.

1973:

Sample size - 9 specimens

Average weight of 7 adult males - 10 carcass pounds

Average weight of 2 adult females - 11 carcass pounds

Average embryo scars of females - 2 scars

1974:

Sample size - 38 specimens

Average weight of 21 adult males - 15 carcass pounds

Average weight of 17 adult females - 12 carcass pounds

Average embryo scars of females - 2 scars

1973-74 Combined:

Sample size - 47 specimens

Average weight of 28 adult males - 14 carcass pounds

Average weight of 19 adult females - 12 carcass pounds

Average embryo scars of females - 2 scars

Table 42. Raccoon specimen data - Bull Mountains area.

1973:

Sample size - 13 specimens

Average weight of 9 adult males - 20 carcass pounds

Average weight of 4 adult females - 21 carcass pounds

Average number of embryo scars in females - 2 scars

1974:

Sample size - 23 specimens

Average weight of 19 adult males - 16 carcass pounds

Average weight of 4 adult females - 16 carcass pounds

Average number of embryo scars in females -2 scars

1973-74 Combined:

Sample size - 36 specimens

Average weight of 28 adult males - 17 carcass pounds

Average weight of 8 adult females - 18 carcass pounds

Average number of embryo scars in females -2 scars 
Table 43. Bobcat specimen data - Bull Mountains area.

1973:

Sample size - 5 specimens

Average carcass weight of 3 adult males - 22 carcass pounds

Average carcass weight of 2 adult females - 15 carcass pounds

Average number of embryo scars in females - 2 scars

1974:

Sample size - 9 specimens

Average carcass weight of 1 adult male -22 carcass pounds

Average cracass weight of 8 adult females - 17 carcass pounds

Average number of embryo scars in females -2 scars

1973-74 Combined:

Sample size - 14 specimens

Average carcass weight of 4 adult males - 22 carcass pounds

Average carcass weight of 10 adult females - 16 carcass pounds

Average numier of embryo scars in females - 2 scars

Table 44. Badger specimen data - Bull Mountains area.

1973:

Sample size - 5 specimens

Average carcass weight of 2 adult males - 18 carcass pounds

Average carcass weight of 3 adult females - 13 carcass pounds

Average number of embryo scars in females -2 scars

1974:

Sample size - 12 specimens

Average carcass weight of 9 adult males - 16 carcass pounds

Average carcass weight of 3 adult females - 11 carcass pounds

Average number of embryo scars in females - 2 scars

1973-74 Combined:

Sample size - 17 specimens

Average carcass weight of 11 adult males - 17 carcass pounds

Average carcass weight of 6 adult females -12 carcass pounds

Average number of embryo scars in females - 2 scars 
Table 45. Frequency of occurrence of plant species in the habitats of deer mice and meadow voles in the Bull Mountains.

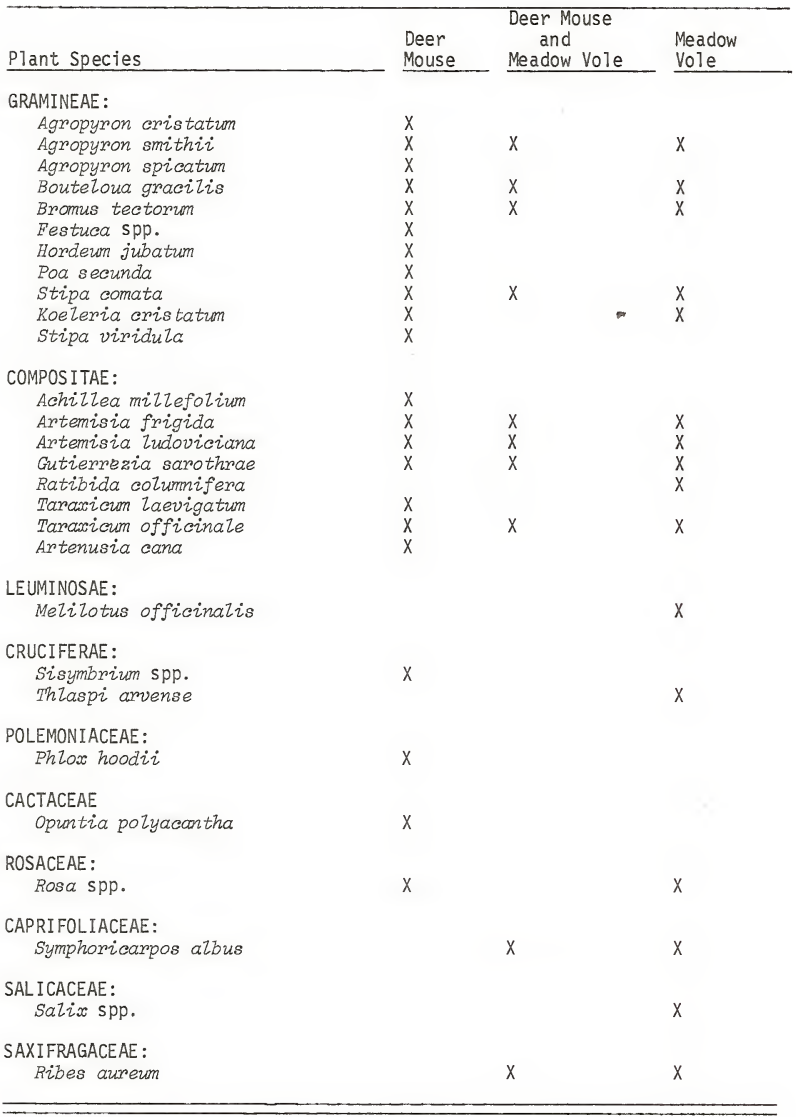




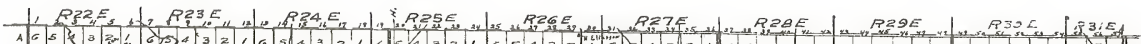

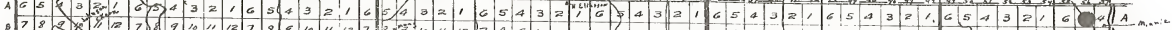

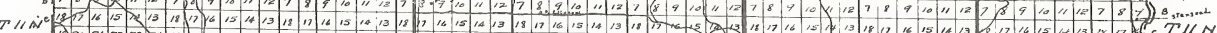

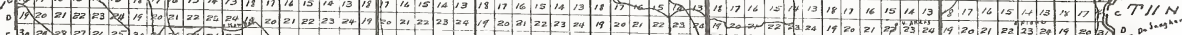

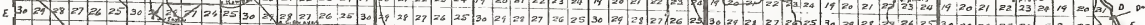

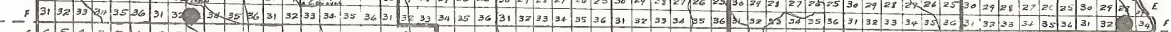

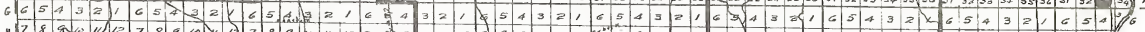

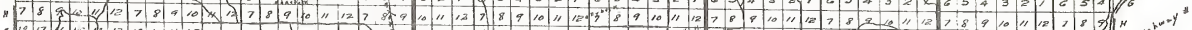

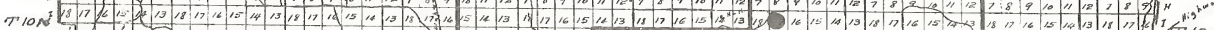

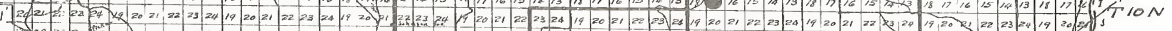

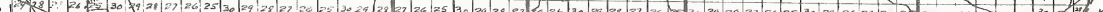

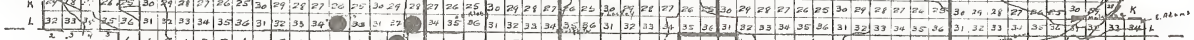

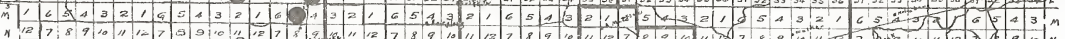

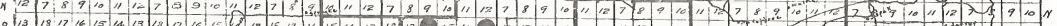

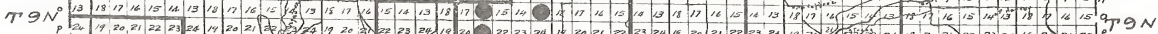

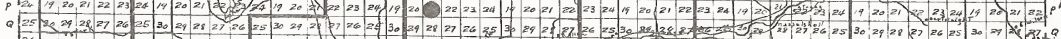

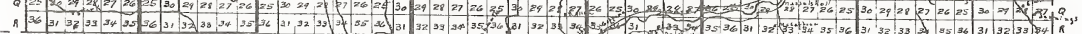

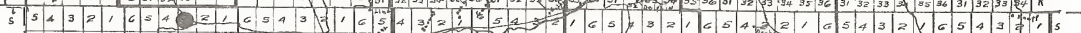

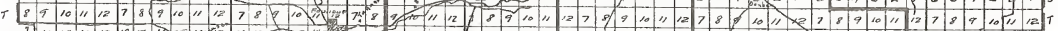

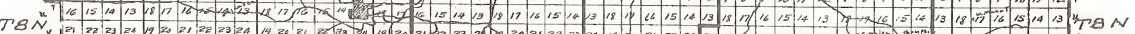
TSNV

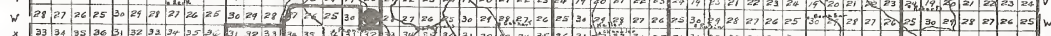

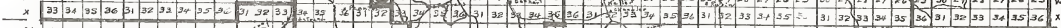

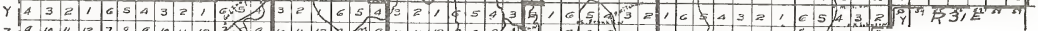

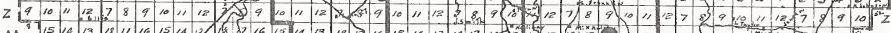

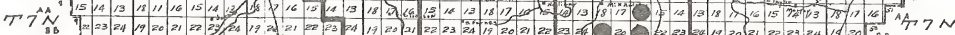
S

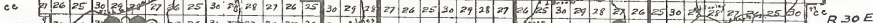

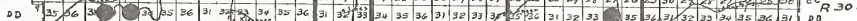

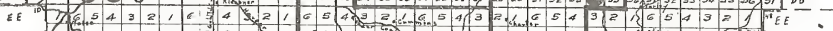

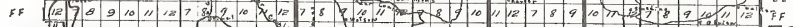

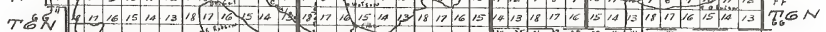
GI

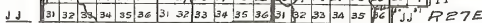

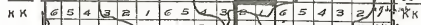

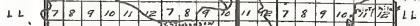

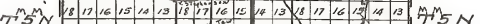

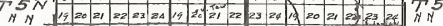

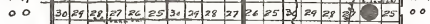

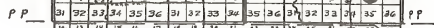

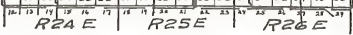

PREE PZSE

Mussels hell

Count y

Figure 17. 1974-75 TRAP SITE LOCATIONS 

